\title{
An Examination of Job Satisfaction Related to Generational Cohorts and Faculty Status of West Virginia University Extension Service County Faculty
}

\author{
Susan K. Gamble \\ West Virginia University
}

Follow this and additional works at: https://researchrepository.wvu.edu/etd

\author{
Recommended Citation \\ Gamble, Susan K., "An Examination of Job Satisfaction Related to Generational Cohorts and Faculty \\ Status of West Virginia University Extension Service County Faculty" (2014). Graduate Theses, \\ Dissertations, and Problem Reports. 124. \\ https://researchrepository.wvu.edu/etd/124
}

This Dissertation is protected by copyright and/or related rights. It has been brought to you by the The Research Repository @ WVU with permission from the rights-holder(s). You are free to use this Dissertation in any way that is permitted by the copyright and related rights legislation that applies to your use. For other uses you must obtain permission from the rights-holder(s) directly, unless additional rights are indicated by a Creative Commons license in the record and/ or on the work itself. This Dissertation has been accepted for inclusion in WVU Graduate Theses, Dissertations, and Problem Reports collection by an authorized administrator of The Research Repository @ WVU. For more information, please contact researchrepository@mail.wvu.edu. 
An Examination of Job Satisfaction

Related to Generational Cohorts and Faculty Status

of West Virginia University Extension Service County Faculty

Susan K. Gamble

Dissertation submitted

to the College of Education and Human Services

at West Virginia University

in partial fulfillment of the requirements for the degree of

Doctor of Education

in

Higher Education Administration

Ernest R. Goeres, Ph.D., Co-Chair

Lauryl A. Lefebvre, Ph.D., Co-Chair

Allison H. Nichols, Ed.D.

L. Christopher Plein, Ph.D.

Joy F. Saab, Ed.D.

Department of Curriculum and Instruction/ Literacy Studies

Morgantown, West Virginia

2014

Keywords: Job Satisfaction, Generational Cohort, Tenure Status, Extension Service Copyright 2014 Susan K. Gamble 


\begin{abstract}
An Examination of Job Satisfaction Related to Generational Cohorts and Faculty Status of West Virginia University Extension Service County Faculty
\end{abstract}

\title{
Susan K. Gamble
}

Retention of county Extension faculty has been identified as a significant challenge facing the Extension Service system across the country (ECOP LAC, 2005). There are several influences that contribute to employee turnover in the Extension Service, including: burnout, dissatisfaction with pay related to the amount of time worked, downsizing, long and abnormal work hours including nights and weekends, balancing work and family, and job stress (Boltes, Lippke, \& Gregory, 1995; Bradley, Driscoll, \& Bardon, 2012; ECOP LAC, 2005; Ensle, 2005; Fetsch \& Kennington, 1997; Kutilek, Conklin, \& Gunderson, 2002; Rousan \& Henderson, 1996). Within their positions, Extension personnel are required to fulfill a variety of roles including facilitator, negotiator, organizer, and primarily educator. Given the unique position descriptions and work assignments for county Extension faculty, there is a greater risk for job dissatisfaction.

This mixed-method study was completed with West Virginia University Extension Service county faculty. The study utilized document review of employment trend data at the West Virginia University Extension Service from the human resources department. An online questionnaire was implemented with county Extension faculty that included a modified Minnesota Satisfaction Questionnaire (MSQ) Short-Form, questions on perceptions of the work environment, and demographics. Interviews were also completed with supervisors on their perceptions and experiences of supervising county Extension faculty members. The study utilized the Herzberg Motivation-Hygiene Theory (1966) comparing intrinsic and extrinsic motivation factors and discusses the results and significance of corrections with independent variables, including faculty tenure status and generational cohort groups. Results showed that West Virginia University Extension county are satisfied or very satisfied with their job. The county Extension faculty were more intrinsically than extrinsically motivated, which according to the Herzberg Motivation-Hygiene Theory, leads to greater job satisfaction. There was a significant relation between job satisfaction and recognition, and job satisfaction and supervision. Generational cohort and tenure status were not found to be predictors of job satisfaction for West Virginia University Extension Service county faculty. Qualitative differences were found on intrinsic and extrinsic job satisfaction based on county Extension faculty long-answer questions and supervisor interviews.

The results of this study will create a better understanding of how Extension faculty are professionally motivated in their work. The study findings will assist the West Virginia University Extension Service system by providing empirical data that will indicate the job satisfaction level, and extrinsic and intrinsic work factors of county Extension faculty. Results could assist the organization in learning how to best serve its' employees by designing experiences that lead to improved employee satisfaction and an opportunity to reduce turnover. 


\section{ACKNOWLEDGEMENT}

Thank you to my husband Kent Gamble who has supported me throughout this long adventure. Without your care and encouragement this accomplishment would not have been possible. To my children Lewis, Clara, and Ellie, you have had to sacrifice so that I could complete this process. Thank you for always understanding when "mom has to write" and know that you can accomplishment whatever you set your mind to achieve.

Thank you to my co-chairs Dr. Goeres and Dr. Lefebvre for their guidance and wisdom through this journey. Dr. Nichols thank you for serving as the methodologist on my committee, and for helping me gain a better understanding of my quantitative research findings. Dr. Plein thank you for serving on my committee and as a mentor throughout my graduate studies. Dr. Saab thank you for serving on my committee, and also helping me secure my co-chairs so that the writing process could get underway. Also, thank you to Dr. Jaci Webb-Dempsey for serving as my qualitative research consultant and sharing your expertise of qualitative research.

I want to thank my classmates and friends who helped me survive the coursework, and encouraged and supported me through the writing process: our driving crew Kim, Gabbi, and Kristi, and Bea for the gracious food and hospitality each weekend. Also thank you Stacey Harper for reading various drafts, taking notes at my prospectus defense, and being there to listen and encourage me when I was not sure of the next steps. I also want to thank Sally Howard for graciously offering to serve as my proofreader.

My mom, Donna Cutlip, instilled in me the importance of education, setting goals, and always believing I could achieve this milestone. Thank you mom for all of the encouragement and sacrifices you made so that I could be where I am today. I also want to thank my grandparents Bill and Justine Cutlip whose love and support helped me achieve many accomplishments throughout my life. 


\section{TABLE OF CONTENTS}

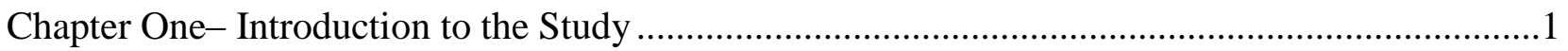

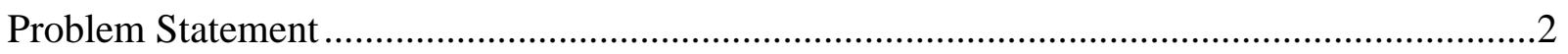

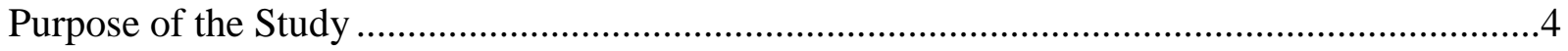

Research Questions ...............................................................................................

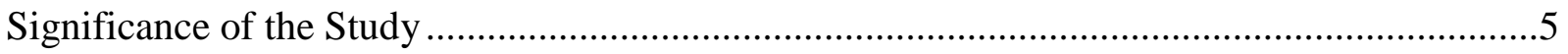

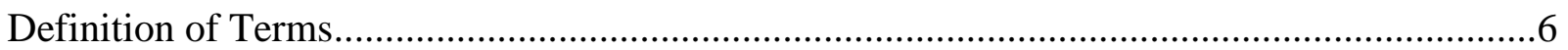

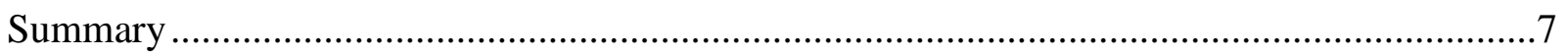

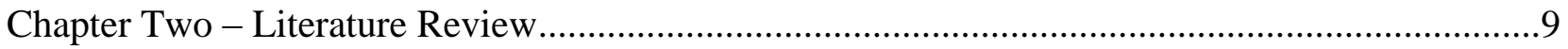

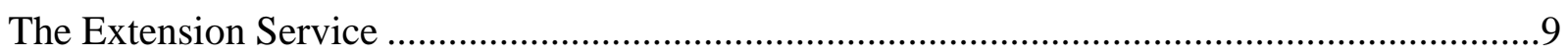

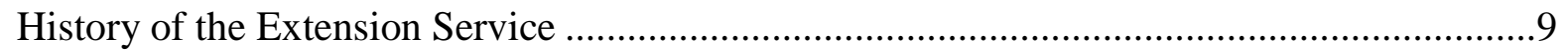

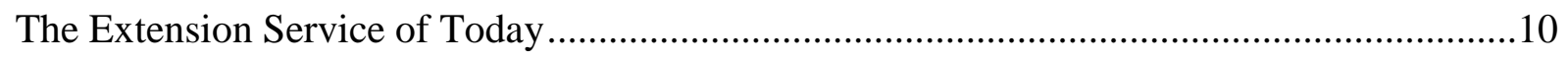

Land-Grant Institutions in West Virginia .............................................................. 11

Role of County Extension Faculty Member ................................................................ 12

County Extension Faculty Members at West Virginia University .....................................13

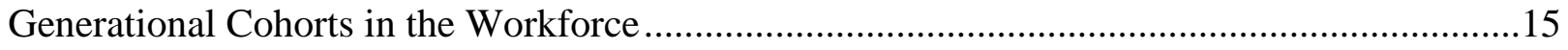

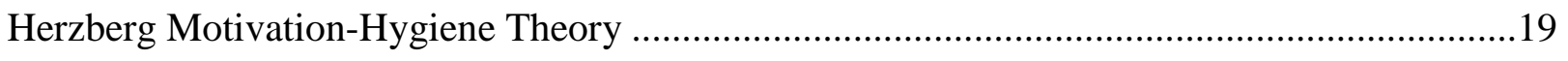

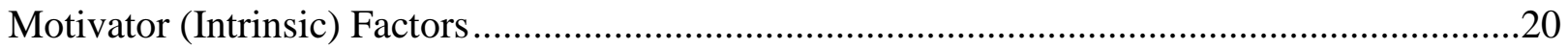

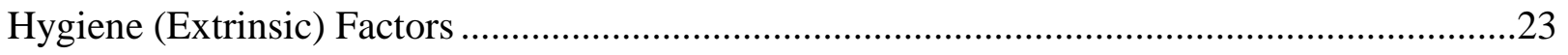

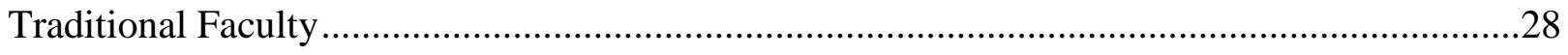

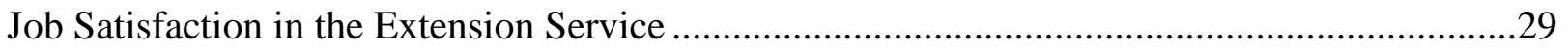

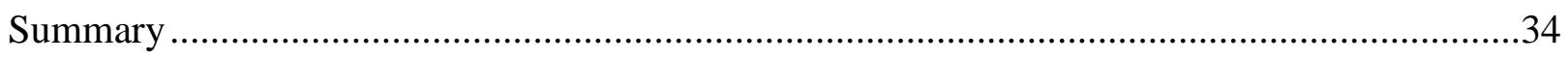

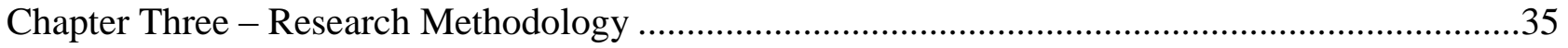




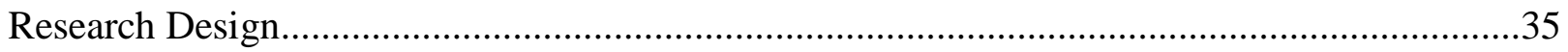

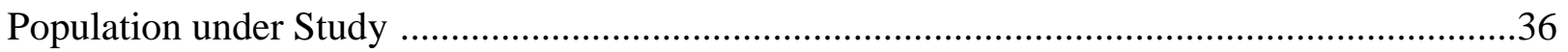

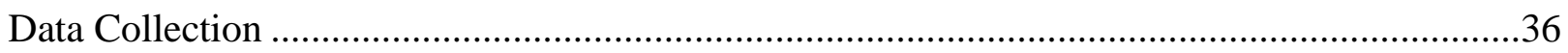

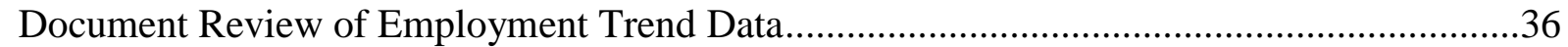

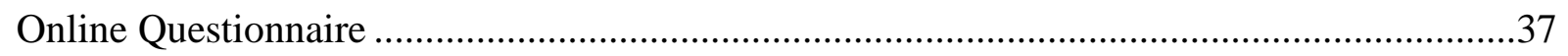

Interviews with Supervisors of County Extension Faculty .....................................................39

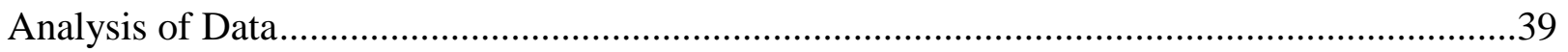

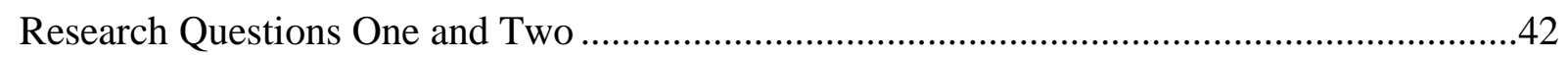

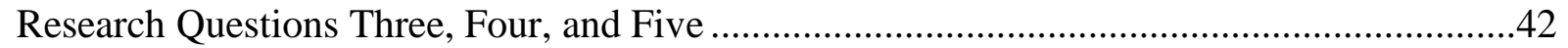

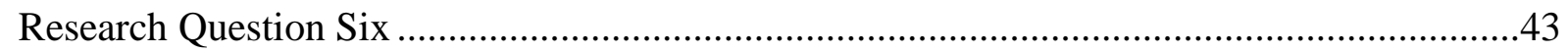

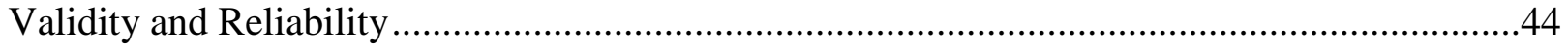

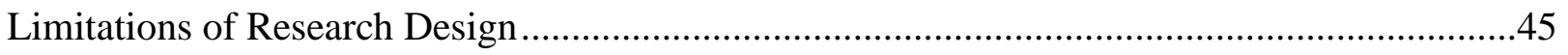

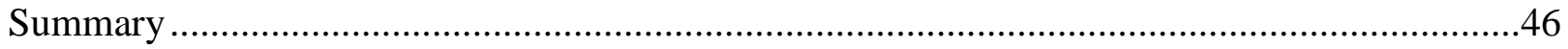

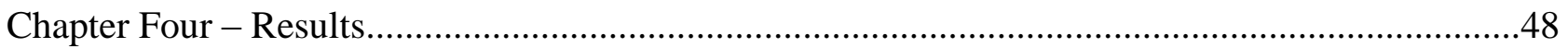

Research Question One: Demographic Profile ……………....................................................49

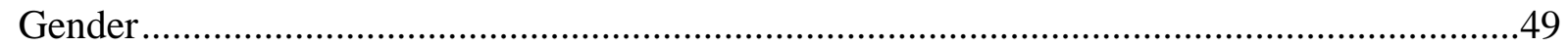

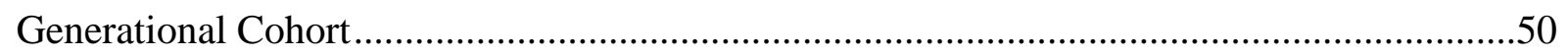

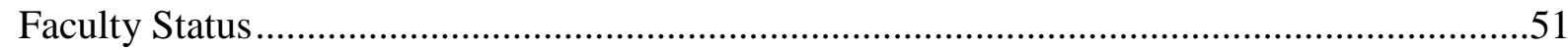

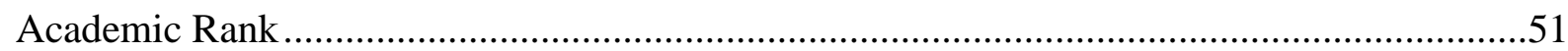

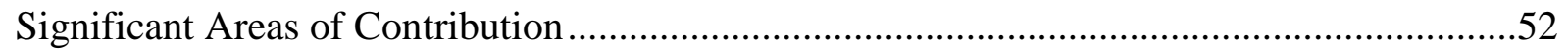

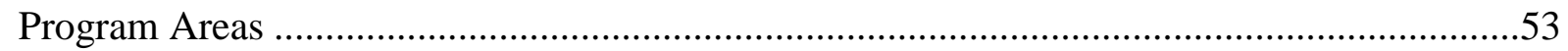

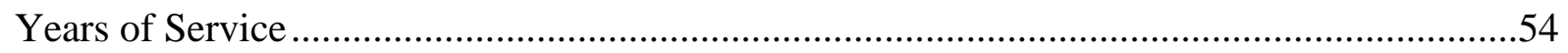

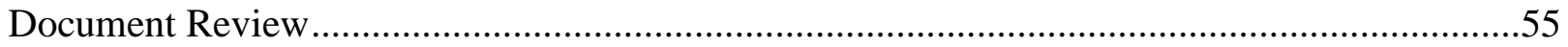


Research Question Two: Work Environment Profile ………….............................................55

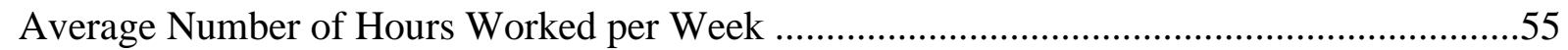

Average Number of Nights Away From Home per Year .......................................................56

Average Number of Direct Contacts per Year..........................................................................57

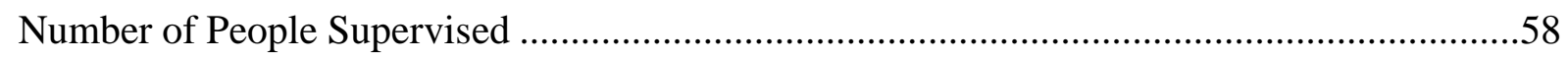

Percent of Time Spent Per Year on Teaching, Research, and Service ....................................59

Research Question Three: Overall Job Satisfaction................................................................61

Research Question Four: More Intrinsically or Extrinsically Motivated.....................................65

Research Question Five: Correlations between Job Satisfaction and Intrinsic/Extrinsic ...........67

Research Question Six: Differences between Generational Cohorts and Tenure Status ............69

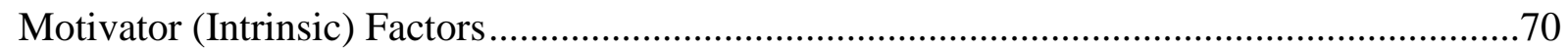

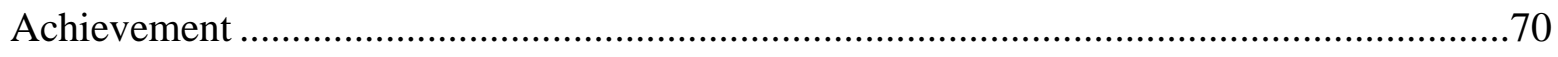

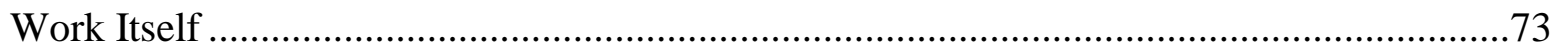

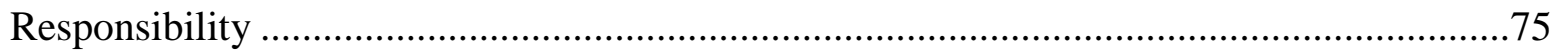

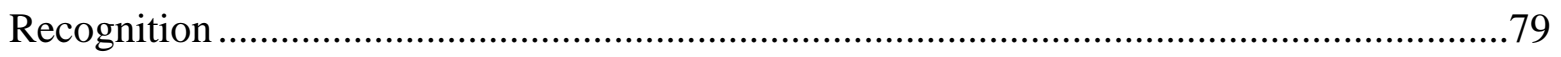

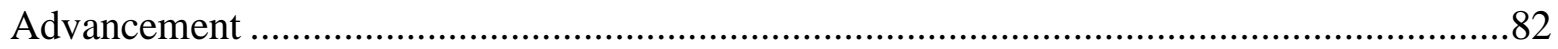

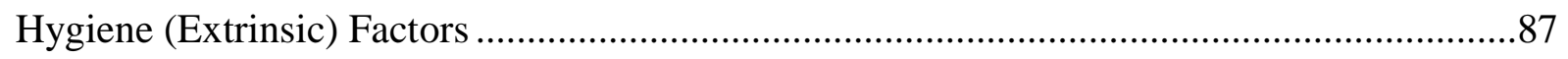

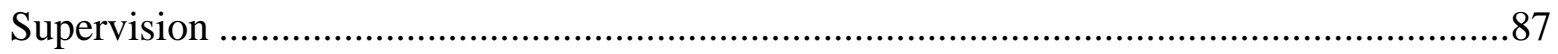

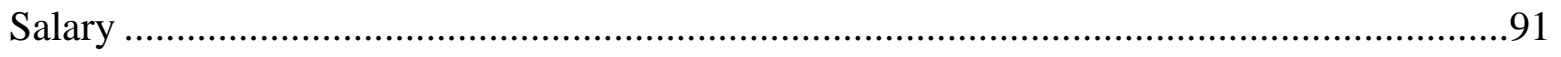

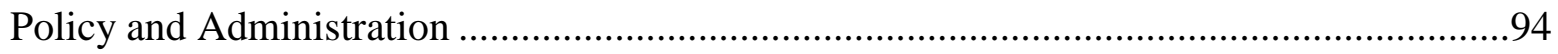

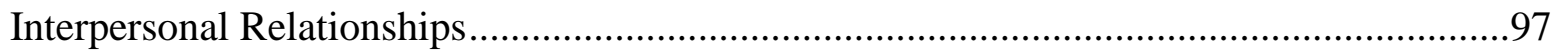

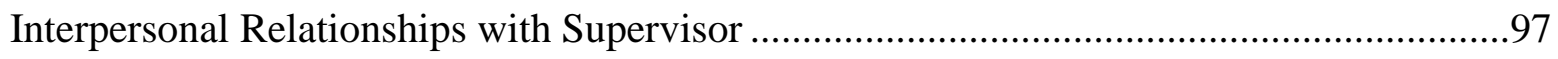

Interpersonal Relationships with Peer .............................................................................101 


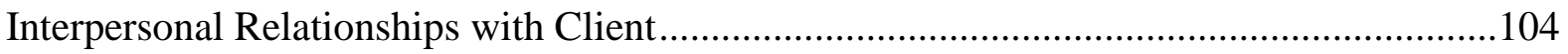

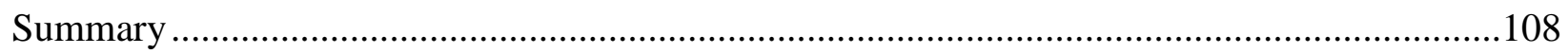

Chapter Five - Summary, Conclusions, and Recommendations ......................................................110

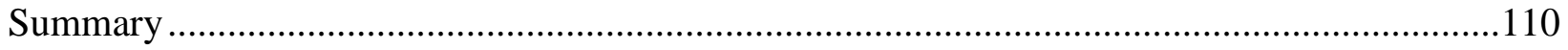

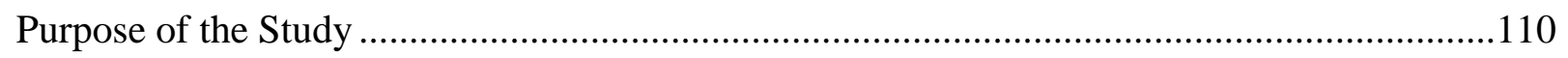

Research Questions ……………………………………............................................110

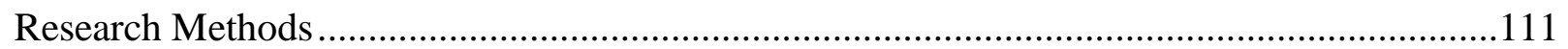

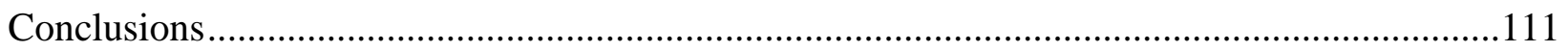

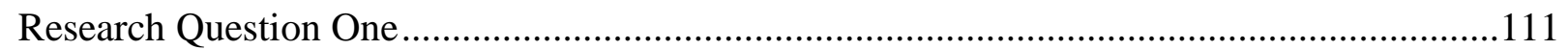

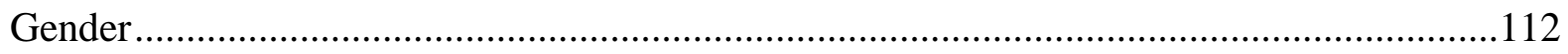

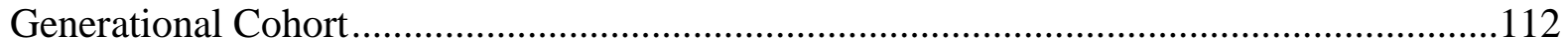

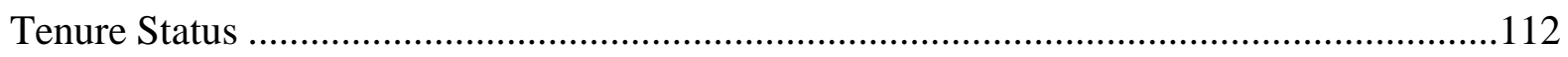

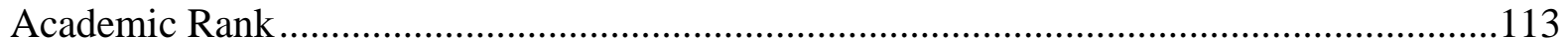

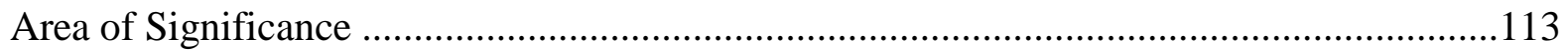

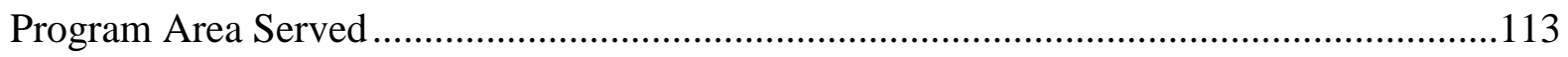

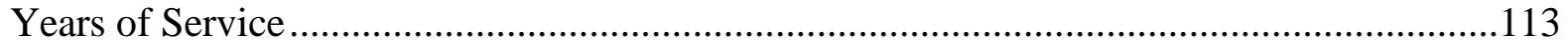

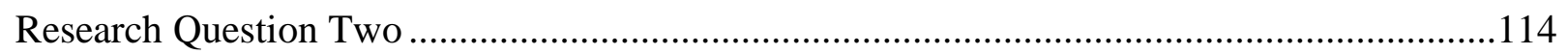

Average Number of Hours Worked a Week .........................................................................114

Number of Overnights Away From Home ………….........................................................114

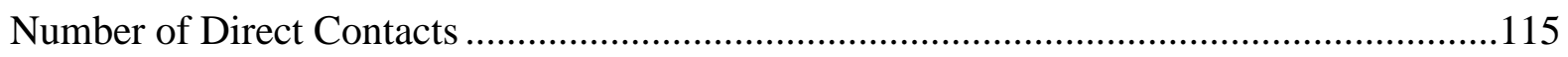

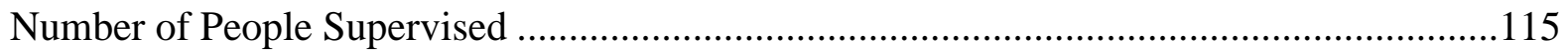

Percent of Time Spent on Teaching/Research/Service ......................................................115

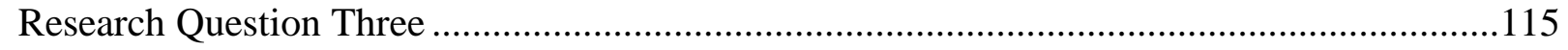




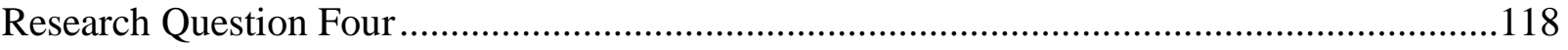

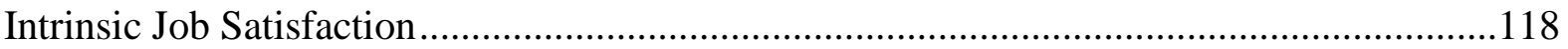

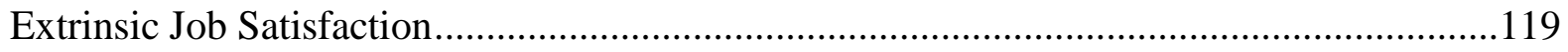

Generational Cohort/Tenure Status.............................................................................120

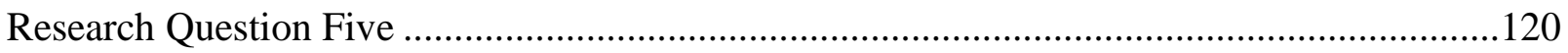

Research Question Six ...............................................................................................121

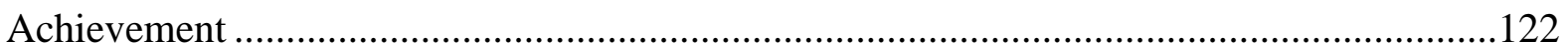

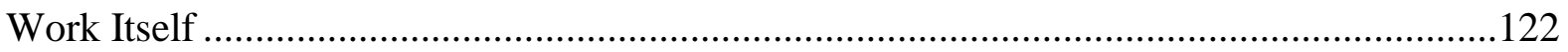

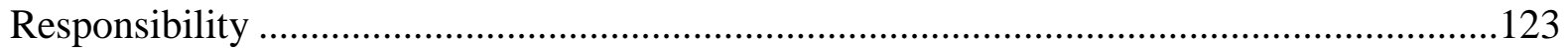

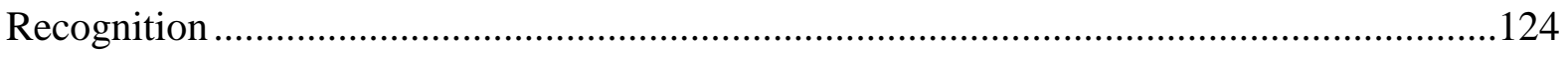

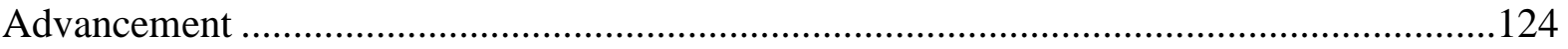

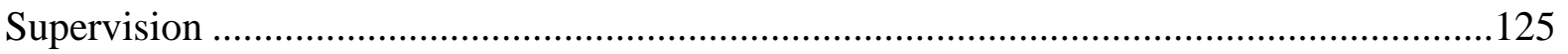

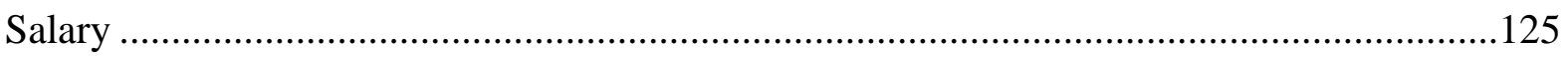

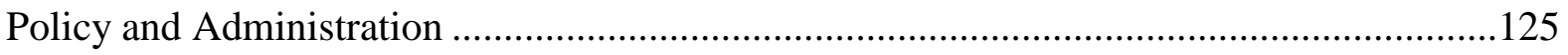

Interpersonal Relationships with Supervisor/Peer/Clients....................................................126

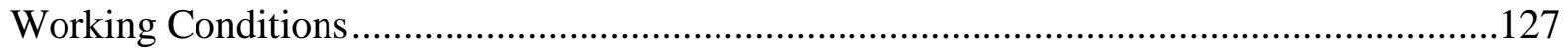

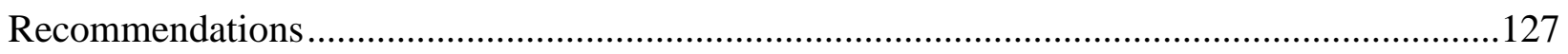

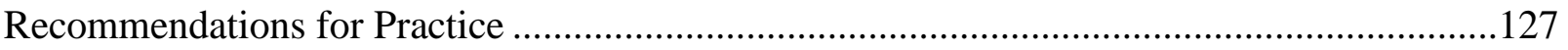

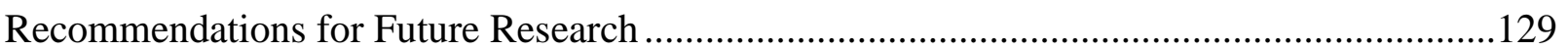

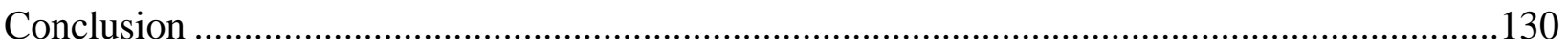

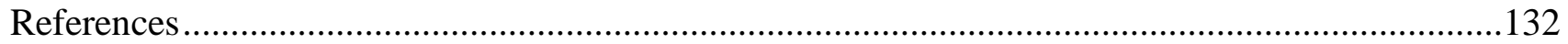




\section{LIST OF TABLES}

Table 1. Descriptions of Generations Currently in the Workforce ...........................................16

Table 2. MSQ Short-Form Questions by Intrinsic, Extrinsic, and Total Satisfaction .....................38

Table 3. Research Questions by Variables, Data Analysis Method, and Instrument Items ............40

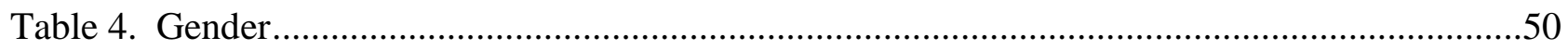

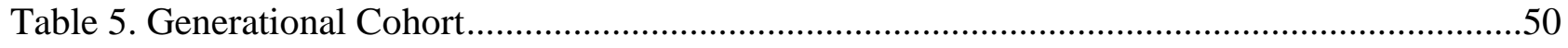

Table 6. Faculty Status: Tenure/Non-Tenure Status ............................................................51

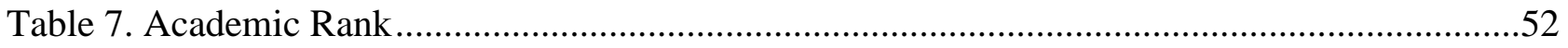

Table 8. Area of Significance in Addition to Teaching ......................................................53

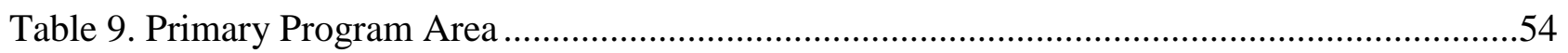

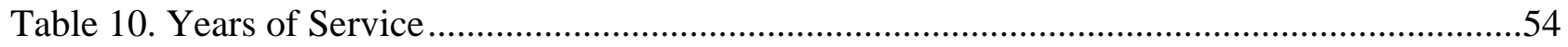

Table 11. Average Number of Hours Worked per Week ........................................................56

Table 12. Average Number of Nights Away From Home per Year ...............................................57

Table 13. Average Number of Direct Contacts per Year.........................................................58

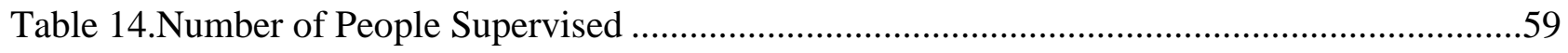

Table 15. Percent of Time Spent per Year on Teaching ...............................................................60

Table 16. Percent of Time Spent per Year on Research .......................................................60

Table 17. Percent of Time Spent per Year on Service .............................................................61

Table 18. MSQ Short-Form Means and Standard Deviations ...................................................61

Table 19. General Job Satisfaction Frequency Distribution ......................................................63

Table 20. Cross-Tabulation between General Job Satisfaction and Ordinal Descriptive Variables .64

Table 21. Regression Analysis between General Job Satisfaction and Ratio Variables .................65

Table 22. MSQ Short-Form Job Satisfaction Scores ..........................................................66

Table 23. Correlation between Intrinsic Satisfaction and General Satisfaction ............................68 
Table 24. Correlation between Extrinsic Satisfaction and General Satisfaction ............................69

Table 25. Seek New Responsibilities by Generational Cohort ....................................................76

Table 26. Seek New Responsibilities by Tenure Status .......................................................78

Table 27. Recognition Received Adequate for Work by Generational Cohort .............................8 80

Table 28. Recognition Received Adequate for Work by Tenure Status.....................................81

Table 29. Supervision Received Adequate by Generational Cohort ...........................................8

Table 30. Supervision Received Adequate by Tenure Status ..................................................90

Table 31. Salary Adequate by Generational Cohort ..............................................................92

Table 32. Salary Adequate by Tenure Status ...................................................................93 


\section{LIST OF FIGURES}

Figure 1. West Virginia University Extension Service Program Organizational Chart ..................13

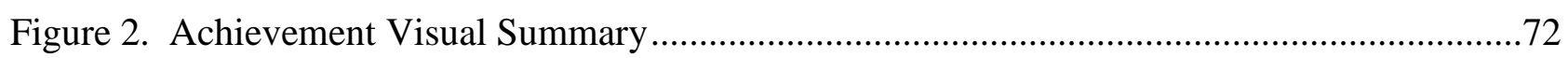

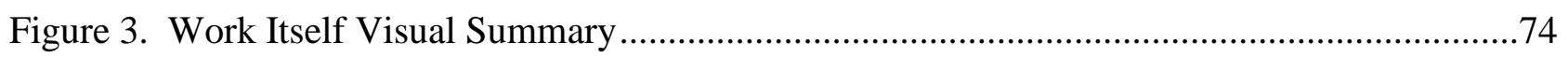

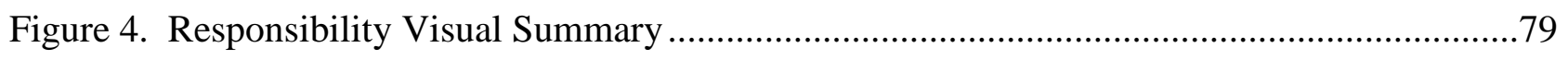

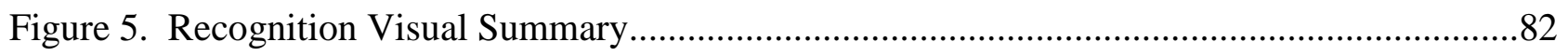

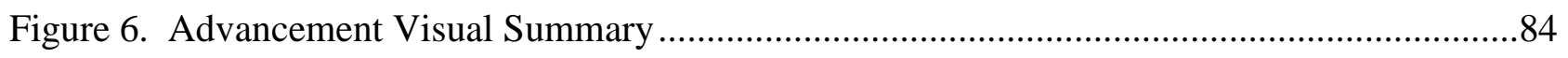

Figure 7. Supervision Visual Summary .................................................................... 91

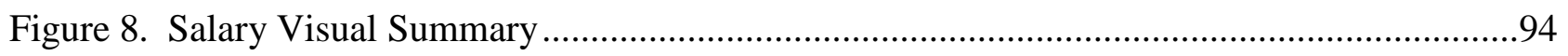

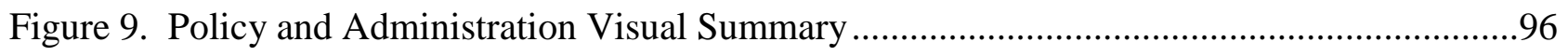

Figure 10. Interpersonal Relationships with Supervisor Visual Summary .................................100

Figure 11. Interpersonal Relationships with Peer Visual Summary .........................................103

Figure 12. Interpersonal Relationships with Client Visual Summary .......................................105

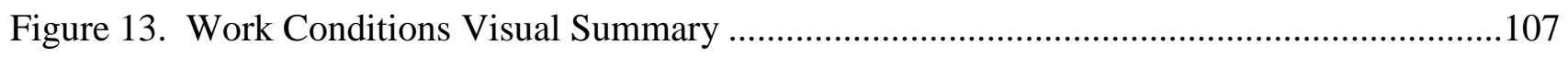




\section{$\underline{\text { LIST OF APPENDICES }}$}

APPENDIX A: Institutional Review Board Approval ............................................................141

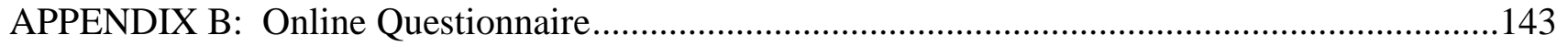

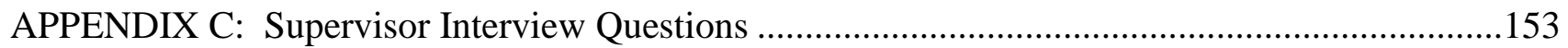

APPENDIX D: Permission to Use Minnesota Satisfaction Questionnaire (MSQ) Short-Form ......156

APPENDIX E: County-Based Faculty Cover Letter ..........................................................158

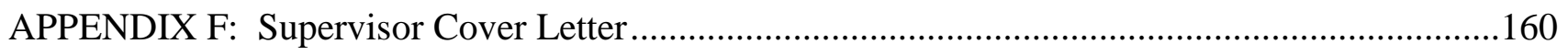

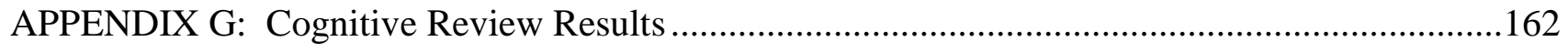

APPENDIX H: Qualitative Research Consultant Memo.........................................................166 


\section{Chapter One}

The Extension Service serves as the primary outreach component for postsecondary land grant institutions to a broader public. According to the United States Department of Agriculture (2011), through the Cooperative Extension Service, land-grant institutions put their research and teaching knowledge into action by working alongside the constituency to solve public needs with higher education resources. The Cooperative Extension Service is a partnership between the United States Department of Agriculture and local and state levels of government.

The Extension Service strives to educate people on how to apply knowledge acquired through the many academic disciplines of the land grant institution to assist individuals to solve problems, and support long-term development of youth, families, and communities (Patton, 1988). There are six major areas of focus: 4-H youth development, agriculture, leadership development, natural resources, family and consumer sciences, and community and economic development (United States Department of Agriculture, 2011).

The Extension Service currently faces a variety of new challenges since its creation in 1914. First, technology is changing at a fast rate, challenging Extension personnel to more quickly obtain and disseminate information to constituents. Second, demographics of the individuals being served by Extension have shifted as our society has become less agriculturally based. Third, there is increased competition for funding and resources as the Extension Service strives to show constituents and funders the organization is still relevant today. Fourth, is an increased knowledge base through accessibility of knowledge and increased interconnectedness (Cochran, Ferrari and Chen, 2012; ECOP LAC, 2010; Ladewig \& Rohs, 2000; Martenson, 2002).

To assist in addressing these challenges, the Extension Committee on Organization and Policy (ECOP) Leadership Advisory Council (LAC) (2010) identified that staffing patterns 
needed to be more trans-disciplinary and flexible and leadership must be able to manage change at any level. Specific committee recommendations included: 1) being more flexible in serving individuals with different backgrounds and needs, 2) strengthening and diversifying funding, 3) expanding and perfecting the methods of program delivery; and, 4) improving quality and skills of the Extension workforce.

\section{Problem Statement}

County Extension faculty retention has been identified as a significant challenge facing the Extension Service system across the country (ECOP LAC, 2005). Strong and Harder (2009) cite that Extension agents continue to leave the Extension system prematurely. Without a skilled and experienced workforce to address needed staffing patterns, the Extension system cannot be successful in reaching the organizational mission and goals. The success of Extension Service programs will be determined by the ability of the Extension system to retain qualified county Extension faculty (Cooper \& Graham, 2001).

There are several influences that contribute to employee turnover in the Extension Service. Reasons for turnover include: burnout, dissatisfaction with pay related to the amount of time worked, downsizing, long and abnormal work hours including nights and weekends, balancing work and family, and job stress (Boltes, Lippke, \& Gregory, 1995; Bradley, Driscoll, \& Bardon, 2012; ECOP LAC, 2005; Ensle, 2005; Fetsch \& Kennington, 1997; Kutilek, Conklin, \& Gunderson, 2002; Rousan \& Henderson, 1996). Ensle (2005) explains that job stress often occurs because Extension positions are multidimensional, requiring new projects to begin before old projects are completed. In addition, due to the Extension's complicated partnership between state and county governments, there are often conflicting expectations and personnel policies. Required work schedules include long and abnormal work hours including many nights and 
weekends (Strong \& Harder, 2009). Within their positions, Extension personnel are required to fulfill a variety of roles including facilitator, negotiator, organizer, and primarily educator.

Turnover is the ratio of the number of employees that had to be replaced in a given time period to the average number of employees. Turnover rates for the West Virginia University Extension Service of county-based faculty are an average of $10 \%$ each year (J. Momen, personal communication, March 25, 2013). Turnover of county Extension faculty can have a significant impact on the organization and the county. Turnover disrupts educational programming, leads to a loss of accumulated knowledge and a loss of relationships in the community, results in unmet citizen needs, creates low morale among the remaining Extension professionals, and wastes a variety of resources dedicated to faculty service trainings (Bradley et al., 2012; Safrit \& Owen, 2010). In addition, turnover at the county level can have a negative impact on an entire landgrant university system, costing the organization time and money (Strong \& Harder, 2009). Chandler (2004) estimated it could cost Extension from $\$ 7,185$ to $\$ 30,000$ to replace an agent who had an annual salary of $\$ 30,000$ (p. 2). At the local level, where public loyalty is built on relationships, there is also a loss of human and social capital (Brodeur, Higgins, GalindoGonzalez, Craig, \& Haile, 2011). By retaining employees there is an economic savings to the land-grant system. Strong long-term relationships can be built to provide satisfied clientele with the ability to sway opinions of funding bodies that affect the existence of the Extension Service and the university (Brodeur et al., 2011).

Given the unique position descriptions and work assignments for county-based Extension faculty, there is a greater risk for job dissatisfaction. Ensle (2005) suggests the Extension system needs to support efforts to reduce stress and burnout. Administrators can assist in cultivating job satisfaction through both intrinsic and extrinsic rewards for their county Extension faculty. 
Intrinsic rewards are internally generated. Examples of intrinsic rewards for a county Extension faculty include the satisfaction of seeing a job completed, receiving recognition from others, and having an appreciation for the work itself. Extrinsic rewards are generated in the external environment, and include salary and fringe benefits, office space, computer equipment, and type of employee supervision.

\section{Purpose of the Study}

The purpose of the study is to evaluate the work environment and job satisfaction of county Extension faculty members in fifty-five West Virginia counties under the auspices of the West Virginia University Extension Service, utilizing a work motivation construct, generational cohort framework, and faculty rank schema.

\section{Research Questions}

The research questions for this study are:

1. What is the demographic profile (gender, generational cohort based on year of birth, tenure status, academic rank, area of significance [teaching and research or teaching and service], number of program areas served, and years of service) as a county Extension faculty member in West Virginia?

2. What is the work environment profile of county Extension faculty in West Virginia (average number of hours worked a week, number of overnights away from home per year, number of direct contacts, number of people supervised, and percent of time spent per year on teaching/research/service)?

3. What is the overall job satisfaction among county based Extension faculty?

4. Are county Extension faculty more intrinsically motivated or extrinsically motivated? 
5. Is there a correlation between the overall level of job satisfaction of county Extension faculty, and intrinsic and extrinsic work factors?

6. Are there differences between generational cohorts and faculty tenure and non-tenure status on general job satisfaction, intrinsic job satisfaction, and extrinsic job satisfaction among county Extension faculty?

\section{Significance of the Study}

While studies have focused on job satisfaction and faculty working in the Extension System, none have focused specifically on evaluating factors related to job satisfaction and generational cohorts. The results of this study will create a better understanding of how Extension faculty are professionally motivated in their work. The study findings will assist the West Virginia University Extension Service system by providing empirical data that will indicate the job satisfaction level, and extrinsic and intrinsic work factors of county Extension faculty. Faculty professional development opportunities and mentoring programs could be designed and implemented according to perceptions of county faculty. This would be in contrast to relying on views or opinions of administrators, state specialists, and human resources. In order to enhance the effectiveness of Extension employees, it would be beneficial to provide county-based Extension faculty the opportunity to assess motivational factors. In addition, results could assist the organization in learning how to best serve its' employees by designing experiences that lead to improved employee satisfaction and an opportunity to reduce turnover.

The study will assess job satisfaction for each generational cohort. If it is determined that job satisfaction varies with age, results will enable administrators to have a better understanding of their faculty work environment and how to best meet their needs through mentoring, 
professional development, and training. It may also assist senior faculty as they strive to mentor new professionals.

It is important a baseline of the job satisfaction and motivational factors of county Extension faculty be established. This information will assist the Extension System in supporting faculty, resulting in an enhanced work output and increasing the value of the Extension System's capability to better serve clientele. In addition, job satisfaction levels and motivational factors of novice and experienced county Extension faculty will be determined to better support individuals from each generation.

\section{Definitions of Terms}

The following definitions of terms will assist in understanding the research study:

- County Extension Faculty: Faculty working in land-grant institutions' county based extension offices and usually designated as "agents" or "educators."

- County Extension Office: An office operated by the land-grant higher education institution at the county level.

- Extension Committee on Organization and Policy (ECOP): The governing committee for the Cooperative Extension System through the Association of Public and Land-grant Universities.

- Extension Committee on Organization and Policy (ECOP) Leadership Advisory Council (LAC): Represents various sectors of the Cooperative Extension System in assisting the Extension Committee on Organization and Policy on setting a framework and agenda.

- Extension Director: The top manager and decision maker for a state Extension Service.

- Extension Service: The organization that carries out the mandate for outreach education of the land-grant higher education institution at the state level. 
- Extension System: The total Extension organization for the United States, including all employees at the state and county levels.

- Generational Cohort: A group of individuals born in the same general timespan who have shared key life experiences at critical developmental stages (Howe \& Strauss, 2000; Kupperschmidt, 2000).

- Land Grant System: The colleges or universities in each state established by the Morrill Land Grant College Act of 1862 to promote liberal and practical education of the industrial classes in such areas as agriculture and mechanical arts.

- Motivation-Hygiene Theory: Job satisfaction theory by Frederick Herzberg states that factors involved in yielding job satisfaction are separate and different from the factors leading to job dissatisfaction (Herzberg, 2003).

- Motivation-Hygiene Theory Hygiene Factors: Hygiene factors extrinsic to the job that produce job dissatisfaction include: supervision, salary, policy and administration, interpersonal relationships, and working conditions (Herzberg, 1966).

- Motivation-Hygiene Theory Motivator Factors: Motivator factors intrinsic to the job that produce job satisfaction include: achievement, recognition, work itself, responsibility, and advancement.

- State Specialists: Extension faculty educators responsible for the development and implementation of statewide programming efforts.

\section{Summary}

This chapter outlined the background of the problem for the purpose of the study. Chapter two will provide a literature review and chapter three will outline the methodology of 
the study. Chapter four will describe the findings and chapter five will include summary, conclusions, and recommendations sections. 


\section{Chapter 2}

\section{Review of Literature}

\section{The Extension Service}

History of the Extension Service. The Extension Service is often referred to as the outreach branch of the land-grant system of teaching, research, and outreach. In 1862, President Abraham Lincoln signed into law the Morrill Act of 1862 providing each state with public lands to create land-grant higher education institutions specializing in practical professions such as agriculture, home economics, mechanics, and military tactics. The purpose of the land-grant system was to make higher education more accessible. The Hatch Act of 1887 was then passed to provide funding for each state to conduct agricultural research at land-grant institutions through an agricultural experiment station. In 1890, the second Morrill Land-Grant Act led to the creation of many of America's historically black colleges and universities. Finally in 1914, the Smith-Lever Act formalized the Extension Service, which was created from a need for practical application of research and education.

According to Bliss, Symons, Wilson, Gallup, Reese and Schruben (1952), the Extension Service came about from two unrelated movements, one in the USDA and one in the land-grant institutions, which were merged through the Smith-Lever Act establishing a partnership to provide for cooperative agricultural Extension work. The mission of the Smith-Lever Act of 1914 was to:

aid in diffusing among the people of the United States useful and practical information on subjects relating to agriculture, uses of solar energy with respect to agriculture, home economics, and rural energy, and to encourage the application of the same. (Smith-Lever Act, 1914). 
The Smith-Lever Act (1914) established the formal partnerships between local, state, and federal governments to establish educational outreach within local communities.

The Extension Service of today. Today Extension programs are administered through the nation's more than a hundred land grant institutions working together alongside residents to address local problems or concerns utilizing the research from the land grant institution through non-formal, non-credit programs (USDA, 2011). The United States Department of Agriculture (USDA) National Institute of Food and Agriculture (NIFA) serves as the federal partner of the local, state, and federal partnership implementing Extension programs. According to the USDA (2011), NIFA distributes “....annual Congressionally appropriated formula grants to supplement state and county funds. NIFA affects how these formula grants are used through national program leadership to help identify timely national priorities and ways to address them" (Paragraph 2). Varner (2011) states:

Many would agree that as the world's largest non-formal adult education organization, Cooperative Extension has an impressive track record when one considers that it is not a mandated system, but rather an organization that survives and thrives based upon its ability to enhance peoples' lives by helping individuals, families, and businesses and communities put research-based knowledge to work. (p. 15)

In 2001, according to McDowell (2001), there were approximately 15,000 full time equivalent staff employed by the Cooperative Extension across the country. There were also Extension offices located in about 70 percent of the nations' 3,066 counties. Counties where there was not an office were being served by staff in adjacent offices or through regional offices. McDowell (2011) states that Extension staff are protected by university tenure and the institutional setting. This allows Extension field staff to influence research and serve as 
educators. Extension faculty can identify and describe problems as a result of their experiences working in the field. They also voice their knowledge with freedom about the issues that affect their clientele, even if it is an unpopular message for those that they serve.

Today another significant component of the Extension system to disperse knowledge through the land-grant system is eXtension. An online interactive learning website, eXtension provides researched based knowledge from across the United States. The website provides an opportunity for educators, students, clinicians, and the public to connect in providing and gathering educational and information resources on a variety of topics (eXtension, 2013). Examples of eXtension resource areas, known as Communities of Practice, include disaster issues, energy, environment, family, farm, health and nutrition, pest management, and youth. Professional educators with expertise in the subject area join together from across institutions to oversee the Communities of Practice.

Land-grant institutions in West Virginia. There are two higher education institutions in West Virginia with land-grant status. West Virginia University and West Virginia State University.

West Virginia University (WVU), established in 1867, was founded from the Morrill Act of 1862. The mission of WVU (2011) as a land-grant institution is to "deliver high-quality education, excel in discovery and innovation, model a culture of diversity and inclusion, promote health and vitality, and build pathways for the exchange of knowledge and opportunity between the state, the nation, and the world" (Paragraph 1). At WVU the West Virginia University Extension Service (WVUES) is its' own unit, separate from the Davis College of Agriculture, Natural Resources, and Design. This is different from some of the other Extension Service landgrant systems, where the Extension Service is under the institution's school of agriculture. At 
WVU the Extension Service is the third largest academic unit after the School of Medicine and the Eberly College of Arts and Sciences (S. Bonanno, personal communication, March 14, 2013). The WVUES has an office in each of West Virginia's 55 counties.

West Virginia State University (WVSU), established in 1891, was founded as a historically black land-grant institution from the Morrill Act of 1890. However, WVSU has not always maintained its land-grant status. In 1956, according to WVSU (2013) the West Virginia State Board of Education voted to surrender the land-grant status of WVSU effective July of 1957 and transfer all personnel and expense funds to West Virginia University. In 1991, the state legislature voted to re-designate WVSU as an 1890 Land-Grant Institution. In 2001, landgrant status was reinstated to WVSU and the institution again became a fully recognized 1890 Land-Grant Institution (WVSU, 2013). Today at WVSU, the Gus R. Douglass Land-Grant Institute is comprised of three programmatic divisions: West Virginia State University Extension Service; West Virginia State University Agricultural and Environmental Research Station; and The Center for the Advancement of Science, Technology, Engineering and Mathematics (WVSU, 2013).

Role of county Extension faculty member. Seaman A. Knapp, founding father of the work of the Extension service who began his work in 1904, outlined his vision to Extension workers (Bliss, Symons, Wilson, Gallup, Reese, \& Schruben, 1954):

Your mission is to solve the problems of poverty, to increase the measure of happiness, to add to universal love of country the universal knowledge of comfort, to harness the forces of all learning, and to be useful and needful in human society. (p. 219)

The role of a county Extension faculty member is one that is unique and multi-faceted. County Extension faculty live in the communities in which they work and are immersed in 
addressing the problems faced by communities through educational programming. By operating the county Extension office, faculty serve as the presence in the local communities for the landgrant institution fulfilling the mission of outreach. County Extension faculty serve as both teachers and facilitators, serving as an expert source of information and bringing together existing community resources to address concerns through capacity building (Raison, 2010).

County Extension Faculty Members at West Virginia University. As illustrated in Figure 1, the West Virginia University (WVU) Extension Service (2012) provides programs through four programs units: 4-H Youth Development, Families and Health, Agriculture and Natural Resources, and Community, Economic, and Workforce Development.

\section{Figure 1}

West Virginia University Extension Service Program Organizational Chart

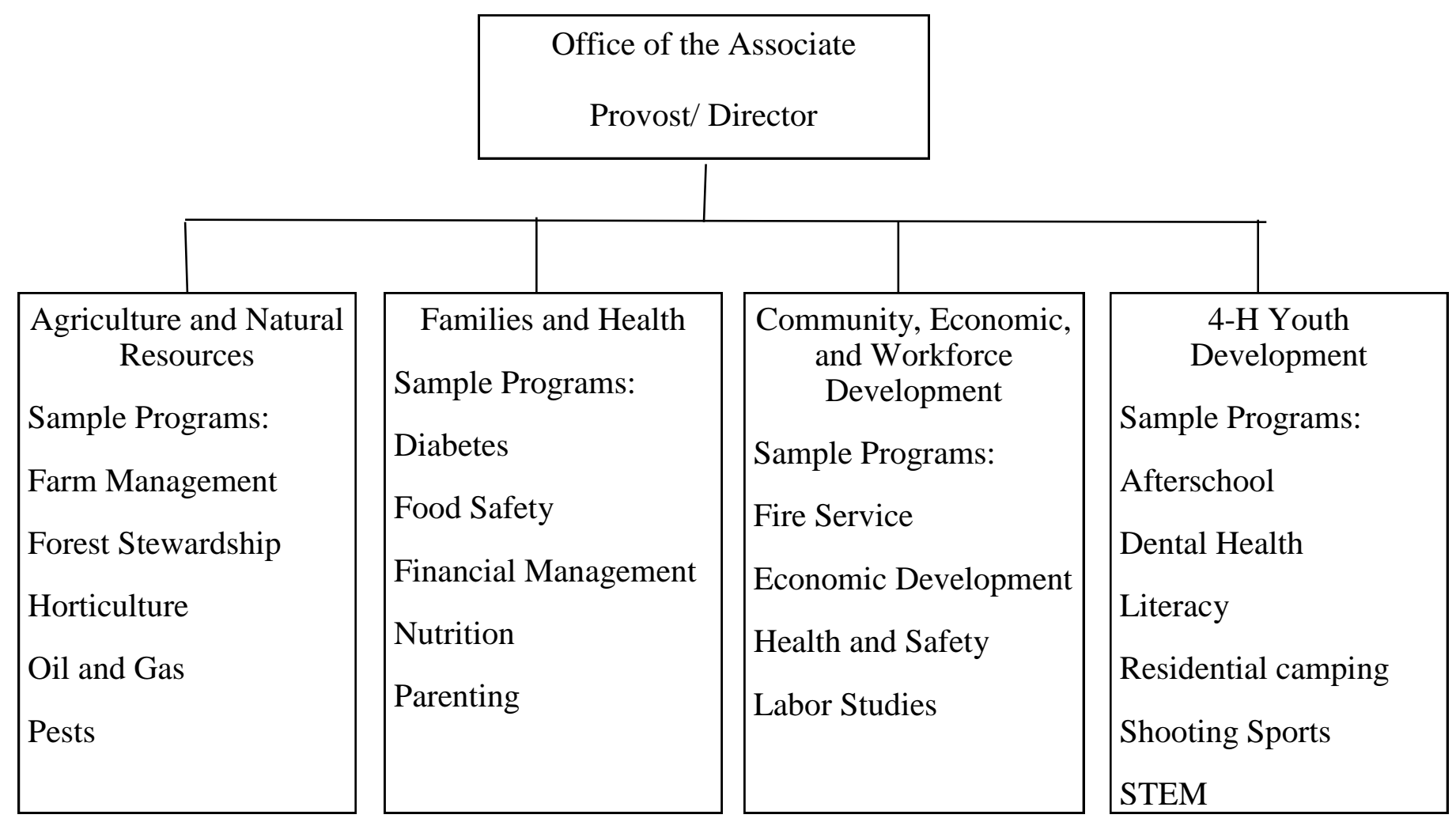


Although county Extension faculty have a primary assignment to one unit, they complete work in many or all of the programming areas. Local governments including county commissions and boards of education help fund WVU Extension Service efforts; this includes partial support helping to pay a portion of some Extension agents' and support staff salaries, and often providing office space, utilities, and travel budgets. In each West Virginia county an Extension Service Committee gives "guidance and assistance in the development of the county cooperative extension service program and in the preparation of the annual plan of work for the county" (West Virginia Legislature, 2012, Paragraph 2). The Extension Service Committee: is composed of (a) the president of the county farm bureau, (b) the president of the county extension homemakers council, (c) the president of the county Four-H leaders' association, (d) a county commissioner designated by the president of the county commission, (e) a member of the county board of education designated by the president of the county board of education, (f) a county representative of the grange, and (g) two members who are residents of the county to be appointed by the board of advisors of West Virginia University. (Agriculture, 2012, Paragraph 1)

A grange is an association of farmers in the United States who helped to establish the 4-H organization. According to Z. Hutson (personal communication, March 10, 2013) there are few active granges left in West Virginia. The Extension Service Committee serves as a local governing board and members vote on Extension faculty member's annual reappointment to the county.

Due to the demands of the profession, county based Extension faculty with West Virginia University work varied schedules, including many evenings and weekends resulting in job flexibility. They have the opportunity to design their own plan of work and professional 
development plans, as long as they are addressing the primary educational needs of their constituents and meeting the minimal requirements of the institution. Their work is self-directed, and with supervisors based out of Morgantown, they have limited direct supervision. County Extension faculty are in the promotion and tenure system with teaching, research, and service requirements. Beginning in 1985 WVUES educators were granted faculty status in Extension, and most faculty were assigned research and teaching as their significant areas of contribution. However, in 2003, several county Extension faculty changed their area of significant contribution from research and teaching to service and teaching, and are now required to document scholarship in the area of service (Nichols, 2004).

West Virginia University Extension Service county Extension faculty experience diversity in their job, with every day and every season bringing new opportunities and work experiences. Many programming efforts occur at the same time each year; for example, Extension faculty working in agriculture spend much of spring addressing gardening questions; 4-H youth development faculty spend time each summer conducting residential camping programs; and family consumer science faculty spend much of their time late summer and early fall addressing canning and preserving questions. Since county Extension faculty serve in the communities in which they live, they have the opportunity to see the impact they are making on people's lives through their programming efforts. They involve colleagues and community members in their work efforts through all programming stages from program development to evaluation (LaMuth, 2005).

\section{Generational Cohorts in the Workforce}

Mannheim (1952) is credited with the application of the generational theory. Roberts and Lang (1985) explain that the generational theory proposes that people who are born during a 
particular time in history often share similar experiences which contribute to the formation of their level of social awareness and consciousness. Today a generational cohort has been redefined as individuals born in the same general time span who have shared key life experiences at critical developmental stages (Howe \& Strauss, 2000; Kupperschmidt, 2000). Examples may include historical events, public heroes, entertainment pastimes, and parenting and school system values. Weston (2001) explains that a cohort's common life experiences create cohesiveness in perspectives and attitudes and define the unspoken assumptions of the generation. Cennamo and Gardner (2008) observed that generational differences are multiplied by changes due to aging, experiences, life stage and career stage. Therefore, employees of different age groups do not share the same work ethic or expectations in relation to important workplace components such as supervision, recognition, and time off. As illustrated in Table 1, the workforce today is composed of three distinct generational cohorts. The three generational cohorts currently in the workforce include the Baby Boomers, Generation X, and Millennials.

\section{Table 1}

\section{Descriptions of Generations Currently in the Workforce}

\begin{tabular}{|c|c|c|c|c|}
\hline Generation & $\begin{array}{l}\text { Respect for } \\
\text { Authority }\end{array}$ & $\begin{array}{l}\text { Interactions } \\
\text { with Others }\end{array}$ & Time Management & $\begin{array}{l}\text { Rewards, } \\
\text { Incentives }\end{array}$ \\
\hline Boomers & $\begin{array}{l}\text { Champions of } \\
\text { democracy }\end{array}$ & $\begin{array}{l}\text { Non-conformists } \\
\text { Self-confident }\end{array}$ & Workaholics & $\begin{array}{l}\text { Money and } \\
\text { attention }\end{array}$ \\
\hline Generation X & $\begin{array}{l}\text { Skeptical } \\
\text { Cynical }\end{array}$ & $\begin{array}{l}\text { Independent } \\
\text { Self-reliant }\end{array}$ & $\begin{array}{l}\text { Work/personal life } \\
\text { balance }\end{array}$ & Time off \\
\hline Millennials & $\begin{array}{l}\text { Test but search } \\
\text { them out. } \\
\text { Want guidance. }\end{array}$ & $\begin{array}{l}\text { Optimistic } \\
\text { Team players }\end{array}$ & $\begin{array}{l}\text { Ambitious } \\
\text { Over-extended }\end{array}$ & $\begin{array}{l}\text { Immediate } \\
\text { feedback. } \\
\text { Everyone is } \\
\text { rewarded. }\end{array}$ \\
\hline
\end{tabular}

Note: Adapted from Howe and Strauss 2000; Marston, 2007. 
The United States is in the beginning stages of the mass exit of Baby Boomers from the workforce, a generation born between 1946 and 1964 (Marston, 2007). Baby Boomers, the largest generation in history, who coined the term 'workaholics' have been delaying entry into retirement. They are a sandwiched generation, facing responsibility of providing support and caregiving for elderly loved ones and often adult children who may still living at home and perhaps even grandchildren. According to Cordeniz (2002), Baby Boomers are driven and dedicated workers who associate work with self-worth, contribution, and personal fulfillment. Baby Boomers entered adolescence during a period of unrest and a desire to make a difference, experiencing civil rights protests, antiwar protests, and the fight for gender equality. Through these experiences, many Baby Boomers selected their profession based not on economic prospects, but with the desire to make the world a better place. Cennamo and Gardner (2008) found that Baby Boomers reported better "person-organization values" than Generation X and Millennials.

The younger generations, Generation X and the Millennials, do not follow traditional styles and patterns of work behavior. Generation X, a generation born between 1965 and 1979, grew up as latchkey children and learned early how to be self-reliant because both parents were working (Marston, 2007). Generation X values hard work, and associates working hard with one's worth more so than Baby Boomers (Smola \& Sutton, 2002). Although members of Generation $\mathrm{X}$ are hard workers, they strive for a balance between work and personal life rejecting the workaholic character of their parents. Generation $\mathrm{X}$ thinks of "hard work as effective output, and they are unwilling to put in long hours if they have produced the output necessary for that day" (Marston, 2007, p. 58). Twenge (2010) found Generation X'ers were significantly more likely to value the extrinsic work factors of salary, status, and prestige than 
Baby Boomers. While the value placed on these extrinsic factors was decreased between Generation X and GenMe (Millennials), they were still significantly higher among GenMe (Millennials) than Baby Boomers.

In contrast, the Millennial generation, born between 1980 and 2000, are reshaping the job market (Marston, 2007). According to Lyons (2004) the most defining experience for this generation is the growth of the Internet and technology. Millennials are defined as a generation that feels entitled and has expectation of quick prospects for opportunities, titles, and promotions. Research done by Twenge and Campbell (2008) has shown Millennials have higher levels of self-esteem and narcissism compared to past generations. In addition Millennials expect to be motivated by the vision and management of the company, and they also expect to have the opportunity to make contributions as an employees. Unlike Boomers who would stay in one job for a lifetime, Millennials do not hesitate to move around the job market searching for the next best opportunity. They can also be outspoken and can be perceived as disrespectful of supervisors and other authority figures or coworkers in their work environment (Crow and Stichnote, 2010; Marston, 2007).

The United States Bureau of Labor Statistics (2010) reports the average younger employee, ages $25-34$, leaves his or her job every 3.1 years. This is in contrast to middle-age employees, ages 45-54 who leave every 7.8 years, and older employees, 55-64, who leave every 10 years. According to Marston (2007), if an employee is retained for four years, turnover numbers drop dramatically. He contends this is due to an adjustment to the workplace, and to connections with workplace mentors or coaches.

There has been some questions raised regarding the legitimacy of generations to the work environment. According to Parry and Urwin (2010) some studies have been unable to find 
predicted differences in work values based on generation. They cite a lack of consideration for nationality, gender, ethnicity, and generation as opposed to cohort. They recommend further research to distinguish generational effects from age. Rhodes (1983) suggests that longitudinal data is needed to understand whether differences in job satisfaction is due to either age or generational cohort effects, or environmental differences. Wong, Gardiner, Lang, and Couon (2008) also studied the differences between generations in the workplace, and determined that differences were better explained by career stages rather than generational differences.

\section{Herzberg Motivation-Hygiene Theory}

Herzberg's (1966) Motivation-Hygiene Theory is a two-factor theory of 10 work factors. He identified five motivator factors, or intrinsic factors, that contribute to internal growth and motivate the employee to superior performance and effort (Herzberg, 1966). These factors are related to the employee's relationship to the job itself. These include: achievement, the work itself, responsibility, recognition, and advancement. The motivator factors contribute to one's job satisfaction, creating lasting changes of attitude (Herzberg, 1966).

Five hygiene, or extrinsic factors, are derived from the actual work environment, describing the relationship to the context or environment. The hygiene factors have little effect on positive job attitudes, and can create job dissatisfaction (Herzberg, 1966). These factors include: supervision, salary, policy and administration, interpersonal relationships, and working conditions.

According to Herzberg (2003) the appropriate amounts of motivators can bring about work motivation that leads to job satisfaction; however the hygiene factors serve primarily to prevent job dissatisfaction. Overall, the basis of the theory is that motivator factors lead to "job satisfaction due to a need for professional growth or self-actualization" (Herzberg, 1966, p. 75). 
In contrast, hygiene factors can lead to "job dissatisfaction due to a need to avoid unpleasantness" (Herzberg, 1966, p. 75).

\section{Motivator (Intrinsic) Factors}

Achievement is the first motivator factor. According to Herzberg (1966) achievement is the successful completion of a job, solving problems, and seeing the results of one's work. This intrinsic factor can also include the opposite of achievement, including failure or lack of achievement. For faculty in higher education achievement is the measure of professional productivity, including publications and presentations (August \& Waltman, 2004). The ASHE Higher Education Report (2008) states there is a variety of methods of achievement for faculty from community engagement to traditional publication.

Extension Service programs are primarily created and implemented to bring about desirable changes in clientele and communities (Utz Jr., 1965). Extension faculty have the opportunity to see the impact of their work through participant evaluations measuring behavior and attitudinal changes, long term interaction with clientele, and working alongside fellow citizens to address community concerns (Fox \& Cater, 2011).

The second intrinsic factor according to Herzberg (1966) was the work itself, described as the actual doing and tasks of the job. The role of tenure track faculty members in higher education generally encompasses teaching, research, and service responsibilities. Professors must also engage in field work, serve on graduate committees, write grants to support research and conduct research when not teaching. (June \& Mangan, 2011). In addition to the academic year, faculty often work in the summer uncompensated, except for summer school teaching and grant-funded activities. 
The work of county based Extension faculty is complex and extensive. The primary role of Extension is to disseminate the research-based knowledge of the land-grant institution to the people it serves. This occurs through a variety of techniques including developing programs, facilitating meetings, non-formal teaching, technical expertise, and serving as organizers through developing leadership and building relationships (Peters, 2002). Extension faculty provide education and information locally to address the needs of individuals, families, businesses, and communities (Place \& Jacob, 2001). Amend (1970) defines county Extension faculty as “practical sociologists” (p. 19).

Responsibility, the third intrinsic factor, includes all "factors relating to responsibility and authority" including “derived satisfaction from being given responsibility” for one's own work or the work of others, or from being given new responsibilities at work (Herzberg, 1966, p. 196). The primary responsibility for higher education faculty is to facilitate student success. Work for faculty is intellectually demanding, requiring autonomy and freedom to pursue their work. The necessity of such autonomy means universities rely on the intrinsic motivation of faculty and their commitment to the discipline, university, and students (Marlin, 2012).

Through the responsibility given to Extension faculty, they are able to bring about significant positive impact among individuals and communities, while addressing a variety of issues, needs, and problems (Place \& Jacob, 2001). Extension faculty have a great amount of responsibility. A significant amount of this responsibility includes educating oneself on different topics through professional development to address critical needs. The faculty member must be self-motivated and also know how to motivate one's clientele (Amend, 1970). Clegg (1967) states that Extension faculty have "responsible freedom on the job" (p. 24). 
Recognition, the fourth intrinsic factor, is receiving acknowledgment from others. This includes recognition that is either positive or negative (Herzberg, 1966). This recognition can be received from a supervisor, peer, client, or general public. In higher education the faculty reward system is publication in books and in peer reviewed journals, and presentations at professional conferences. Teaching awards are commonly regarded as an incentive to encourage pedagogic excellence for higher education faculty (Brawer, Steinert, St-Cyr, Watters, \& Dauphinee, 2006). Boyer (1990) recommended the faculty reward systems match the full range of academic functions, and the multiple forms of scholarship should align the faculty reward system with the mission of the institution. According to O'Meara (2006), restructuring faculty reward systems to promote a multitude of forms of scholarship will positively influence acceptance of the work within academic cultures.

Like traditional faculty members, county-based Extension faculty also receive recognition through acceptance in peer reviewed scholarly journals and being selected to make presentations at professional conferences. According to Strong and Harder (2009) the lack of a reward system within an organization can result in unintended consequences. Rouson and Henderson (1996) found Extension faculty have left the organization due to a lack of recognition for work well done.

The fifth intrinsic factor identified by Herzberg (1966) was advancement. Advancement was defined as a change in employee's status or position. Tenure track faculty gain advancement through the promotion and tenure system. A promotion and tenure evaluation is comprised of three components: teaching, research, and service. The evaluation of both teaching and research are critical components in promotion and tenure decisions (Luchs, Seymoure, \&Smith, 2012). Young and Price (2009) state that a faculty member ordinarily receives tenure and promotion 
sometime during his or her mid- or late-thirties. To be reappointed and/or promoted, faculty must submit a dossier describing their work and accomplishments during their previous contract periods, along with evidence of those accomplishments (Beyer, 2011). This includes documenting significance through their teaching, research, and service accomplishments.

Scholarly achievement and excellence in completing assigned responsibilities is the primary criteria for evaluating faculty performance (Weiser \& Houglum, 1998). A survey conducted by Olsen (2005) determined county Extension educators are classified as faculty or parallel to faculty at $58 \%$ of the land-grant universities. Parallel to faculty is defined as when promotion is done (or denied) inside of Extension instead of through a university wide process. County educators were eligible for tenure or equivalent, continuing appointment or extended term, at $50 \%$ of the land-grant universities (Olsen, 2005).

\section{Hygiene (Extrinsic) Factors}

The first extrinsic factor is supervision, which includes a variety of components including fairness, delegation of responsibility, and effectiveness (Herzberg, 1966). Supervision includes all interactions with one's supervisor, whether the interactions are positive or negative.

Supervision of higher education faculty occurs through promotion and tenure review, where the supervisor and peers assess the rigor, quality, and impact of the faculty members' teaching, research, and service activities. Supervisors also manage the course workload, class schedules, committee work, and may assist with a research or outreach agenda. Del Favero (2003) acknowledges a lack of knowledge around the relationship between faculty and administrators in colleges and universities, including their partnership through shared governance.

Unlike traditional higher education faculty, county-based Extension faculty are often located many miles away from their institution and their immediate supervisor, resulting in 
limited direct supervision (Amend, 1970). The supervisor operates remotely, and must be cognizant and responsible to faculty and their various program responsibilities. A significant role of the supervisor is to help the faculty member understand the role of Extension and how the faculty member effectively works to promote the organization's mission (Amend, 1970). This also includes evaluating if the faculty member is overly motivated, which can result in physical and emotional exhaustion due to a heavy workload (Clegg, 1967).

The second extrinsic factor, salary, is all sequences involving wage or salary increases, and all events in which compensation plays a part (Herzberg, 1966). Typically in higher education, according to Melguizo and Strober (2007), faculty pay is measured by years since their doctorate was received and their research output. Fulltime faculty receive merit salary increases as a reward for exceptional performance in teaching, research, and service. Merit is contingent on meeting all expectations and having exceptional performance in at least one area (Beyer, 2011). In addition, annual raises at public higher education institutions are affected by state legislative budgets and tuition increases. According to Knapp, Kelly-Reid, and Ginder, (2011) the adjusted nine month average salary for faculty in four-year public institutions in the $2010-2011$ academic year in the United States was $\$ 77,706$. This is compared to $\$ 77,344$ for 2008-2009 academic year (Knapp, Kelly-Reid, \& Ginder, 2009).

It has been cited that Extension faculty leave the profession due to the amount of salary received compared to the amount of work or the lack of a competitive salary (Rousan and Henderson, 1996). County based Extension faculty have twelve month contracts. The starting salary of a county based Extension faculty member at WVUES at the level of Extension Instructor is $\$ 40,000$ to $\$ 43,000$. The average salary of WVUES county based Extension faculty 
for 2012 was $\$ 52,310$, compared to $\$ 49,428$ in 2008 (J. Momen, personal communication, March 25, 2013). The 2012 amount is equivalent to a nine month salary of $\$ 42,799$.

Policy and administration, the third extrinsic factor, is defined by Herzberg (1966) as the organization and management characteristics in the workplace, including workplace policies. Shared governance has a significant role in higher education. According to Langland (2011), public higher education institutions continue to experience a loss of state revenues moving from state supported to "state related." Shared governance in times of revenue reduction requires more faculty deliberation and consultation, with everyone invested in the success of the institution. This shared governance by faculty instills a sense of responsibility for faculty to keep academics at the heart of the institution (Crellin, 2010).

Policy and administration in the Extension Service primarily takes place through the federal, state, and local partnership structure of the organization. County-based faculty members must follow policies established by the land-grant institutions, while also striving to meet the desires of local funding bodies and clientele. Unclear policies and politics were cited as reasons for turnover in county positions in a research study completed by Rousan and Henderson (1996) with the Ohio State University Extension Service.

The fourth extrinsic factor is interpersonal relationships. Herzberg (1966) admits interpersonal relationships could include almost all interaction of employee and other individuals. However, through his research, interpersonal relationships were identified when his research participants verbalized the "characteristics of the interaction between the person speaking and another individual" (p. 195). This included three major categories: interpersonal relations with a superior, interpersonal relations with subordinates, and interpersonal relations with peers. Higher education faculty experience a variety of professional interpersonal 
relationships, with the majority being between administrators, fellow colleagues, staff and students. These interpersonal relationships play a significant role in academic settings. Research conducted by Rugutt and Chemosit (2009) found student-faculty interaction were statistically significant predictors of student motivation. Research conducted by Lechuga (2011) found one of the most important factors graduate students use to ascertain the quality of their educational experience is their relationship with faculty. Faculty-graduate student relationships can be described by three broad descriptors that characterize faculty members as allies, ambassadors, and master-teachers. Interpersonal relationships with peers occur in a variety of formats. Peer relationships occur through promotion and tenure review, partnering on research efforts, securing grants, and team supervision. Team supervision has become a standard practice in higher education and viewed as an effective pedagogy. Team supervision assists with self-regulation and peer-regulation, and assists in mentoring for junior faculty from more experienced faculty (Manathunga, 2012). Interpersonal relations with supervisors take place through scheduled departmental meetings, feedback through promotion and tenure, and individual one-on-one meetings as deemed necessary.

Due to the unique composition of the Extension Service through the state, federal, and local partnership, a county based Extension faculty member is immersed in a variety of interpersonal relationship experiences. This includes a relationship with one's supervisor who is often located many miles away from the faculty member. Interpersonal relationships with peers occur through county faculty working with fellow county faculty and state specialist faculty for program content support, team research projects, and providing joint programming efforts (Amend, 1970). Interpersonal relationships also occur with a variety of clientele including: the local Extension board, known as the Extension Service Committee in West Virginia; all boards 
and committees the faculty member serves on, interacts with, and oversees; volunteers; and all other youth and adults who participate in Extension programs. These relationships play out in a unique manner when the Extension faculty members lives in the communities in which they work, creating interactions not only in a work setting but also through personal interactions such as at church or the grocery store. As a result of their public role within the community, county based Extension faculty members are always on duty even during off hours.

The last extrinsic factor is working conditions; the physical conditions of work including facilities, amount of work, and work flexibility or inflexibility related to time and space.

According to June (2012) faculty in the tenure system have shrunk, which is $30 \%$ of the nation's professoriate, have decreased steadily over the past 25 years. At the same time, the amount of faculty service and committee service has increased exponentially.

A career in Extension includes job stress with faculty working long and irregular hours, including working many nights and weekends (Place \& Jacob, 2001; Rousan \& Henderson, 1996; Strong \& Harder, 2009). County-based Extension faculty must be able to multi-task, often working on many projects simultaneously (Hinkle, Sparks, Mason, \& Vail, 2003). Teaching through the Extension Service does not take place in a typical classroom. Extension faculty have been teaching through experiential learning for decades (Enfield, Schmitt-McQuitty, \& Smith, 2007; Torock, 2009). Experiential learning involves the active involvement of learners actually doing or performing the activity, reflection where learners react and process the experience, and application which helps learners broaden their understanding of the concept by generalizing their experience (Enfield, et al., 2007). According to Torock (2009) this requires learners to recall prior knowledge, introduce new knowledge, and helps them make the connection between the two for individual internalization. Therefore hands-on teaching efforts of county Extension 
faculty take place in the field, not in a typical classroom setting like teaching completed by traditional faculty members. Kroth and Peutz (2011) completed research on future workplace issues in Extension with Extension faculty at the 2006/2007 and 2007/2008 Western Extension Leadership Development program and the 2007 and 2008 National Extension Leadership Development program. A three-round Delphi study was completed, with 46 participants in the first round, 35 in the second round, and 30 in the third round. Two of the top nine issues related to components of working conditions including having a healthy interpersonal work climate, including diversity, collaboration, and multidisciplinary efforts (round 2 response $M=5.24$ and round 3 response $M=4.93$ ) and keeping up-to-date with technology (round 2 response $M=4.68$ and round 3 response $M=4.63$ ).

\section{Traditional faculty}

According to the National Center for Education Statistics (2012) the majority of traditional faculty in degree-granting institutions were male (51.8\%), while 48.2 percent were female. According to a national survey of college and universities conducted through the Higher Education Research Institute (HERI) in 2010 to 2011, the largest group of undergraduate higher education faculty were Baby Boomers, born between 1945 and 1965 (60.6\%) (Hurtado, Eagan, Pryor, Whang, and Tran, 2012). A little more than a third were Generation X'ers (35.6\%), born between 1966 and 1980. Only 2.6 percent are Millennials, born in 1981 or later. Finally, a small group of faculty (1.5\%) was born in 1940 or earlier.

The HERI study found 56.2 percent of full-time undergraduate faculty were tenured (Hurtado et al., 2012). That study also found that 31.9 percent of full-time undergraduate faculty at public universities were at the rank of professor, the next largest rank was assistant professor at 24.9 percent with associate professor following closely behind at 24.5 percent. 
In research universities, traditional faculty generally have research and teaching as their significant areas of contribution. Of faculty at public universities, 80.6 percent spend up to 16 hours a week on classroom and preparatory teaching activities, 78.8 percent spend up to 16 hours on research activities, and an average of 70.9 percent spend up to 8 hours on service activities such as advising, committee assignments, and public service.

Full-time undergraduate faculty at public universities completing the HERI study reported an average of 5 to 8 hours teaching per week (40.6\%), an average of 5 to 8 hours preparing for teaching per week $(25.1 \%)$, one to four hours per week on research and scholarly writing (25.4\%), and 49.9 percent of reported completing no community or public service on average per week (Hurtado et al., 2012). In addition, traditional faculty have numerous commitments including counseling and advising students, committee work and meetings, and other administrative duties. While faculty in the tenure system have shrunk, faculty service and committee service have increased (June, 2012). According to the Chronicle of Higher Education (2011), the average nine month salary of agriculture, agriculture operations, and related sciences faculty at four year colleges and universities for 2010 to 2011 was $\$ 45,057$.

\section{Job Satisfaction in the Extension Service}

A review of the literature reveals job satisfaction has been researched to some extent in various Extension Service systems. A follow-up study to demonstrate the reliability of Herzberg's Motivation-Hygiene Theory was completed by Dr. Denzil Clegg in 1961 with County Agriculture Extension workers $(n=58)$, or county based Extension faculty, at the University of Nebraska. The primary reason for the research was to ascertain if the motivationhygiene theory of job attitudes could be applied to personnel who were spread out over an entire state, instead of working in a central location (Herzberg, 1966). Clegg completed a minor 
variation of the research methods, adding two factors unique to the Extension service. This included adding two hygiene factors, "interpersonal relations with clientele and relationships with members of the Extension board" (p. 105). Research results showed two motivators predicted satisfaction: achievement and recognition. In contract, six hygiene factors were significantly related to dissatisfaction, including company policy and administration, working conditions, interpersonal relations with subordinates and with peers, supervision, personal life, and relationships with the extension board (Herzberg, 1966).

More recent studies on job satisfaction have also been completed in different regions of the country with county based Extension faculty. According to Riggs and Beus (1993), a random sample of Extension County Agents $(n=214)$ working in the Western region including Arizona, Colorado, Idaho, Montana, Nevada, New Mexico, Utah and Wyoming were surveyed on coping strategies and effective ways of reducing job stress. Results indicated the county agents were moderately satisfied with their jobs. Results also showed that as the number of agent responsibilities increased, job satisfaction decreased. Agents who had little or no child rearing responsibilities at home were more satisfied. In addition, agents who were able to use reframing were able to cope better with stressful situations. Hepworth and Larsen (1993) describe reframing as countering feelings of powerlessness by recognizing change is possible, which can result in an improved situation. This includes redefining the difficulty in a new perspective and designing actions that can be successfully taken to resolve the problem.

According to Kutilek (2000), a study at Ohio State University Extension system of 67 county agents who voluntarily vacated their positions cited job stress, low pay, and a lack of supervisory support were the reasons for why they left. 
Nestor and Leary (2000) studied the job satisfaction between tenure and non-tenure track status of Extension faculty at the West Virginia University Extension Service utilizing Herzberg's job satisfaction/job dissatisfaction theory. The study found that non-tenure track status faculty had a statistically significant relationship with their intrinsic job satisfaction. However, there was not a significant relationship between non-tenure track status faculty and their extrinsic satisfaction or overall job satisfaction. Nor was there any statistically significant relationship for tenure track faculty for intrinsic satisfaction, extrinsic satisfaction, or overall job satisfaction.

Stark (2011) researched the relationship among workload, job satisfaction and burnout of Extension 4-H youth development professionals $(n=241)$ from six land-grant universities in the northwest, including Idaho, Washington, Montana, Colorado, Wyoming, and Oregon. 4-H youth professionals were assessed on how they chose to spend their work time and how workload related to job satisfaction and burnout by ranking seven pre-determined job responsibilities, based on the 4-H Professional, Research, Knowledge and Competencies (4-H PRKC). The job responsibility that provided the greatest degree of job satisfaction was "develop programs to practice life skills" $(M=1.93$ and $S D=0.72)$. The job responsibility that provided the lowest level of job satisfaction was "dealing with conflict management" $(M=2.81, S D=0.92)$. The Job Satisfaction Survey (JSS) was used with a mean score of $3.72(S D=0.79)$ from a Likert-type scale format with six choices per item, ranging from disagree very much to agree very much. Finally, self-reported overall level of job satisfaction was measured with a mean of $2.20(S D=$ 0.83 ) from a five point Likert-type scale with $1=$ extremely satisfied and $5=$ extremely dissatisfied. 
LaMuth (2006) researched a comparison of formal and non-formal manager educators ( $n$ = 160) within Ohio State University Extension on self-efficacy, training choices, and job satisfaction. Bandura's (1977) theory about the relationships among training, self-efficacy, and job satisfaction provided the theoretical foundation for the study. Job satisfaction was measured using the Global Satisfaction Scale because the researcher wanted to obtain an overall understanding of job satisfaction, including work and the work environment. Findings showed the majority of Extension educators perceived their primary role to be a combination of both teacher and manager regardless of whether or not they had formal management assignments within the organization. The Global Job Satisfaction Scale used a Likert-type scale format with five choices per item. Each scale varied, but were similar with 1 characterizing a negative response to 5 characterizing a positive response. LaMuth (2006) found the items ranked highest and lowest in relation to job satisfaction were closely aligned. Items that received the highest rankings related to job satisfaction were the people with whom they worked, including audiences taught, co-workers, volunteers, and people in community groups and committees. The second most highly ranked item related to job flexibility, freedom, and autonomy related to programming and schedule. The items with the lowest ranking related to job satisfaction included working with difficult people, conflict in the Extension office, and community politics. The second items with low responses related to job satisfaction included the lack of time to do the work expected, long hours, and having to work weekends and evenings.

Hass (2002) researched the communication preferences and job satisfaction levels of North Carolina Cooperative Extension faculty $(n=543)$ utilizing the Communication Preference Questionnaire for identifying language type preferences and a modified version of the Minnesota Satisfaction Questionnaire(MSQ) Short-Form to assess job satisfaction. When compared with 
norm groups faculty were satisfied with their jobs overall. However, Area and 4-H Agents were the lowest satisfied faculty members and the Family and Consumer Science Agents and District Directors had the highest job satisfaction levels. The MSQ had a five point Likert-type scale with $1=$ very satisfied and $5=$ very dissatisfied. Intrinsic job satisfaction had a mean of 50.8 $(S D=4.9)$, extrinsic job satisfaction had a mean of $19.1(S D=5.6)$, and overall job satisfaction was measured with a mean of $77.5(S D=10.3)$.

Some research studies have addressed leadership styles of county and state administrators in relation to employees' job satisfaction. Elizer (2010) researched the relationship between Tennessee County Extension Agents $(n=112)$ job satisfaction utilizing the Mohrman-CookeMohrman Job Satisfaction Scale and their perception of the leadership styles of their Extension directors utilizing the Multifactor Leadership Questionnaire 5x. The Mohrman-Cooke-Mohrman Job Satisfaction Scale was designed to measure intrinsic, extrinsic, and general job satisfaction. The scale consists of eight items with a six-point Likert type scale where responses ranged from $1=$ low and $6=$ high. Intrinsic job satisfaction had a mean of $4.65(S D=1.09)$, extrinsic job satisfaction had a mean of $4.05(S D=1.39)$, and overall job satisfaction was measured with a mean of $4.35(S D=1.24)$. Elizer (2010) found that while the majority of Extension directors were categorized as laissez-fair, the majority of agents indicated high job satisfaction within their profession as Extension agents. It was observed those with high job satisfaction had either worked 11 or more years with the organization; or Extension was their first professional occupation or they had a prior occupation in business, education, Extension in another state, or industry.

Stumpf (2003) researched perceived leadership styles of North Carolina County Extension Directors' to job satisfaction of county Extension field faculty $(n=580)$. Stumpf also 
utilized The Multifactor Leadership Questionnaire 5x and The Mohrman-Cooke-Mohrman Job Satisfaction Scale. Results of the study indicated significant differences in the job satisfaction of Extension professionals based on perceived leadership style of County Extension Directors. Significant findings showed total job satisfaction was positively related to transformational leadership and total job satisfaction was negatively related to transactional leadership. Intrinsic job satisfaction had a mean of $4.54(S D=1.051)$, extrinsic job satisfaction had a mean of 4.351 $(S D=1.066)$, and overall job satisfaction was measured with a mean of $4.444(S D=0.9477)$.

\section{Summary}

Various aspects of job satisfaction at the county level in a variety of Extension Service systems has been researched. Samples of topics assessed in relation to job satisfaction have included tenure status, communications styles, and leadership styles. Research on overall job satisfaction has had varying results from moderately satisfied to very satisfied. Studies have cited Extension faculty working at the county level have experienced job stress, low pay, a lack of supervisory support, and long hours. 


\section{Chapter 3}

\section{Research Methodology}

This chapter presents the methodology of the research study including an overview of the descriptive correlational research design and population under study. The data collection and analysis methods and procedures are addressed, including the online instrument and interviews. Validity of the instruments, data analysis, and limitations of the study are also examined.

\section{Research Design}

The research study utilized a mixed-method research design with methodological triangulation. Methodological triangulation involves using multiples sources and methodologies to find evidence for the study and then comparing the findings from each source with each other (Denzin \& Lincoln, 1992). Utilizing multiple methods in a study through triangulation adds rigor, breadth, and depth to any investigation (Flick, 1992). Gorard and Taylor (2004) argue the importance of combining multiple research methods through a mixed-methods approach when conducting education and social science research. In this study three methods were used: document review of employment trend data at the West Virginia University Extension Service, an online questionnaire for county Extension faculty, and interviews with supervisors of county Extension faculty. Data collection methods were triangulated utilizing document review, questionnaires, and interviews; with corresponding triangulation of sources through organizational records, faculty perceptions, and supervisor perceptions, respectively. This study compares intrinsic and extrinsic motivation factors and discusses the results and significance of correlations with independent variables, including faculty tenure status and generational cohort groups. The study protocol was reviewed and received approval through the WVU Institutional Review Board for the Protection of Human Subjects (Appendix A). 


\section{Population under Study}

A whole study population was implemented for the study. The subjects included all county full-time Extension faculty members employed by West Virginia University Extension Service (WVUES) $(n=107)$. All county Extension faculty members are in WVU's tenure track system and include both tenured and non-tenured members. Each subject works out of one of the 55 county Extension offices in West Virginia.

\section{Data Collection}

In this study, the researcher utilized the following methods:

1) Document review of employment trend data at the West Virginia University Extension Service.

2) An online questionnaire, which included the modified Minnesota Satisfaction Questionnaire (MSQ) Short-Form, open-ended questions on job satisfaction, and questions related to demographics and the respondent's workplace environment (Appendix B).

3) Interviews with supervisors of county Extension faculty from the four program unit areas. These interviews focused on the supervisors' perceptions and experiences supervising faculty in different generational cohorts and with tenure and non-tenure status (Appendix C).

Document review of employment trend data. Document review was conducted on employment trend data at the West Virginia University Extension Service. Data from the office of human resources was utilized to analyze employment trends for five fiscal years from 2008 to 2013. Trends in turnover and hiring were reviewed by gender, generational cohort, tenure status, 
and length of employment based on start and end years. Reasons for departure were not provided to the researcher.

To protect current and past Extension employees, identifying information was removed from the existing records before it was received by the researcher and content analysis was conducted on aggregate data only.

Online questionnaire. A 60-item online questionnaire with three components including a modified Minnesota Satisfaction Questionnaire (MSQ) Short-Form, questions on perceptions of the work environment, and demographics was distributed to county Extension faculty. The modified Minnesota Satisfaction Questionnaire (MSQ) Short-Form, copyright 1977, was used in the first section to assess job satisfaction. Permission to use the copyrighted form was obtained from the University of Minnesota through the Vocational Psychology Research Unit of the Department of Psychology (Appendix D). The MSQ Short-Form consists of 20-items (see Appendix B). The questions are derived from an abbreviated subset of the MSQ Long-Form. The questions are answered with a five-point Likert scale with the following response categories: very dissatisfied (1), dissatisfied (2), neither (3) satisfied (4), and very satisfied (5). The questions on the MSQ Short-Form were grouped together into three indices to measure three constructs as shown in Table 2, twelve questions measure intrinsic satisfaction, six questions measure extrinsic satisfaction, and all twenty questions measure general satisfaction. 


\section{Table 2}

MSQ Short-Form Questions by Intrinsic, Extrinsic, and Total Satisfaction*

Construct $\quad \underline{\text { Scale MSQ Short-Form Questions }}$

Intrinsic $\quad 1,2,3,4,7,8,9,10,11,15,16,20$

Extrinsic $\quad 5,6,12,13,14,19$

General Satisfaction $\quad 1,2,3,4,5,6,7,8,9,10,11,12,13,14,15,16,17,18,19,20$

*From Weiss, Davis, Lofquist, and England, 1967.

The second section of the online questionnaire captured answers to open-ended questions on perceptions of the work environment including facilities, peer relationships, supervision, motivations, and advancement (Appendix B).

The third and last section of the online questionnaire collected unidentifiable demographic information about the subjects. These questions included year of birth, gender, faculty tenure and non-tenure status, number of program areas served, years of service, significant contribution areas for tenure and promotion (teaching and research or service), and other personal commitments. There were also questions about the respondent's work environment including average number of hours worked per week, overnights away from home per year, number of direct contacts, number of people supervised, and percent of time spent per year on teaching/research/service (Appendix B).

The online questionnaire was created in Qualtrics, a web-based survey tool. The online questionnaire was implemented in December 2013 and the subjects, county-based faculty members, were notified via email. Survey participants followed an anonymous uniform resource locator (URL) link to complete the survey. In the email, the subjects were told they were not required to participate in the study, their participation was voluntary, and their responses to the 
online survey were anonymous and confidential (Appendix E). All identifying information was scrubbed when the responses were saved in Qualtrics, including Internet Protocol (IP) addresses. Follow-up reminders were distributed at fourteen and twenty-one days from initial solicitation.

Interviews with supervisors of county Extension faculty. Interviews were conducted with supervisors of county Extension faculty from four program unit areas: Agriculture and Natural Resources; Families and Health; Community, Economic, and Workforce Development; and 4-H Youth Development. The purpose of the interviews was to learn about the perceptions and experiences of unit directors as they supervise faculty members in three generational cohorts and two tenure statuses. Semi-structured interview questions were based on Herzberg's Motivation-Hygiene Theory factors (Appendix C). The supervisors received a cover letter via email requesting their participation, and were notified they were not required to participate in the study and that their participation was voluntary (Appendix F).

The researcher conducted the interviews in December 2013 and January 2014. Each program unit was represented, for a total of four interviews. Interviews were completed online in GoToMeeting website software, utilizing an audio recording file. Each interview took approximately 45 minutes to complete. Interviews were transcribed verbatim and no names of individuals interviewed were entered into the transcription.

\section{Analysis of Data}

This study used a descriptive correlational design that evaluated the differences of job satisfaction as measured by the MSQ Short-Form, including an analysis of intrinsic/extrinsic factors based on the Herzberg work motivation theory, and then correlated the results with independent variables. The most important independent variables for this study were generational cohort and faculty status. Other independent variables including age, gender, and 
educational background were also correlated with intrinsic, extrinsic, and overall job satisfaction factors.

According to Deutskens, Ruyter, Wetzels, and Oosterveld (2004) response rates to a long version online survey, which is more than twenty questions, are usually around 17 percent. A $25 \%$ target response rate was selected ahead of the study because of the vested interest of the study participants in the results of the study.

Table 3 provides an overview of research questions with respect to study variables, data analysis methods, and instrument items.

\section{Table 3}

Research Questions by Variables, Data Analysis Method, and Instrument Items

\begin{tabular}{|l|l|l|l|l|}
\hline Number & $\begin{array}{l}\text { Research Question } \\
\text { (Independent/Dependent) }\end{array}$ & $\begin{array}{l}\text { Data } \\
\text { Analysis } \\
\text { Method }\end{array}$ & $\begin{array}{l}\text { Instrument } \\
\text { Items }\end{array}$ \\
\hline 1. & $\begin{array}{l}\text { What is the demographic } \\
\text { profile (gender, } \\
\text { generational cohort based } \\
\text { on year of birth, tenure } \\
\text { status, academic rank, area } \\
\text { of significance, [T/R or } \\
\text { T/S], program area served, } \\
\text { and years of service) of } \\
\text { county Extension faculty } \\
\text { in West Virginia? }\end{array}$ & $\begin{array}{l}\text { Nescriptive } \\
\text { statistics for } \\
\text { demographic } \\
\text { questions }\end{array}$ & $\begin{array}{l}\text { Online } \\
\text { questionnaire } \\
\text { (section 3), } \\
\text { Document } \\
\text { review }\end{array}$ \\
\hline 2. & $\begin{array}{l}\text { What is the work } \\
\text { environment profile of } \\
\text { county Extension faculty } \\
\text { in West Virginia (average } \\
\text { number of hours worked a } \\
\text { week, number of } \\
\text { overnights away from } \\
\text { home per year, number of } \\
\text { direct contacts, number of } \\
\text { people supervised, and } \\
\text { percent of time spent per }\end{array}$ & N/A & $\begin{array}{l}\text { Descriptive } \\
\text { statistics for } \\
\text { work } \\
\text { environment } \\
\text { questions }\end{array}$ & $\begin{array}{l}\text { Online } \\
\text { questionnaire } \\
\text { (section 3) }\end{array}$ \\
\hline
\end{tabular}




\begin{tabular}{|c|c|c|c|c|}
\hline & $\begin{array}{l}\text { year on } \\
\text { teaching/research/service)? }\end{array}$ & & & \\
\hline 3. & $\begin{array}{l}\text { What is the overall job } \\
\text { satisfaction among county } \\
\text { Extension faculty? }\end{array}$ & $\begin{array}{l}\text { Independent variable = } \\
\text { county Extension faculty } \\
\text { Dependent variable = } \\
\text { mean on index of all job } \\
\text { satisfaction questions }\end{array}$ & $\begin{array}{l}\text { Descriptive } \\
\text { statistics of } \\
\text { job } \\
\text { satisfaction } \\
\text { questions } \\
\text { and } \\
\text { qualitative } \\
\text { analysis of } \\
\text { open-ended } \\
\text { questions }\end{array}$ & $\begin{array}{l}\text { Online } \\
\text { questionnaire } \\
\text { (sections } 1 \\
\text { and 2) }\end{array}$ \\
\hline 4. & $\begin{array}{l}\text { Are county Extension } \\
\text { faculty members more } \\
\text { intrinsically or } \\
\text { extrinsically motivated? }\end{array}$ & $\begin{array}{l}\text { Independent variable = } \\
\text { county Extension faculty } \\
\text { Dependent variables = } \\
\text { Mean on intrinsic work } \\
\text { factors and } \\
\text { mean on intrinsic work } \\
\text { factors }\end{array}$ & $\begin{array}{l}\text { Chi-square } \\
\text { and T-test }\end{array}$ & $\begin{array}{l}\text { Online } \\
\text { questionnaire } \\
\text { (section 1) }\end{array}$ \\
\hline 5. & $\begin{array}{l}\text { Is there a correlation } \\
\text { between the overall level } \\
\text { of job satisfaction of } \\
\text { county Extension faculty, } \\
\text { and intrinsic and extrinsic } \\
\text { work factors? }\end{array}$ & $\begin{array}{l}\text { Independent variable = } \\
\text { Mean on overall job } \\
\text { satisfaction } \\
\text { Dependent variables = } \\
\text { Mean on intrinsic work } \\
\text { factors and } \\
\text { mean on intrinsic work } \\
\text { factors }\end{array}$ & Chi-square & $\begin{array}{l}\text { Online } \\
\text { questionnaire } \\
\text { (section 1) }\end{array}$ \\
\hline 6. & $\begin{array}{l}\text { Are there differences } \\
\text { between generational } \\
\text { cohorts and faculty tenure } \\
\text { and non-tenure status on } \\
\text { general job satisfaction, } \\
\text { intrinsic job satisfaction, } \\
\text { and extrinsic job } \\
\text { satisfaction among county } \\
\text { Extension faculty? }\end{array}$ & $\begin{array}{l}\text { Independent variables = } \\
\text { county Extension faculty } \\
\text { in each of the } \\
\text { generational cohorts } \\
\text { Dependent variables = } \\
\text { mean scores on indices } \\
\text { of general, intrinsic, and } \\
\text { extrinsic job satisfaction. }\end{array}$ & $\begin{array}{l}\text { Chi-square } \\
\text { analysis } \\
\text { Qualitative } \\
\text { analysis of } \\
\text { open-ended } \\
\text { questions on } \\
\text { online } \\
\text { survey and } \\
\text { supervisor } \\
\text { interview } \\
\text { data }\end{array}$ & $\begin{array}{l}\text { Online } \\
\text { questionnaire } \\
\text { (sections } 1 \\
\text { and 2) } \\
\text { Interviews } \\
\text { with } \\
\text { supervisors. }\end{array}$ \\
\hline
\end{tabular}


Research questions one and two. The population and work environments were described using descriptive analyses of demographic and workplace data. Document review analysis was completed on West Virginia University Extension Service employment trend data provided by the human resources office. Analysis was completed on the number of county Extension faculty that left between the fiscal years 2008 and 2013. A profile was compiled including demographics on gender, generational cohort, whether or not tenure status had been achieved, and number of years employed.

Through answers provided on the online questionnaire, a demographic profile including gender, generational cohort based on year of birth, tenure status, academic rank, area of significant contribution for tenure and promotion (teaching and research or service), work unit, and years of service was generated. A work environment profile was generated using the average number of hours worked per week, number of overnights away from home per year, number of direct contacts, number of people supervised, professional development needs and activities, and percent of time spent in teaching, research, and service.

Research questions three, four, and five. A five-step quantitative analysis of the modified MSQ Short-Form survey and demographic/work environment questions was conducted to examine faculty job satisfaction. The quantitative data from the MSQ was organized and analyzed using Statistical Package for the Social Sciences, Version 20 (IBM SPSS 20).

To create the three motivational indices: intrinsic, extrinsic and general satisfaction, the scores for each individual variable in the construct were added together, then the scores were recoded into new categories based on the 1 to 5 scale established for the individual questions. These new categories represented a range of scores that is not a perfect measure because scores may land close to one cutoff line or another; however a choice had to be made as to which point 
in the range it would be assigned. For example, with the intrinsic motivation variable, cumulative scores ranging from 1 to 18 equal 1, scores of 19-30 equal 2, scores of 31-42 equal 3, scores of 43-54 equal 4, and scores of 55-60 equal 5. A score of 18 would be the equivalent of a measure that equaled 1.5 , while 19 would equal 1.6 and be closer to 2 .

1. Frequencies and descriptive were examined for each question on the MSQ part of the questionnaire.

2. A general job satisfaction rating was calculated by creating an index which included all of the variables in the MSQ related to job satisfaction.

3. Variables were combined into two addition indices based on the constructs intrinsic and extrinsic satisfaction.

4. Overall means for each construct were generated and compared with each other using a chi square analysis.

5. Other independent variables were examined to see if there was a correlation with general job satisfaction, and intrinsic and extrinsic job satisfaction. These variables included generational cohort, tenure status, gender, years in Extension, hours worked, satisfaction with supervision level, and satisfaction with recognition and award. Depending on the variable, appropriate statistical tests were selected including chi square, analysis of means, and regression analysis.

Research question six. The final research question was answered by analyzing data from both the MSQ section of the questionnaire and the interviews with supervisors. NVivo 10, a qualitative research software program, was utilized for content analysis of qualitative responses on open-ended questions from the online survey and interview transcripts. The NVivo 10 software program was selected on its' ability to assist the researcher in managing data and ideas, 
providing query data, graphically models, and reports from data (Bazeley, 2009). Qualitative data was analyzed using axial coding to "fracture" the data and to reassemble it in new ways (Krueger, 1994, 128; Strauss and Corbin 1990, 61-74, 96-115). The first step was to compare the data to decide which data belonged together. This was often done through "in vivo" coding when the actual language of the respondent was used as a code name (Harry, Sturges, and Klingner 2005, 5). Codes were then clustered into selected groups determined on how they related to each other (Strauss and Corbin, 1990). As the researcher came across discrete codes they were labeled into the conceptual categories of intrinsic, extrinsic, or overall satisfaction. Matrix coding queries were then completed in NVivo 10 for the attributes of tenure status and generational cohort to determine ideas or phenomenon.

\section{Validity and Reliability}

For the Minnesota Satisfaction Questionnaire (MSQ) Short-Form, the Hoyt reliability coefficients for each of the constructs are as follows: intrinsic satisfaction $=0.86$, extrinsic satisfaction $=0.80$, and general satisfaction $=0.90$ (Weiss, Davis, Lofquist, \& England, 1967) . High validity coefficients were established from studies of a variety of occupational groups (Weiss, et. al., 1967).

For the online questionnaire a pilot study was not conducted to measure test reliability. However, the online questionnaire of demographic and open-ended questions underwent cognitive review with Extension personnel to ensure the questionnaire measures concepts familiar to the research subjects. Extension faculty completed the review at Galaxy IV, a national conference for Extension educators in September 2013. The conference, which is held every five years by the Joint Council of Extension Professionals (JCEP), provides professional development for the entire Extension System. Ten individuals working in the areas of 4-H youth 
development; community, economic and workforce development; and family consumer sciences completed the cognitive review. These individuals were from the following states: Florida, Indiana, New York, Ohio, Oklahoma, Pennsylvania, and Wyoming.

The purpose of the review was to determine if the online questionnaire questions was easily understood by county faculty in other states in order to determine if the researcher needed to make modifications. Cognitive review participants were asked to read the instructions and review all of the questions for clarity. They provided responses and gave feedback (Appendix G). Overall results of the cognitive review were positive. Recommendations included:1) more clearly define the terms "direct contacts " and "significant interpersonal relationships, " and 2) review options to shorten or assure the questionnaire could be completed in a shorter amount of time. In addition, some technical malfunctions with responding to the survey in Qualtrics were detected and resolved. Adjustments were made as appropriate based on cognitive review responses.

To ensure clarification and reliability of qualitative data a research consultant, an expert in the field of qualitative research, was employed (Appendix H). The established code book and coded data were reviewed by the research consultant. A constant comparison method was utilized, in which data was compared to see if the same code would apply according to the research consultant, developing consistency in the usage of codes (Harry, Sturges, and Klingner, 2005). No attempt was made to develop a numerical reliability rating, due to a consensus between the researcher and research consultant.

\section{Limitations of Research Design}

Study limitations clarify the scope and boundaries of study (Creswell, 2009; Roberts, 2004). One limitation of the study was that participants for this study included only county 
faculty educators from the West Virginia University Extension Service. Other types of faculty members such as specialists were not included and other Extension systems were not surveyed. The results of this study cannot be generalized to other Extension systems or to other types of higher education faculty.

Another limitation of the study was that the researcher is a member of WVUES county faculty and is located at a county level office. Although her responsibilities are different from most county faculty members because she assists in administrating a statewide literacy program and does not have the roles and responsibilities of county-level faculty, she has functioned as a county Extension faculty member at other times in her career. She acknowledges a work relationship with the subjects in this study.

A third limitation to the study was the reasons for departure of county Extension faculty were not provided in the employment trend data to the researcher. Had this information been made available, it could have provided greater insight into intrinsic and extrinsic motivations of county Extension faculty.

A fourth limitation to the study is researcher bias. The researcher has attended workshops on generation differences and taught multiple conferences and workshops on the subject.

\section{Summary}

The mixed-methods study utilized methodological triangulation. Data collection included document review of employment trend data, an online questionnaire completed with county Extension faculty, and interviews conducted with supervisors of county Extension faculty. The study assessed overall job satisfaction, compared intrinsic and extrinsic job 
satisfaction factors, and included two major independent variables of generational cohorts and tenure status. Validity and reliability of quantitative and qualitative data was established. 


\section{Chapter Four}

\section{Results}

This research study assessed the job satisfaction of county-based faculty employed with the West Virginia University Extension Service. The study used the Herzberg MotivationHygiene Theory as a basis for analysis. In addition to overall job satisfaction, the study assessed the intrinsic and extrinsic job satisfaction by generational cohort, faculty status, and other relevant characteristics of the subjects.

Three sources of data were used in the analysis:

1. Document review on employment trend data of the West Virginia University Extension Service for the fiscal years of 2008 to 2013.

2. An online questionnaire for assessment of faculty demographic profile, work environment profile, and job satisfaction. A total of 79 out of 107 county-based Extension faculty members completed the survey, which resulted in a $73.8 \%$ response rate.

3. Four interviews with the supervisors of the county-based faculty. This chapter addresses the findings of the research questions. The research questions for this study are:

1. What is the demographic profile (gender, generational cohort based on year of birth, tenure status, academic rank, area of significance [teaching and research or teaching and service], number of program areas served, and years of service) as a county Extension faculty member in West Virginia?

2. What is the work environment profile of county Extension faculty in West Virginia (average number of hours worked a week, number of overnights away from home per 
year, number of direct contacts, number of people supervised, and percent of time spent per year on teaching/research/service)?

3. What is the overall job satisfaction among county based Extension faculty?

4. Are county Extension faculty more intrinsically motivated or extrinsically motivated?

5. Is there a correlation between the overall level of job satisfaction of county Extension faculty, and intrinsic and extrinsic work factors?

6. Are there differences between generational cohorts and faculty tenure and non-tenure status on overall job satisfaction, intrinsic job satisfaction, and extrinsic job satisfaction among county Extension faculty?

\section{Research Question One: Demographic Profile}

The subjects for this research study included all county-based Extension faculty members employed by the by West Virginia University Extension Service (WVUES) ( $n=107)$. All county faculty members are in WVU's tenure track system and include both tenured and non-tenured members. The study population consisted of a total of 107 county Extension faculty members, 46 males and 61 females. County-based faculty members work in one of WVUES four programs units: 4-H Youth Development (N=42), Families and Health $(\mathrm{N}=20)$, Agriculture and Natural Resources ( $\mathrm{N}=36)$, and Community, Economic, and Workforce Development $(\mathrm{N}=9)$. There were 79 usable responses from the total population of 107 county Extension faculty members.

Gender. As seen in Table 4, the Extension Service is composed of 57.0 percent female and 43.0 percent male. The response rates were consistent with the gender population of the WVU Extension Service. Males completing the survey represented 38.0 percent of the respondents and females represented 62.0 percent of the respondents. 


\section{Table 4}

Gender

\begin{tabular}{lcccc}
\hline & $\underline{\mathrm{N}}$ & $\underline{\text { \% of population }}$ & $\underline{\mathrm{n}}$ & \% of respondents \\
Male & 46 & 43.0 & 30 & 38.0 \\
Female & 61 & 57.0 & 49 & 62.0 \\
\hline Total & 107 & 100 & 79 & 100 \\
\hline
\end{tabular}

Generational cohort. Respondents were asked to identify their generational cohort by selecting the time period in which they were born. Options, as shown in Table 5, were before 1946 (Pre-Baby Boomers), 1946-1964 (Baby Boomers), 1965-1979 (Generation X), and 19802000 (Millennials). The largest number of respondents, 40.5 percent, were Generation X, followed by Baby Boomers (31.6\%), and Millennials (25.3\%). Two respondents did not answer this question. The variance between groups was .588.

\section{Table 5}

Generational Cohort

\begin{tabular}{lcc}
\hline & $\underline{\mathrm{n}}$ & $\underline{\%}$ \\
Pre-Baby Boomers (Before 1946) & 0 & 0.0 \\
Baby Boomers (1946-1964) & 25 & 31.7 \\
Generation X (1965-1979) & 32 & 40.5 \\
Millennials (1980-2000) & 20 & 25.3 \\
Missing & 2 & 2.5 \\
\hline Total & 79 & 100 \\
\hline
\end{tabular}


Faculty status. As shown in Table 6, a majority of respondents had tenure with 54.4 percent tenured and 43.0 of respondents untenured. Since all WVU county Extension agents are eligible for tenure in six years, those who answered untenured most likely have not yet reached their sixth year. Two respondents did not answer this question.

\section{Table 6}

\section{Faculty Status: Tenure/Non-tenure Status}

\begin{tabular}{lll}
\hline & $\underline{\mathrm{n}}$ & $\underline{\%}$ \\
Yes & 43 & 54.4 \\
No & 34 & 43.0 \\
Missing & 2 & 2.5 \\
\hline Total & 79 & 100 \\
\hline
\end{tabular}

Academic rank. Most Extension agents are hired at the instructor level, with a master's degree required. There are some exceptions, however. Although it is rare, previous experience in Extension is sometimes considered and a newly hired Extension agent is granted the title of Extension assistant professor at the time of hiring. In Table 7, respondents at the Extension Instructor level represented 39.2 percent of the respondents. The second largest category was Extension Assistant Professor at 32.9 percent, followed by Extension Associate Professor with 26.6 percent. None of the respondents were at the highest rank of Extension Professor. One respondent did not answer this question. 


\section{Table 7}

Academic Rank

\begin{tabular}{lll}
\hline & $\underline{\mathrm{n}}$ & $\underline{\%}$ \\
Extension Instructor & 31 & 39.2 \\
Extension Assistant Professor & 26 & 32.9 \\
Extension Associate Professor & 21 & 26.6 \\
Extension Professor & 0 & 0.0 \\
Missing & 1 & 1.3 \\
\hline Total & 79 & 100 \\
\hline
\end{tabular}

Significant areas of contribution. Every county Extension faculty member has two areas of significance. The first is teaching, and the second is either research or service. County Extension faculty who were employed before 2003 are most likely to have research as their second area of contribution unless they requested a change to their assignment. Since 2003, almost all West Virginia University county faculty are assigned service as their second significant area.

As shown in Table 8, the majority of respondents reported service $(82.3 \%)$ as their second major area of significance, and $16.5 \%$ of respondents reported research as their second area of significance. One respondent did not answer this question. 


\section{Table 8}

Area of Significance in Addition to Teaching

\begin{tabular}{lcc}
\hline & $\underline{\mathrm{n}}$ & $\underline{\%}$ \\
Research & 13 & 16.5 \\
Service & 65 & 82.3 \\
Missing & 1 & 1.3 \\
\hline Total & 79 & 100 \\
\hline
\end{tabular}

Program areas. In the Extension Service there are four units which are similar in structure to departments within other WVU colleges. These units are: 4-H and Youth Development, Agricultural and Natural Resources, Families and Health, and Community and Economic Workforce Development. The response rates are consistent with the size of the WVU Extension Service units. As illustrated in Table 9, of the four units, 4-H and Youth Development is the largest with 43 faculty members. In this survey, the largest group of respondents (41.8\%) was from the 4-H Youth Development, followed by Agricultural and Natural Resources (29.1\%), and then Families and Health (21.5\%). As the smallest unit, with a total of 7 faculty, Community and Economic Workforce Development had a correspondingly small response rate of 7.6\% or with 6 faculty. This result is consistent with the makeup of the WVU Extension Service units. 


\section{Table 9}

Primary Program Area

\begin{tabular}{|c|c|c|c|c|}
\hline & $\underline{\mathrm{N}}$ & $\begin{array}{c}\% \text { of } \\
\text { population }\end{array}$ & $\underline{\mathrm{n}}$ & $\begin{array}{c}\% \text { of } \\
\text { respondents }\end{array}$ \\
\hline Agriculture and Natural Resources & 35 & 32.7 & 23 & 29.1 \\
\hline Families and Health & 22 & 20.6 & 17 & 21.5 \\
\hline 4-H Youth Development & 43 & 40.2 & 33 & 41.8 \\
\hline Community and Economic Workforce Development & 7 & 6.5 & 6 & 7.6 \\
\hline Total & 107 & 100 & 79 & 100 \\
\hline
\end{tabular}

Years of service. New employees with five years of service or less made up the majority of respondents (32.9\%), as shown in Table 10. The second largest group of respondents (22.8\%) were those who have worked for Extension for six to 10 years. Only three (3.8\%) of the respondents said they had worked for Extension for 31 to 40 years.

\section{Table 10}

Years of Service

\begin{tabular}{lll}
\hline & $\underline{\mathrm{n}}$ & $\underline{\%}$ \\
$0-5$ & 26 & 32.9 \\
$6-10$ & 18 & 22.8 \\
$11-20$ & 16 & 20.3 \\
$21-30$ & 11 & 13.9 \\
$31-40$ & 3 & 3.8 \\
Missing & 5 & 6.3 \\
\hline Total & 79 & 100 \\
\hline
\end{tabular}


Document Review. Document review was conducted on a five-year employment trend data of the West Virginia University Extension Service. From the fiscal year beginning in 2008 to 2013, 45 county-based Extension faculty left the Extension Service. There was an even balance in gender of 21 males and 24 females. The largest number of county faculty left in 2008-2009, which was 14. Twenty-nine county faculty left the Extension Service before they had completed 10 years of work, with one employee having served only one week. In comparison, the employee serving the longest worked for 44 years. Tenure had been received by 18 faculty members before they left, while 27 had not yet received tenure. When assessing generational cohorts it was determined that five individuals were Pre-Baby Boomers, seventeen were Baby Boomers, fifteen were Generation X'ers, and eight were Millennials.

\section{Research Question Two: Work Environment Profile}

Average number of hours worked per week. Table 11 illustrates that when asked about the average number of hours worked per week the largest number of respondents (32.9\%) indicated they worked an average of 46 to 50 hours per week, followed by 41 to 45 hours per week (31.6\%). According to the West Virginia University Extension Service (n.d.) the standard number of hours for West Virginia University full-time employees is 37.5 hour a week, but only $12.7 \%$ of respondents indicated they worked 0 to 40 hours per week. One respondent did not complete the question. 


\section{Table 11}

Average Number of Hours Worked Per Week

\begin{tabular}{lll}
\hline & $\underline{\mathrm{n}}$ & $\underline{\%}$ \\
$0-40$ & 10 & 12.7 \\
$41-45$ & 25 & 31.6 \\
$46-50$ & 26 & 32.9 \\
$51-55$ & 9 & 11.4 \\
$56-60$ & 7 & 8.9 \\
$61-65$ & 1 & 1.3 \\
Missing & 1 & 1.2 \\
\hline Total & 79 & 100 \\
\hline
\end{tabular}

Average number of nights away from home per year. An expectation of county Extension faculty is they will travel overnight as needed to complete their job assignment. Outof-town activities are related to professional development, teaching, research, and service. As shown in Table 12, the largest percentage of respondents (34.2\%) indicated that on average they spent 15 to 21 nights away from home per year to complete their job assignments. The second largest response (22.8\%) was 22 to 28 nights per year, followed by 8 to $14(17.7 \%)$ nights away from home per year. Results in Table 12 are organized in multiples of seven nights or one week. The results indicate 57 percent of respondents spend between three to four weeks a year away from home for job responsibilities. 
Table 12

Average Number of Nights Away From Home per Year

\begin{tabular}{lrc} 
& $\underline{\mathrm{n}}$ & $\underline{\%}$ \\
$0-7$ & 5 & 6.3 \\
$8-14$ & 14 & 17.7 \\
$15-21$ & 27 & 34.2 \\
$22-28$ & 18 & 22.8 \\
$29-35$ & 9 & 11.4 \\
$36-42$ & 3 & 3.8 \\
$43-49$ & 1 & 1.3 \\
Missing & 2 & 2.5 \\
\hline Total & 79 & 100 \\
\hline
\end{tabular}

Average number of direct contacts per year. Respondents were asked to provide their average number of direct contacts per year. Direct contacts was defined as individuals with whom they interact directly through phone calls, workshops, or seminars. Direct contacts do not include distribution through mass or social media. Table 13 shows the largest grouping, more than a third of the respondents $(35.4 \%)$, was zero to 999 contacts per year. This was followed by $(22.8 \%)$ with 1,000 to 1,999 direct contacts per year. There was one outlier from a respondent who indicated he/she had an average of 9,001 to 10,000 direct contacts per year. Eight respondents did not answer this question. Perhaps this was due to the question being unclear to respondents. 


\section{Table 13}

Average Number of Direct Contacts per Year

\begin{tabular}{lll}
\hline & $\underline{\mathrm{n}}$ & $\underline{\%}$ \\
$0-999$ & 28 & 35.4 \\
$1,000-1,999$ & 18 & 22.8 \\
$2,000-2,999$ & 13 & 16.5 \\
$3,000-3,999$ & 4 & 5.1 \\
$4,000-4,999$ & 3 & 3.8 \\
$5,000-5,999$ & 2 & 2.5 \\
7,000 & 2 & 2.5 \\
10,000 & 1 & 1.3 \\
Missing & 8 & 10.1 \\
\hline Total & 79 & 100 \\
\hline
\end{tabular}

Number of people supervised. Respondents were asked about the number of people they supervised in their local county offices. This would include positions such as secretaries, program assistants, and nutrition outreach instructors. As seen in Table 14, responses ranged from one to six individuals, with one outlier from a respondent indicated s/he supervised 26 people. The highest response was two with 36.7 percent, followed by one with 22.8 percent. Eleven respondents indicated they did not supervise anyone in their offices. Five respondents did not answer this question. 


\section{Table 14}

Number of People Supervised

\begin{tabular}{lcc}
\hline & $\underline{\mathrm{n}}$ & $\underline{\%}$ \\
0 & 11 & 13.9 \\
1 & 18 & 22.8 \\
2 & 29 & 36.7 \\
3 & 8 & 10.1 \\
4 & 5 & 6.3 \\
6 & 2 & 2.5 \\
26 & 1 & 1.3 \\
Missing & 5 & 6.3 \\
\hline Total & 79 & 100 \\
\hline
\end{tabular}

Percent of time spent per year on teaching, research, and service. The majority of respondents reported their areas of significant contribution were teaching and service. The average percent of time spent in each area, as reported by respondents, was 37.3 on teaching, 15.6 on research, and 47.2 on service. The largest majority of respondents indicated they spend 40 percent of their time on teaching, 10 percent of the time on research, and between 40 to 50 percent of their time on service.

As indicated in Table 8, 16.5 percent of the respondents had research as their second area of significant contribution in contrast to service for 82.3 percent of respondents. Tables 15,16 , and 17 were created based on the assumption that an average faculty member spends 40 percent on their areas of significant contribution and 20 percent on their area of reasonable contribution. 
In teaching 45.6 percent of respondents indicated they spent less than 40 percent on teaching, and 54.4 percent spent more than 40 percent on teaching per year. In the area of research 60.8 percent said they spent less than 20 percent on research, and 39.2 percent said they spent more than 20 percent on research. Lastly, in the area of service 10.1 percent on average spent less than 40 percent of their work in the area of service as compared to 89.9 percent who completed 40 percent or more on service.

\section{Table 15}

Percent of Time Spent per Year on Teaching

\begin{tabular}{lll}
\hline & $\underline{\mathrm{n}}$ & $\underline{\%}$ \\
Less than $40 \%$ & 36 & 45.6 \\
$40 \%$ or more & 43 & 54.4 \\
\hline Total & 79 & 100 \\
\hline
\end{tabular}

\section{Table 16}

Percent of Time Spent per Year on Research

\begin{tabular}{lll}
\hline & $\underline{\mathrm{n}}$ & $\underline{\%}$ \\
Less than $20 \%$ & 48 & 60.8 \\
$20 \%$ or more & 31 & 39.2 \\
\hline Total & 79 & 100 \\
\hline
\end{tabular}


Table 17

Percent of Time Spent per Year on Service

\begin{tabular}{lcl}
\hline & $\underline{\mathrm{n}}$ & $\underline{\%}$ \\
Less than $40 \%$ & 8 & 10.1 \\
$40 \%$ or more & 71 & 89.9 \\
\hline Total & 79 & 100 \\
\hline
\end{tabular}

\section{Research Question Three: Overall Job Satisfaction}

The Minnesota Satisfaction Questionnaire (MSQ) Short-Form was used to measure job satisfaction of West Virginia University Extension Service county faculty. The MSQ ShortForm consists of 20 Likert-scale items which measure general job satisfaction, and intrinsic and extrinsic satisfaction. Table 18 provides the mean and standard deviation for each of the MSQ Short-Form 20-item questions. The means and standard deviations ranged from 2.94 to 4.78, and 0.503 to 1.255 respectively. The low was 2.94 for the MSQ question "My pay and the amount of work I do." The highest mean was 4.78 for MSQ questions "The chance to do different things from time to time" and "The chance to do things for other people."

\section{Table 18}

\section{MSQ Short-Form Means and Standard Deviations}

Question

Being able to keep busy all the time

The chance to work alone on the job

The chance to do different things from time to time

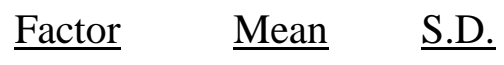

Intrinsic $\quad 4.44 \quad 0.693$

Intrinsic $\quad 4.42 \quad 0.633$

Intrinsic $\quad 4.78 \quad 0.523$ 


\section{Table 18 Continued}

Question

The chance to be "somebody" in the community

The competence of my supervisor in making decisions

The way my supervisor handles his/her employees

Being able to do things that don't go against my conscience

The way my job provides for steady employment

The chance to do things for other people

The chance to tell people what to do

The chance to do something that makes use of my abilities

The way organizational policies are put into practice

My pay and the amount of work I do

The chances for advancement on this job

The freedom to use my own judgment

The chance to try my own methods of doing the job

The working conditions

The way my co-workers get along with each other

The praise I get for doing a good job

The feeling of accomplishment I get from the job

\begin{tabular}{|c|c|c|}
\hline Factor & $\underline{\text { Mean }}$ & $\underline{\text { S.D. }}$ \\
\hline Intrinsic & 4.24 & 0.788 \\
\hline Extrinsic & 3.61 & 1.255 \\
\hline Extrinsic & 3.91 & 1.157 \\
\hline Intrinsic & 4.34 & 0.732 \\
\hline Intrinsic & 4.57 & 0.710 \\
\hline Intrinsic & 4.78 & 0.443 \\
\hline Intrinsic & 3.58 & 0.814 \\
\hline Intrinsic & 4.47 & 0.596 \\
\hline Extrinsic & 2.97 & 0.974 \\
\hline Extrinsic & 2.94 & 1.030 \\
\hline Extrinsic & 3.19 & 0.948 \\
\hline Intrinsic & 4.49 & 0.503 \\
\hline Intrinsic & 4.48 & 0.596 \\
\hline Neither & 4.10 & 0.794 \\
\hline Neither & 4.05 & 1.011 \\
\hline Extrinsic & 3.53 & 1.036 \\
\hline \multirow[t]{2}{*}{ Intrinsic } & 4.37 & 0.664 \\
\hline & 4.09 & 0.511 \\
\hline
\end{tabular}

General Job Satisfaction

Respondents completed the Minnesota Job Satisfaction (MSQ) Short-Form. For each of the 20items respondents answered either 1=Very dissatisfied, 2=Dissatisfied, 3=Neutral, 4=Satisfied, or 5=Very satisfied (Copyright 1977, Vocational Psychology Research). 
The MSQ Short-Form general satisfaction results had a mean of 4.08, which falls near the category of satisfied on the five-point scale from 1 "very dissatisfied" to 5 "very satisfied". The standard deviation was .511. The combined 20-items on the MSQ that constitutes the general job satisfaction had a Cronbach's Alpha of .840 .

To establish the general job satisfaction score the MSQ Short-Form 20-items were combined into one indice with each individual variable in the construct added together. The scores were then recoded into a new variable with the same one to five scale that was used in the individual questions. The frequencies for the general job satisfaction variable are included in Table 19, which show $73.4 \%$ of respondents were 'satisfied' with their job.

\section{Table 19}

\section{General Job Satisfaction Frequency Distribution}

\begin{tabular}{lcc}
\hline & $\underline{\mathrm{n}}$ & $\underline{\%}$ \\
Very Dissatisfied & 0 & 0 \\
Dissatisfied & 0 & 0 \\
Neutral & 7 & 8.9 \\
Satisfied & 58 & 73.4 \\
Very Satisfied & 14 & 17.7 \\
\hline Total & 79 & 100 \\
\hline
\end{tabular}

The study focused on two variables for analysis in relation to job satisfaction: generational cohorts and tenure status. A cross-tabulation analysis did not reveal any relationship between general job satisfaction and generational cohorts (value $=3.599 ; \underline{p}>.05$ ). In 
addition, a Pearson chi-square analysis did not reveal any significant relationship between general job satisfaction and tenure status (value $=.928 ; \mathrm{p}>.05)$.

Other variables were also examined to assess their relationship to general job satisfaction, and Table 20 illustrates two variables showed significant results. A cross-tabulation analysis revealed a significant relationship between general job satisfaction and the recognition of work (value $=7.390 ; \underline{p}<.025)$. A majority of those who said they received adequate recognition for their work also said they were very satisfied with their job overall. A cross-tabulation analysis also revealed a significant relationship between general job satisfaction and the adequacy of supervision received (value $=8.654 ; \underline{p}<.02)$. Similarly, a majority of those who said they received adequate supervision, also said they were very satisfied with their job overall.

Table 20

Cross-Tabulation between General Job Satisfaction and Ordinal and Nominal Variables

Variable Chi-Square

Generational Cohort

Tenure Status .925

Recognition of Work $7.390^{*}$

Adequacy of Supervision Received $8.654 * *$

Adequacy of Salary 4.087

Gender

Area of Significant Contribution

Academic Rank

Program Area 5.885

$* \mathrm{p}=<.05, * * \mathrm{p}=<.02$ 
Other variables were also assessed that showed no significant outcome as shown in Table 21. A cross-tabulation was conducted on general job satisfaction and the following variables: adequacy of salary, gender, academic rank, area of significant contribution, and program area. The analysis did not reveal any relationship between general job satisfaction and these variables (p-value >.05). In addition to cross-tabulation, regression analysis was also conducted on scaled variables. Using regression analysis, the dependent variable was the index of general job satisfaction and the independent variables were number of people supervised, average number of direct contacts, average number of overnights away from home, average number of hours worked in a typical week, and number of years working for the extension service. The regression analysis conducted between general job satisfaction and the independent variables did not reveal any significant relationships (p-value>.05).

\section{Table 21}

\section{Regression Analysis between General Job Satisfaction and Ratio Variables}

Variable R Square

Number of People Supervised $\quad .015$

Average Number of Direct Contacts $\quad .009$

Number of Overnights Away from Home $\quad .015$

Number hours worked in Typical Weeks $\quad .019$

Number of Years Worked in Extension Service .002

\section{Research Question Four: More Intrinsically or Extrinsically Motivated}

Table 22 illustrates a Pearson Chi-Square analysis was used to assess a relationship between intrinsic and extrinsic job satisfaction of county-based Extension faculty members. The 
analysis revealed a significant difference between intrinsic job satisfaction and extrinsic job satisfaction (value $=19.209 ; \mathrm{p}<.014)$. As shown in the table intrinsic job satisfaction had a higher mean of 4.39 than extrinsic job satisfaction of 3.25. In addition, a paired samples t-test was run to compare the mean intrinsic and extrinsic MSQ scores, which showed a two-tailed significance $(\mathrm{t}=14.24, \mathrm{p}=0.00)$.

Table 22

MSQ Short-Form Job Satisfaction Scores

\begin{tabular}{llccc}
\hline $\begin{array}{c}\text { Satisfaction } \\
\text { Scores }\end{array}$ & Mean & $\begin{array}{c}\text { Standard } \\
\text { Error }\end{array}$ & $\begin{array}{c}\text { Standard } \\
\text { Deviation }\end{array}$ & $\begin{array}{c}\text { Cronbach's } \\
\text { Alpha }\end{array}$ \\
\hline Intrinsic & 4.3924 & .05815 & .51684 & .812 \\
Extrinsic & 3.2532 & .08728 & .77573 & .795 \\
General & 4.0886 & .05751 & .51115 & .840 \\
\hline
\end{tabular}

Intrinsic calculated from MSQ questions 1, 2, 3, 4, 7, 8, 9, 10, 11, 15, 16, 20. Extrinsic calculated from MSQ questions 5, 6, 12, 13, 14, 19. Overall satisfactions calculated from MSQ questions 1, 2, 3, 4, 5, 6, 7, 8, 9, 10, 11, 12, 13, 14, 15, 16, 17, 18, 19, 20.

A cross-tabulation analysis was conducted to assess a relationship between intrinsic job satisfaction, extrinsic job satisfaction, and the two variables of generational cohorts and tenure status. The cross-tabulation analysis did not reveal any relationship between intrinsic job satisfaction and generational cohorts (value $=3.162 ; \mathrm{p}>.05$ ), and extrinsic job satisfaction and generational cohorts (value $=6.280 ; \mathrm{p}>.05$ ). In addition, a Pearson Chi-Square analysis did not reveal any relationship between intrinsic job satisfaction and tenure status (value $=.805 ; \mathrm{p}>.05$ ), and extrinsic job satisfaction and tenure status (value $=3.945 ; \mathrm{p}>.05$ ).

Pearson Chi-Square analyses were conducted to assess a relationship between generational cohorts and each of the 20-items on the MSQ Short-Form, and tenure status and 
each of the 20-items on the MSQ Short-Form. Although the analysis did not reveal any significant relationships, results did show some chi-squares approaching significance. With a larger sample, these might have reached significance. These correlations included the variable generational cohorts and the extrinsic question "The way organizational policies are put into practice" $($ value $=13.933 ; \mathrm{p}=.084)$. Also the variable tenure status and the intrinsic question "The chance to be 'somebody' in the community" (value $=7.359 ; \mathrm{p}=.061$ ), and the intrinsic question "The chance to tell people what to do" (value $=6.370 ; \mathrm{p}=.095)$ were approaching significance.

\section{Research Question Five: Correlations between General Job Satisfaction and Intrinsic/Extrinsic Factors}

A Pearson Chi-Square analysis was conducted to assess a correlation between intrinsic and general satisfaction, and extrinsic and general satisfaction constructed from the MSQ ShortForm questions. Both intrinsic (value $=36.848)$ and extrinsic (value $=54.777)$ motivator variables are correlated with general satisfaction. In examining the responses, it was determined that respondents who were generally satisfied were more satisfied with intrinsic variables than with extrinsic variables. For example, as shown in Table 23, a 100 percent of respondents who were very satisfied overall, were also very satisfied on intrinsic variables. In contrast, as shown in Table 24, 92.9 percent of respondents who were very satisfied overall were only satisfied with extrinsic variables. In addition, 85.7 percent of those who were neutral overall were satisfied on the intrinsic variables and 71.4 percent of those who were neutral overall dissatisfied with extrinsic variables. 
Table 23

Correlation between Intrinsic Satisfaction and General Satisfaction

\begin{tabular}{|c|c|c|c|c|c|c|}
\hline \multirow{8}{*}{ Intrinsic } & & & General & atisfactio & & \\
\hline & & $\begin{array}{c}\text { Very } \\
\text { Dissatisfied }\end{array}$ & Dissatisfied & $\underline{\text { Neutral }}$ & $\underline{\text { Satisfied }}$ & $\begin{array}{c}\text { Very } \\
\text { Satisfied } \\
\end{array}$ \\
\hline & $\begin{array}{l}\text { very } \\
\text { Dissatisfied }\end{array}$ & $0.0 \%$ & $0.0 \%$ & $0.0 \%$ & $0.0 \%$ & $0.0 \%$ \\
\hline & Dissatisfied & $0.0 \%$ & $0.0 \%$ & $0.0 \%$ & $0.0 \%$ & $0.0 \%$ \\
\hline & Neutral & $0.0 \%$ & $0.0 \%$ & $14.3 \%$ & $0.0 \%$ & $0.0 \%$ \\
\hline & $\underline{\text { Satisfied }}$ & $0.0 \%$ & $0.0 \%$ & $85.7 \%$ & $69.0 \%$ & $0.0 \%$ \\
\hline & $\begin{array}{l}\text { Very } \\
\text { Satisfied } \\
\end{array}$ & $0.0 \%$ & $0.0 \%$ & $0.0 \%$ & $31.0 \%$ & $100.0 \%$ \\
\hline & Total & $0.0 \%$ & $0.0 \%$ & $100.0 \%$ & $100.0 \%$ & $100.0 \%$ \\
\hline
\end{tabular}

Pearson Chi-Square value $=36.848 ; \underline{p}<.05$ 
Table 24

Correlation between Extrinsic Satisfaction and General Satisfaction

\begin{tabular}{|c|c|c|c|c|c|c|}
\hline \multirow{8}{*}{ Extrinsic } & & & General & atisfaction & & \\
\hline & & $\begin{array}{c}\text { Very } \\
\text { Dissatisfied } \\
\end{array}$ & Dissatisfied & $\underline{\text { Neutral }}$ & $\underline{\text { Satisfied }}$ & $\begin{array}{c}\text { Very } \\
\text { Satisfied }\end{array}$ \\
\hline & $\begin{array}{l}\text { Very } \\
\text { Dissatisfied }\end{array}$ & $0.0 \%$ & $0.0 \%$ & $14.3 \%$ & $0.0 \%$ & $0.0 \%$ \\
\hline & Dissatisfied & $0.0 \%$ & $0.0 \%$ & $71.4 \%$ & $12.0 \%$ & $0.0 \%$ \\
\hline & $\underline{\text { Neutral }}$ & $0.0 \%$ & $0.0 \%$ & $14.3 \%$ & $55.2 \%$ & $0.0 \%$ \\
\hline & $\underline{\text { Satisfied }}$ & $0.0 \%$ & $0.0 \%$ & $0.0 \%$ & $32.8 \%$ & $92.9 \%$ \\
\hline & $\begin{array}{l}\text { Very } \\
\text { Satisfied } \\
\end{array}$ & $0.0 \%$ & $0.0 \%$ & $0.0 \%$ & $0.0 \%$ & $7.1 \%$ \\
\hline & Total & $0.0 \%$ & $0.0 \%$ & $100.0 \%$ & $100.0 \%$ & $100.0 \%$ \\
\hline
\end{tabular}

Pearson Chi-Square value $=54.777 ; \mathfrak{p}<.05$

\section{Research Question Six: Differences between Generational Cohorts and Tenure Status}

An analysis was completed of the online questionnaire open-ended questions conducted with county Extension faculty related to the Herzberg Motivation-Hygiene Theory, and the independent variables of generational cohort and tenure status. This includes the job satisfaction motivator factors-achievement, the work itself, responsibility, recognition, and advancementand the job satisfaction hygiene factors-supervision, salary, policy and administration, interpersonal relationships, and working conditions. Results of this analysis were then compared to analysis of the interviews conducted with supervisors of county Extension faculty. 


\section{Motivator (intrinsic) factors.}

Achievement. Established sub-codes under the intrinsic job satisfaction motivator achievement included: 1) successful program outcomes, defined as having successful programming with referenced outcomes such as knowledge gains, behavior changes, and/or positive teaching evaluations; 2) making a difference, defined as a personal sense of making a difference or having impact on others; 3) feeling of accomplishment, defined as feeling good about one's work; 4) feedback, defined as receiving positive informal feedback on one's work; and 5) annual review, defined as receiving positive results during the formal annual faculty review process.

Generational cohort. A cross-tabulation analysis was conducted of the MSQ Short-Form item number 20 "The feeling of accomplishment I get from the job" to assess a relationship between achievement and generational cohort. The Pearson Chi-Square did not reveal any significant relationship between achievement and generational cohort (value $=7.435 ; \underline{p}>.05)$.

Receiving feedback on one's work through clientele, peers, or a supervisor was a dominant theme in the qualitative data for both Baby Boomers and Generation X. Both groups cited receiving feedback through a variety of avenues including program evaluations or one-onone interactions from supervisors, clientele, colleagues, and community partners. For example, two Baby Boomers responded:

"Clientele feed-back. Their success is my success!"

"Development of a good reputation/image for local programs with the community." A Generation X respondent stated:

"Within Extension you may make a difference or impact someone's life but you won't know it for years. To me the recognition I get from the county residents means more than an award on state/national levels. When the participants of past programs talk about events/programs that were provided $4-5$ years...that is impact..." 
Successful programs and outcomes was the most central theme for both Millennials and Generation X. When asked how they knew they had achieved something through their work, these two groups most often cited successful programs with observed participant changes related to learning, behavior changes, and/or positive program evaluations. Comments from both groups focused on both short-term outcomes related to immediate learning in the classroom, and to long-term outcomes related to skills and behavior changes learned by participants through workshops and classes.

Millennials stated:

"When I see someone using the education/skills they received through my programming, [I] know that the program was a success."

"Impact. Are the people that I am working with reaping the benefit of me helping them? Did they see an increase crop yield? Did they see more tourism? Things like this give [me] intrinsic satisfaction."

Generation-X responded:

"When I see the results from my work; when I see that someone understands a new concept while I am teaching or when someone tells me that they tried something I told them about and it worked."

"It is rewarding to see these individuals implementing new behavior discussed in class."

As shown in Figure 2, an additional generational cohort difference in relation to

achievement included annual review. While some Generation-X and Baby Boomers cited results of their annual promotion and tenure review as an indicator of achievement, Millennials did not have any responses under this code. 


\section{Figure 2}

Achievement Visual Summary

\begin{tabular}{|c|c|c|c|c|c|c|}
\hline & & \multicolumn{3}{|c|}{ Generational Cohort } & \multicolumn{2}{|c|}{ Tenure Status } \\
\hline $\begin{array}{l}\text { Herzberg } \\
\text { Factor }\end{array}$ & $\begin{array}{l}\text { Perspective } \\
\text { of: }\end{array}$ & Millennials & $\begin{array}{c}\text { Generation } \\
\mathbf{X}\end{array}$ & $\begin{array}{c}\text { Baby } \\
\text { Boomers }\end{array}$ & $\begin{array}{c}\text { Non- } \\
\text { Tenured }\end{array}$ & Tenured \\
\hline \multirow[t]{3}{*}{ Achievement } & \multirow{2}{*}{$\begin{array}{l}\text { County } \\
\text { Extension } \\
\text { Faculty }\end{array}$} & & \multicolumn{2}{|c|}{$\begin{array}{l}\text { Feedback from clientele, } \\
\text { peers, or supervisor }\end{array}$} & \multirow{2}{*}{\multicolumn{2}{|c|}{$\begin{array}{l}\text { No identified } \\
\text { differences }\end{array}$}} \\
\hline & & \multicolumn{2}{|c|}{$\begin{array}{l}\text { Successful programs and } \\
\text { outcomes }\end{array}$} & & & \\
\hline & Supervisors & \multicolumn{2}{|c|}{$\begin{array}{l}\text { More likely to } \\
\text { acknowledge personal } \\
\text { achievements }\end{array}$} & $\begin{array}{l}\text { Less likely to } \\
\text { acknowledge } \\
\text { personal } \\
\text { achievements }\end{array}$ & \multicolumn{2}{|c|}{$\begin{array}{l}\text { No identified } \\
\text { differences }\end{array}$} \\
\hline
\end{tabular}

A few supervisors indicated there were some differences in the way generations

acknowledged their achievements. Some supervisors indicated that the younger two generations

more often acknowledged their achievements than Baby Boomers:

"I would say that some of our younger faculty (Millennials and Gen X) think that some of their achievements are a much bigger deal than our older faculty (Baby Boomers) think of the same achievements at this point in time or at the time they might have been achieving some of the milestones that our younger faculty are [at their age]."

"At every level they (Millennials) may recognize their achievement, they may reach smaller milestones in order to get to a big goal and they may recognize those smaller achievements. While Baby Boomers and perhaps Gen X may just see their eye on the prize, would recognize their achievement when they've met that goal, the big goal, and not recognize the small achievements. Whereas Millennials are more apt to recognize those small baby steps"

Tenure status. A cross-tabulation analysis was conducted of the MSQ Short-Form item number 20 "The feeling of accomplishment I get from the job" to assess a relationship between achievement and tenure status. The Pearson Chi-Square did not reveal any significant relationship between achievement and tenure status (value $=3.234 ; \mathrm{p}>.05$ ). 
In regards to tenure status, there were minimal differences in responses to achievement by those with tenure versus those without tenure. The majority of responses for both groups were coded under successful programs and outcomes and feedback. However, there were no distinctions between the tenure and non-tenure status of faculty on this issue.

Two supervisors stated there was no difference in the way the tenured and non-tenured county Extension faculty acknowledged their achievements. However, the remaining two supervisors discussed the importance of completing work that will gain county faculty merits in their faculty file and the importance of being able to write the achievements so they are clearly demonstrated in the faculty file.

"I think that both groups value achievement. There's a little bit of an attitude among the non-tenured of what I have to do for my file versus just what I need to do because it's important to do. So maybe to some extent they put a little more value on achievements that will be perceived by the reviewers as important."

"Yes I think there are some differences between tenure and non-tenure because when you're not tenured you're always trying to figure how you're going to write this up or how this will look in your file and as you're less worried about how you're going to write it up when you're tenured and you're more focused on how that benefits the client."

Work itself. Established sub-codes for the job satisfaction motivator the work itself included: 1) administrative role, defined as any administrative, county program coordination, or budget responsibility; 2) community relationships, defined as any community involvement or connecting with those within the community; 3) community resource, defined as serving as a resource to the community; 4) research, defined as discovery of new knowledge; 5) service or outreach, defined as service to the organization, or fulfilling the land-grant outreach mission; and 5) teaching or educational programming, defined any type of teaching or education programming. 
Generational cohort. Figure 3 illustrates one distinct difference between generations in regards to the work itself was that Generation Xers and Baby Boomers identified many more additional administrative responsibilities than Millennials. When examining the work itself, no additional differences were identified between generations. County Extension faculty identified the majority of their work activities as teaching or educational programming. A variety of work efforts identified were related to programs under each of the four program units. In addition, respondents also identified general teaching responsibilities that meet the needs of clientele:

"Developing or adopting programs to meet those needs; be responsive"

"Providing up-to-date educational materials and non-traditional educational opportunities for clientele in the community"

"Provide education and training that help make a difference in people's lives. Help youth and volunteers understand and appreciate their own importance in the community"

\section{Figure 3}

\section{Work Itself Visual Summary}

\begin{tabular}{|l|l|l|l|l|l|l|}
\hline & & \multicolumn{2}{|c|}{ Generational Cohort } & \multicolumn{2}{c|}{ Tenure Status } \\
\hline $\begin{array}{l}\text { Ferzberg } \\
\text { Factor }\end{array}$ & $\begin{array}{l}\text { Perspective } \\
\text { of: }\end{array}$ & Millennials & $\begin{array}{l}\text { Generation } \\
\text { X }\end{array}$ & $\begin{array}{c}\text { Baby } \\
\text { Boomers }\end{array}$ & Non-Tenured & Tenured \\
\hline $\begin{array}{l}\text { Work } \\
\text { Itself }\end{array}$ & $\begin{array}{l}\text { County } \\
\text { Extension } \\
\text { Faculty }\end{array}$ & $\begin{array}{l}\text { Less } \\
\text { administrative } \\
\text { responsibilities }\end{array}$ & $\begin{array}{l}\text { More administrative } \\
\text { responsibilities }\end{array}$ & $\begin{array}{l}\text { Less } \\
\text { administrative } \\
\text { responsibilities }\end{array}$ & $\begin{array}{l}\text { More } \\
\text { administrative } \\
\text { responsibilities }\end{array}$ \\
\cline { 2 - 6 } & Supervisors & $\begin{array}{l}\text { Early adopters } \\
\text { of technology }\end{array}$ & $\begin{array}{l}\text { Comfortable with job } \\
\text { responsibilities, able to } \\
\text { multitask }\end{array}$ & $\begin{array}{l}\text { Higher stress } \\
\text { level }\end{array}$ & $\begin{array}{l}\text { Less stress } \\
\text { level }\end{array}$ \\
\hline
\end{tabular}

When supervisors were asked about differences they experienced between the generational cohorts in regards to the work itself, some stated they experienced no differences. However, two did mention some differences in regards to comfort level with technology and handling job responsibilities.

"I think the major difference that I see across the groups when it comes to the handling of the tasks is probably the tools would be one significant area. We have a number of folks 
in those older generations (Baby Boomers and Gen X) that have accepted and adopted technology tools. Our younger group (Millennials) is much faster to do so and much more likely to do so unprompted."

"I do have Baby Boomers and I think the day to day activities for the most part they do multitask and focus on a variety of issues and challenges or opportunities at the same time. Not maybe at the same time, but they are able to cope and they can multitask I think would be the best way to describe it. I think the Generation X, a lot along that same lines. I think that they've advanced in their careers and matured. They don't get as flustered when they've got a lot of issues coming at them. I would say that the Millennials because most of them are in early career they do have a hard time, they get anxious and stressed more easily than the other generations. I think some of that is generational, some is just the lack of experience.

Tenure status. Again, the only distinction in regards to the work itself in relation to tenure status is that those who had received tenure identified many more additional administrative responsibilities than those that had not received tenure.

When supervisors were asked about the differences they experienced in how Extension faculty handle the tasks of their job in relation to their tenure status, supervisors primarily addressed the stress level of each group. They stated that those who had not yet achieved tenure experienced a higher stress level compared to those who had achieved tenure.

"About half of my faculty is tenured, and the other half is not yet. So the untenured faculty do seem to have a little more stress related to their job. Are a little more concerned about whether they're doing what I want them to do. It's not that they work harder, but tune in more to what's going to play well for the reviewers. The people that review their files. The tenured faculty are a little more relaxed about that. They know they're doing a good job. They know they've met the standard and they seem to settle in and do their work and not fret about whether people are happy with their work or not."

"I think it is a lot less stressful for those that have already achieved tenure. They're not as stressed, they're able to kind of take a breath and not be solely focused on how this is going to affect my future. It becomes less about them and more about the people that they serve."

Responsibility. Determined sub-codes for the job satisfaction motivator responsibility

included: 1) acts quickly, defined as is uninhibited or acts quickly when given responsibility; 2) fulfill all responsibilities, defined as fulfill all responsibilities regardless of whether they are 
meaningful; 3) not meaningful or give full attention, defined as if responsibility not meaningful, do not give full attention; 4) overwhelmed by responsibility, defined as overwhelmed by responsibilities; 5) process and prioritize, defined as process and prioritize to complete responsibility; and 6) seek new responsibility or challenge, defined as take on new responsibility or challenge.

Generational cohort. A cross-tabulation analysis was conducted of the MSQ Short-Form item number 15 "The freedom to use my own judgment" to assess a relationship between responsibility and generational cohort. The Pearson Chi-Square did not reveal any significant relationship between responsibility and generational cohorts (value $=0.992 ; \underline{p}>.05)$.

County Extension faculty were asked whether or not they seek new responsibilities. Table 25 indicates the majority of respondents do seek new responsibilities, with Millennials most likely to seek new responsibilities of the three generational cohorts.

\section{Table 25}

Seek New Responsibilities by Generational Cohort

\begin{tabular}{lcccc}
\hline & $\underline{\text { Yes }}$ & $\begin{array}{c}\text { \% of } \\
\text { Subgroup }\end{array}$ & $\underline{\text { No }}$ & $\begin{array}{c}\text { \% of } \\
\text { Subgroup }\end{array}$ \\
Millennials & 18 & 90 & 2 & 10 \\
Generation-X & 24 & 75 & 8 & 25 \\
Baby Boomers & 19 & 76 & 6 & 24 \\
\hline
\end{tabular}

$n=77$

An assessment of child codes under the job satisfaction motivator achievement did not indicate any differences among generational cohorts. However, supervisors' responses indicated differences, although their responses were not consistent among generations. Some supervisors 
stated Millennials were more hesitant to take on new responsibilities, while others felt Baby

Boomers were more hesitant to take them on.

"I think probably our veteran faculty, our older folks, are more likely to be fine with it than our younger faculty who are often once they've kind of got their way mapped out they're a little bit leery about accepting additional responsibilities sometimes, or different responsibilities, but it kind of varies with their personalities."

"Baby Boomer generation is more willing to take on new tasks or one's that maybe they don't originally see that they planned to do in a given period, like a year. They are more willing to do it without reservation, without questioning it. And that actually may even be the case for the Gen X'ers."

"the Millennials are more apt to jump into new projects. I'm not saying new policies. I think they're more apt to jump into new projects and start, they can see the benefits, they will kind of wrap their arms around it and get all enthusiastic about a new project. And the Generation X, I would think that they're, they may have to take a little time to understand the benefits of a program, but they're not as hesitant as maybe those Baby Boomers."

Tenure status. A cross-tabulation analysis was conducted of the MSQ Short-Form item number 15 "The freedom to use my own judgment" to assess a relationship between responsibility and tenure status. The Pearson Chi-Square did not reveal any significant relationship between responsibility and tenure status (value $=0.000 ; p>.05$ ).

Overall there were no differences in responses from county Extension faculty in relation to job satisfaction motivator responsibility between the two groups, those that had achieved tenure and those that had not achieved tenure as shown in Table 26. 
Table 26

Seek New Responsibilities by Tenure Status

\begin{tabular}{|c|c|c|c|c|}
\hline & $\underline{\text { Yes }}$ & $\begin{array}{c}\% \text { of } \\
\text { Subgroup }\end{array}$ & $\underline{\text { No }}$ & $\begin{array}{c}\% \text { of } \\
\text { Subgroup }\end{array}$ \\
\hline Tenure & 35 & 81 & 8 & 19 \\
\hline Non-Tenure & 27 & 79 & 7 & 21 \\
\hline
\end{tabular}

$n=77$

The majority of both groups reported they accepted new responsibilities for a variety of reasons from looking for a challenge to better able to serve constituents.

Untenured faculty stated:

“...great to have new responsibilities and take on new challenges. It helps you to continue to grow and not become complacent."

"...looking for new opportunities to help the citizens in my county."

"Because the responsibilities I receive in this job are to serve my community, its important to me."

Tenured faculty stated:

"The challenge of trying something new to see if you can do it."

"like to work and achieve high quality programs that are needed in my county."

"It's what makes the job exciting, challenging and rewarding."

As illustrated in Figure 4, while the majority of county Extension faculty, whether or not they had achieved tenure, indicated they seek new responsibilities, supervisors did not agree with this assessment. Supervisors indicated county Extension faculty without tenure tend to be more hesitant to take on new responsibilities.

“...but I think those that don't yet have tenure are less [likely], they'll do it but there's more kickback, or resistance."

"The one difference I might see there would be that a tenured faculty is going to take on a 
new responsibility because they genuinely want to. An untenured faculty member might take it and be just as willing to do it, but in the back of their mind because this will help me to get tenure. Not because I want to do this."

\section{Figure 4}

\section{Responsibility Visual Summary}

\begin{tabular}{|l|l|l|l|l|l|l|}
\hline & & \multicolumn{2}{|c|}{ Generational Cohort } & \multicolumn{2}{c|}{ Tenure Status } \\
\hline $\begin{array}{l}\text { Herzberg } \\
\text { Factor }\end{array}$ & $\begin{array}{l}\text { Perspective } \\
\text { of: }\end{array}$ & Millennials & \multicolumn{1}{|c|}{$\begin{array}{l}\text { Generation } \\
\text { X }\end{array}$} & Baby Boomers & $\begin{array}{l}\text { Non- } \\
\text { Tenured }\end{array}$ & Tenured \\
\hline $\begin{array}{l}\text { Work } \\
\text { Itself }\end{array}$ & $\begin{array}{l}\text { County } \\
\text { Extension } \\
\text { Faculty }\end{array}$ & $\begin{array}{l}\text { Most likely to } \\
\text { seek new } \\
\text { responsibilities }\end{array}$ & \multicolumn{2}{|l|}{ No identified differences } & $\begin{array}{l}\text { No identified } \\
\text { differences }\end{array}$ \\
\cline { 2 - 7 } & Supervisors & $\begin{array}{l}\text { More likely to } \\
\text { take on } \\
\text { responsibilities }\end{array}$ & $\begin{array}{l}\text { Divided on } \\
\text { taking on } \\
\text { responsibility }\end{array}$ & $\begin{array}{l}\text { More likely to } \\
\text { take on } \\
\text { responsibilities }\end{array}$ & $\begin{array}{l}\text { Hesitant } \\
\text { to take } \\
\text { on new } \\
\text { responsi- } \\
\text { bilities }\end{array}$ & $\begin{array}{l}\text { Less } \\
\text { hesitant } \\
\text { new take on } \\
\text { responsi- } \\
\text { bilities }\end{array}$ \\
\hline
\end{tabular}

Supervisors also discussed the flexibility to choose or not choose responsibilities that tenure provides to county Extension faculty:

“... little bit more picky once they've achieved tenure they can say well "is this a good fit for me?" They can be more picky, they can be pickier."

"Where if you've already been tenured you have some freedom to take on new responsibilities, or identify a new area where you want to go to personally."

Recognition. Generated sub-codes for the intrinsic job satisfaction factor recognition were divided into two subgroups. The first subgroup was the amount of recognition including: 1) adequate, defined as receives adequate recognition for work responsibilities; 2) minimal, defined as minimal recognition received or minimal opportunity for recognition; 3) desire or seek, defined as desires or seeks recognition; and 4) not desire or expect, defined as does not desire or expect to get recognition for completing job responsibilities. The second subgroup was the types of recognition including: 1) awards, defined as receiving awards, plaques, or 
certificates; and 2) praise and appreciation, defined as receiving praise from client, peer, or supervisor.

Generational cohort. A cross-tabulation analysis was conducted of the MSQ Short-Form item number 19 "The praise I get for doing a good job” to assess a relationship between recognition and generational cohort. The Pearson Chi-Square did not reveal any significant relationship between recognition and generational cohorts (value $=4.088 ; \underline{p}>.05$ ).

Minimal differences were found between generational cohorts with regard to the motivator achievement. As shown in Table 27, the majority of respondents indicated the recognition they received for their work was adequate.

Table 27

Recognition Received Adequate for Work by Generational Cohort

\begin{tabular}{lcccc}
\hline & $\underline{\text { Yes }}$ & $\begin{array}{c}\text { \% of } \\
\text { Subgroup }\end{array}$ & $\underline{\text { No }}$ & $\begin{array}{c}\text { \% of } \\
\text { Subgroup }\end{array}$ \\
Millennials & 18 & 90 & 2 & 10 \\
Generation-X & 24 & 75 & 8 & 25 \\
Baby Boomers & 19 & 76 & 6 & 24 \\
\hline
\end{tabular}

$n=77$

While responses from county Extension faculty did not indicate any differences among generational cohorts, interviews with supervisors did reveal supervisors experienced differences among their employees with regard to recognition. Although there were some variances between supervisors' responses in regards to Generation X, supervisors agreed that Millennials desired more recognition than Baby Boomers. However, two supervisors stated Generation X were similar to Millennials in desiring recognition, while the other two supervisors stated that Generation X desired less recognition similar to Baby Boomers. 
"So my younger faculty members, Millennials and Gen X, seem to push for more recognition, more national recognition. So maybe they desire that type of recognition, the awards more."

“think our Millennials and our Gen X'ers are much more interested in recognition than our Baby Boomers. Although the Boomers like to be recognized too. It seems to be more of a real need for the younger ones."

"I do think that Millennials want to be recognized more than Gen X or Baby Boomers. I think that they crave that validation of their work."

"It seems to me there is more of an expectation of some kind of reward or recognition of their great work from the Millennial group more than. Again I think the Baby Boomers and X'ers are more modest in that and they also just think that their job so there's no real need to get some kind of recognition for it."

Tenure status. A cross-tabulation analysis was conducted of the MSQ Short-Form item number 19 "The praise I get for doing a good job" to assess a relationship between recognition and tenure status. The Pearson Chi-Square did not reveal any significant relationship between recognition and tenure status (value $=0.704 ; \mathrm{p}>.05)$.

With regards to achievement by tenure status, as shown in Table 28, the majority of respondents indicated the recognition they received for their work was adequate.

Table 28

Recognition Received Adequate for Work by Tenure Status

\begin{tabular}{lcccc}
\hline & Yes & $\begin{array}{c}\text { \% of } \\
\text { Subgroup }\end{array}$ & $\underline{\underline{N o}}$ & $\begin{array}{c}\text { \% of } \\
\text { Subgroup }\end{array}$ \\
Tenure & 35 & 81 & 8 & 19 \\
Non-Tenure & 27 & 79 & 7 & 21 \\
\hline$n=77$ & & & &
\end{tabular}

As shown in Figure 5, county Extension faculty who were tenured indicated less of a desire for recognition than those who had not received tenure. Tenured county Extension faculty stated: 
"[I] don't need formal recognition in order to know that I am doing a good job"

"I don't need much recognition. Formal recognition is not what motivates me."

"I don't do my job for recognition"

\section{Figure 5}

Recognition Visual Summary

\begin{tabular}{|l|l|l|l|l|l|l|}
\hline & & \multicolumn{2}{|c|}{ Generational Cohort } & \multicolumn{2}{c|}{ Tenure Status } \\
\hline $\begin{array}{l}\text { Herzberg } \\
\text { Factor }\end{array}$ & $\begin{array}{l}\text { Perspective } \\
\text { of: }\end{array}$ & Millennials & $\begin{array}{l}\text { Generation } \\
\text { X }\end{array}$ & $\begin{array}{c}\text { Baby } \\
\text { Boomers }\end{array}$ & $\begin{array}{l}\text { Non- } \\
\text { Tenured }\end{array}$ & Tenured \\
\hline Recognition & $\begin{array}{l}\text { County } \\
\text { Extension } \\
\text { Faculty }\end{array}$ & \multicolumn{2}{|l|}{ No identified differences } & $\begin{array}{l}\text { More } \\
\text { desire for } \\
\text { recognition }\end{array}$ & $\begin{array}{l}\text { Less desire } \\
\text { for } \\
\text { recognition }\end{array}$ \\
\cline { 2 - 3 } & Supsire more & $\begin{array}{l}\text { Decosided on } \\
\text { recognition } \\
\text { recognition } \\
\text { desires }\end{array}$ & $\begin{array}{l}\text { Desire less } \\
\text { recognition }\end{array}$ & $\begin{array}{l}\text { Desire } \\
\text { more } \\
\text { recognition }\end{array}$ & $\begin{array}{l}\text { Desire less } \\
\text { recognition }\end{array}$ \\
\hline
\end{tabular}

Supervisors also indicated that county Extension faculty who had not received tenure desired recognition more than those who were tenured. This is probably due to the desire to receive the recognition to assist with making their case for tenure during their critical year.

"The untenured are really looking for that national recognition awards through their professional organization. Because they feel, or they seem to think, that will help them as they go up for tenure."

"I think again for those that have not yet been tenured desire more recognition, but again I think it's because they're building their case in their file."

Advancement. Sub-codes generated under the intrinsic job satisfaction motivator advancement included: 1) demonstrate accomplishments, defined as provided an opportunity to demonstrate accomplishments; 2) job security, defined as job security with tenure; 3) limited opportunity to advance, defined as limited opportunity for further advancement; 4) opportunity to advance, defined as promotion and tenure system provides an opportunity to advance; 5) part of organization, defined as opportunity to be a part of a larger system like on-campus faculty; 6) 
process, defined as the process of promotion and tenure file, amount of time, or review process; 7) receive input on performance, defined as promotion and tenure provides an opportunity to receive feedback on work; and 8) provides salary increase, defined as promotion and tenure provides increased salary or pay raise.

Generational cohort. A cross-tabulation analysis was conducted of the MSQ Short-Form item number 14 "The chance for advancement on this job" to assess a relationship between advancement and generational cohort. The Pearson Chi-Square did not reveal any significant relationship between advancement and generational cohorts (value $=2.494 ; \underline{p}>.05)$.

Overwhelmingly, the tenure and promotion process was identified as a major element of the motivator factor 'Advancement' by all three generational cohorts. However, Figure 6 shows there were differences identified in the process between the cohorts. 


\section{Figure 6}

Advancement Visual Summary

\begin{tabular}{|c|c|c|c|c|c|c|}
\hline & & \multicolumn{3}{|c|}{ Generational Cohort } & \multicolumn{2}{|c|}{ Tenure Status } \\
\hline $\begin{array}{l}\text { Herzberg } \\
\text { Factor }\end{array}$ & $\begin{array}{l}\text { Perspective } \\
\text { of: }\end{array}$ & Millennials & $\begin{array}{c}\text { Generation } \\
\mathbf{X}\end{array}$ & $\begin{array}{c}\text { Baby } \\
\text { Boomers }\end{array}$ & $\begin{array}{c}\text { Non- } \\
\text { Tenured }\end{array}$ & Tenured \\
\hline \multirow[t]{3}{*}{ Advancement } & \multirow{2}{*}{$\begin{array}{l}\text { County } \\
\text { Extension } \\
\text { Faculty }\end{array}$} & \multirow{2}{*}{$\begin{array}{l}\text { A high } \\
\text { stakes annual } \\
\text { review } \\
\text { process }\end{array}$} & \multicolumn{2}{|c|}{$\begin{array}{l}\text { Annual review process- } \\
\text { time consuming }\end{array}$} & \multirow[b]{2}{*}{$\begin{array}{l}\text { Lack of } \\
\text { importance } \\
\text { placed on } \\
\text { receiving } \\
\text { peer } \\
\text { feedback in } \\
\text { annual } \\
\text { review and } \\
\text { opportunity } \\
\text { to be part } \\
\text { of large } \\
\text { university } \\
\text { system }\end{array}$} & \multirow[b]{2}{*}{$\begin{array}{l}\text { Importance } \\
\text { placed on } \\
\text { receiving } \\
\text { peer } \\
\text { feedback in } \\
\text { annual } \\
\text { review, } \\
\text { Annual } \\
\text { review } \\
\text { provides } \\
\text { opportunity } \\
\text { to be part } \\
\text { of larger } \\
\text { university } \\
\text { system }\end{array}$} \\
\hline & & & $\begin{array}{l}\text { Annual } \\
\text { review } \\
\text { process not } \\
\text { best } \\
\text { depiction of } \\
\text { work }\end{array}$ & $\begin{array}{l}\text { Annual } \\
\text { review } \\
\text { process- } \\
\text { time of } \\
\text { year }\end{array}$ & & \\
\hline & Supervisors & \multicolumn{3}{|c|}{ No identified differences } & $\begin{array}{l}\text { More } \\
\text { importance } \\
\text { because } \\
\text { not yet } \\
\text { achieved } \\
\text { tenure }\end{array}$ & $\begin{array}{l}\text { Less } \\
\text { importance } \\
\text { because } \\
\text { achieved } \\
\text { tenure }\end{array}$ \\
\hline
\end{tabular}

Millennials focused on the pressure placed on them by the promotion and tenure process.

This is likely due to the fact that the majority of Millennials have not yet received tenure.

"It's too much pressure"

"My job security is dependent on this process"

"As a newer faculty, the process is a bear"

"Feel like the reporting system could be more stream-lined and intuitive."

Generation X commented on concerns that the promotion and tenure annual review did not provide the best depiction of their work. They also had concerns about the amount of time required to complete the annual process. 
"[I have] concerns about the objectivity of the internal review. I am also not certain that producing a document once a year, provides a clear depiction of agent's hard work.

"[I] need to justify my existence. For 4-6 weeks at the end of each year, I get very little of any actual work done for my community, because I'm writing a thesis paper which crows about and glorifies how much I'm doing for my community. Not, in my opinion, the best use of my time."

"The amount of "busy work" to put a file together."

"[Promotion and tenure] consumes a great deal of time - especially in a year when one has to complete a cumulative file and an annual file. I always internally weigh the time spent on my file against the things I could have been doing to serve my community and clientele."

"The fact that is does not serve our actual jobs. It is a square peg in a round hole approach. We chose work, not because it is worthwhile, or because we can do a good job. We choose work because the P\&T system demands it."

Baby Boomers comments also focused on the amount of time required to complete the annual

process and time of year the review was completed.

"Paperwork at end of year....too close to holidays....wish we were required to report throughout the year to avoid a big task of the annual reporting."

"The time of year [December 15] that it is due."

"Time it takes to build the annual review file."

No additional differences were found between generational cohorts in child codes in the job satisfaction motivator factor advancement.

Supervisors were asked whether they found any differences among county Extension faculty on the importance they placed on advancement through the promotion and tenure system by generational cohort. Overall supervisors did not experience based on generational cohort.

"I don't see a lot of importance placed on that for a lot of people, and I'm not sure why. I place more importance on it than they do for themselves."

"I would say it's an equal importance. I don't think they all equally understand it, or understand how best to complete it or how to adequately report their work but I think they all see it as important." 
"So that's the one where I don't see a lot of difference when people are in those systems and are after the next promotion, the next step or tenure. I really see that pretty even across the board. Everybody's pretty engaged in that and pretty intense about it."

Tenure status. A cross-tabulation analysis was conducted of the MSQ Short-Form item number 14 "The chance for advancement on this job" to assess a relationship between advancement and tenure status. The Pearson Chi-Square did not reveal any significant relationship between advancement and tenure status (value $=1.808 ; \underline{p}>.05)$.

There was a difference between those who had received tenure and those who had not under the child code "receive input on performance." Respondents who had received tenure placed a value on receiving peer feedback, however those who had yet received tenure did not mention "receive input on performance" by peers.

Comments from tenured faculty in the "receive input on performance" category included:

"Peers are the ones that decide whether you get a promotion or not."

"Annual review provide me feedback on ways to improve my work and reporting. And complimentary feedback from my peers on my work."

There was also a difference between those who had received tenure and those who had not under the child code "part of organization," defined as opportunity to be a part of a larger system like on-campus faculty. Overwhelmingly tenured county Extension faculty recognized the importance of participating in the promotion and tenure system because it provided an opportunity to be a part of the larger university system at the same level as on-campus faculty. Again, this was not mentioned by those who had not received tenure.

"Identification as a university faculty member in the trenches"

"[I] appreciate that the University grants us (Extension agents) the same respect and consideration as on campus faculty. I love being a faculty member of WVU, and without submitting to the P \& T system we wouldn't have that." 
Supervisors identified there were differences among county Extension faculty on the importance they placed on advancement through the promotion and tenure system by tenure status. Not surprisingly, those not having yet achieved tenure place more importance on the promotion and tenure process.

"The untenured are very anxious to get that first promotion and to get tenure."

"I think there's a difference in those working towards tenure. The untenured place more importance on it just because where they are in their career."

\section{Hygiene (extrinsic) factors.}

Supervision. Established sub-codes generated under the intrinsic job satisfaction motivator supervision included: 1) desired supervision, defined as requested or desired interaction/contact with supervisor; 2) self-directed, defined as prefer self-directed work or limited contact with supervisor; 3) not satisfied, defined as not satisfied with supervision received; and 4) satisfied, defined as satisfied with supervision received.

Generational cohort. A cross-tabulation analysis was conducted of the MSQ Short-Form item number 5 "The way my supervisor handles his/her employees" to assess a relationship between supervision and generational cohort. The Pearson Chi-Square did not reveal any significant relationship between supervision and generational cohort (value $=8.133 ; \underline{p}>.05)$.

As shown in Table 29, the majority of respondents indicated the supervision they received was adequate regardless of generational cohort. 


\section{Table 29}

\section{Supervision Received Adequate by Generational Cohort}

\begin{tabular}{lcccc}
\hline & $\underline{Y}$ & $\begin{array}{c}\% \text { of } \\
\text { Subgroup }\end{array}$ & $\underline{\underline{N o}}$ & $\begin{array}{c}\% \text { of } \\
\text { Subgroup }\end{array}$ \\
Millennials & 14 & 70 & 6 & 30 \\
Generation-X & 24 & 75 & 8 & 25 \\
Baby Boomers & 21 & 84 & 4 & 16 \\
\hline
\end{tabular}

$n=77$

The majority of respondents from all generations focused on their ability to be selfdirected in their work. The remoteness of county Extension offices results in limited direct supervision. County Extension faculty were positive about the opportunity to work independently.

Examples of statements from respondents included:

"Give me a job to do and get out of my way. Trust. Make me part of a valued team effort."

"[A] hands-off approach, be available when I need help but otherwise leave me to do my job"

"[I] prefer to work independently with limited supervision as appropriate for accountability."

"Tell me what you need done and get out of the way."

A difference in generational cohorts in the hygiene factor supervision was found under the child code "desired supervision." While responses from Generation X and Baby Boomers focused on the importance of availability of supervisors when assistance is needed, Millennials comments had a different tone focusing on their need for consistent interaction and feedback from their supervisor.

Comments from Baby Boomers and Generation Xers included: 
"supervisor who is available when needed"

"The person is there when I need them"

"support when I ask for it."

In contrast Millennials stated:

"need some form of monthly accountability."

"I would like for a supervisor to check in on a regular basis to know what is going on in my community and give me advice on how to better serve."

"work best when given periodic feedback. If something needs to be corrected or changed it is better to know sooner rather than later, and it is good to know if I am on the right track as well."

While supervisors were in agreement that Baby Boomers required the least amount of supervision and Millennials required additional supervision, there was conflicting opinions on Generation X. Some supervisors stated that Generation X required more supervision and some supervisors stated that Generation X required less supervision.

"So I always have a few faculty members, and they happen to be Gen X'ers, that need some very intense supervision. Performance management issues. But for the vast majority of my faculty members across the generational ranges they really need leadership and not supervision. My supervision is just a matter of sharing a vision and putting the resources in their hands to get to that vision."

"I have Millennials and Gen X'ers who want tons of feedback on their performance."

"I think for Baby Boomers less supervision is more. And for Millennials, I think they are more, they're in closer contact with their supervisor and they I think would like more contact if possible."

"the Millennials want more direction, but it makes sense to me. I would say all of these generations if they were starting out and they were green or they were new they're going to want more direction to understand where to go. The Baby Boomer and Gen X'ers require much less, they want more autonomy, want to be trusted to get the work done on their own."

Tenure status. A cross-tabulation analysis was conducted of the MSQ Short-Form item number five "The way my supervisor handles his/her employees" to assess a relationship 
between supervision and tenure status. The Pearson Chi-Square did not reveal any significant relationship between supervision and tenure status (value $=2.417 ; \underline{p}>.05$ ).

As shown in Table 30 when asked whether supervision received was adequate respondents who had achieved tenure agreed at a higher percentage than those who had yet to achieve tenure.

Table 30

Supervision Received Adequate by Tenure Status

\begin{tabular}{lcccc}
\hline & $\underline{\text { Yes }}$ & $\begin{array}{c}\text { \% of } \\
\underline{\text { Subgroup }}\end{array}$ & $\underline{\text { No }}$ & $\begin{array}{c}\text { \% of } \\
\text { Subgroup }\end{array}$ \\
Tenure & 36 & 84 & 7 & 16 \\
Non-Tenure & 22 & 65 & 12 & 35 \\
\hline$n=77$ & & & &
\end{tabular}

As seen previously from Millennials, those who had not achieved tenure focused their comments on increased desired interaction and communication from their supervisor.

Figure 7 shows that supervisors were in agreement that those who had not received tenure status required more supervision than those who had achieved tenure.

'I think that there's definitely more questions, I'm not sure if it's supervision or it's guidance related to how to document their work. I definitely get more seasonal related assistance around P\&T time from those that have not been tenured than from those that are."

"The untenured again are a little more high maintenance, have a few more questions about whether their doing the right thing or questions about does this count towards promotion and tenure or is this valuable to the file reviewers. So a little more supervision for the untenured."

"If you are untenured I think you do seek out more advice from supervisor." 


\section{Figure 7}

Supervision Visual Summary

\begin{tabular}{|c|c|c|c|c|c|c|}
\hline & & \multicolumn{3}{|c|}{ Generational Cohort } & \multicolumn{2}{|c|}{ Tenure Status } \\
\hline $\begin{array}{l}\text { Herzberg } \\
\text { Factor }\end{array}$ & $\begin{array}{l}\text { Perspective } \\
\text { of: }\end{array}$ & Millennials & $\begin{array}{c}\text { Generation } \\
\text { X }\end{array}$ & $\begin{array}{c}\text { Baby } \\
\text { Boomers }\end{array}$ & $\begin{array}{c}\text { Non- } \\
\text { Tenured }\end{array}$ & Tenured \\
\hline Supervision & $\begin{array}{l}\text { County } \\
\text { Extension } \\
\text { Faculty }\end{array}$ & $\begin{array}{l}\text { Desire for } \\
\text { consistent } \\
\text { feedback/inter- } \\
\text { action with } \\
\text { supervisor }\end{array}$ & \multicolumn{2}{|c|}{$\begin{array}{l}\text { Important for supervisor to } \\
\text { be available when needed }\end{array}$} & $\begin{array}{l}\text { Desire } \\
\text { increased } \\
\text { interaction } \\
\text { and } \\
\text { commun- } \\
\text { ication } \\
\text { from } \\
\text { supervisor }\end{array}$ & $\begin{array}{l}\text { Supervision } \\
\text { received } \\
\text { adequate }\end{array}$ \\
\hline & Supervisors & $\begin{array}{l}\text { Require more } \\
\text { supervision }\end{array}$ & $\begin{array}{l}\text { Divided } \\
\text { perspective } \\
\text { on amount of } \\
\text { supervision } \\
\text { required }\end{array}$ & $\begin{array}{l}\text { Require } \\
\text { minimum } \\
\text { supervision }\end{array}$ & $\begin{array}{l}\text { Require } \\
\text { more } \\
\text { supervision }\end{array}$ & $\begin{array}{l}\text { Require less } \\
\text { supervision }\end{array}$ \\
\hline
\end{tabular}

Salary. Sub-codes for the job satisfaction hygiene factor salary included: 1) important, defined as salary is important to job satisfaction; 2) not important, defined as salary is not important to job satisfaction; 3) long hours, defined as not compensated for long hours worked for job; 4) make a difference, defined as making a difference more important than higher salary; 5) not satisfied, defined as not satisfied with salary; and 6) satisfied, defined as satisfied with salary.

Generational cohort. A cross-tabulation analysis was conducted of the MSQ Short-Form item number 13 "My pay and the amount of work I do" to assess a relationship between salary and generational cohort. The Pearson Chi-Square did not reveal any significant relationship between salary and generational cohort (value $=8.892 ; \mathrm{p}>.05)$.

There were differences among generational cohorts in opinions on whether their salary is adequate. As shown in Table 31, in proportion to the number of respondents in each generation, 
Millennials were most likely to respond that their salary was adequate, followed by Baby

Boomers. Generation X'ers were the least likely of the three generational cohorts to respond that their salary was adequate.

Table 31

Salary Adequate by Generational Cohort

\begin{tabular}{lcccc}
\hline & $\underline{\text { Yes }}$ & $\begin{array}{c}\text { \% of } \\
\text { Subgroup }\end{array}$ & $\underline{\text { No }}$ & $\begin{array}{c}\text { \% of } \\
\text { Subgroup }\end{array}$ \\
Millennials & 14 & 70 & 6 & 30 \\
Generation-X & 12 & 38 & 20 & 62 \\
Baby Boomers & 11 & 46 & 13 & 54 \\
\hline
\end{tabular}

$n=76$

As the generational cohort least likely to agree that their salary was adequate, Generation X'ers were most likely to have their comments focused in the areas of "important," "long hours," and "not satisfied."

"I think it is very important"

"At times, the pay doesn't come close to the time and effort expended."

"It is the factor most likely to lead to my leaving extension."

"The pay rate is not keeping up with cost of living."

Some supervisors stated that in their experience Generation X'ers place the most importance on salary, which is consistent with the open-ended question results.

"I would say that is a much bigger deal with the Gen X'ers than anybody else and if I was going to rank it I'd say Gen X'ers really care about the salary first and foremost, Millennials come in next and our Baby Boomers come in third. That's just the people who I hear complain about salaries. I'm much more likely to hear somebody in that Gen $\mathrm{X}$ range be really unhappy about salary. In fact we've lost a number of them over salary. Even though they knew what our salaries were, they just couldn't live with them after they got in." 
"I think we all feel that we're underpaid and overworked. I probably get more bellyaching about salary from Gen X'ers."

While one supervisor provided insight into why the Millenial cohort is the most satisfied

with the salary received:

"I think that most people in Extension are not in it to get rich definitely. I find that question interesting because I've heard some new, young Millennials tell me they've worked, they've built their college career and any other work they could, post college, to be a county agent or to go into this line of work. So I don't think that there's a difference across age groups on the importance. And I think the importance is that their doing it because they love this kind of work or they want to make a difference, and it's not really about the money. Thank goodness."

Tenure status. A cross-tabulation analysis was conducted of the MSQ Short-Form item number 13 "My pay and the amount of work I do" to assess a relationship between salary and tenure status. The Pearson Chi-Square did not reveal any significant relationship between salary and tenure status (value $=2.103 ; \mathrm{p}>.05)$.

Table 32 shows when asked whether salary was adequate, respondents were split evenly regardless of whether or not the county Extension faculty member had or had not achieved tenure status.

Table 32

Salary Adequate by Tenure Status

\begin{tabular}{lcccc}
\hline & $\underline{\text { Yes }}$ & $\begin{array}{c}\text { \% of } \\
\text { Subgroup }\end{array}$ & $\underline{\text { No }}$ & $\begin{array}{c}\text { \% of } \\
\text { Subgroup }\end{array}$ \\
Tenure & 21 & 50 & 21 & 50 \\
Non-Tenure & 17 & 50 & 17 & 50 \\
\hline
\end{tabular}

$n=76$

Regardless of tenure status, many county Extension faculty referred to the number hours they expended on the job. 
"I work twice the amount of hours I get paid for."

"the number of hours that I put in weekly and on weekends wouldn't equate to minimum wage."

"At times, the pay doesn't come close to the time and effort expended."

Figure 8 illustrates that supervisors did not note any differences in county Extension faculty on the importance they placed on salary based on tenure status.

\section{Figure 8}

Salary Visual Summary

\begin{tabular}{|c|c|c|c|c|c|c|}
\hline & & \multicolumn{3}{|c|}{ Generational Cohort } & \multicolumn{2}{|c|}{ Tenure Status } \\
\hline $\begin{array}{l}\text { Herzberg } \\
\text { Factor }\end{array}$ & $\begin{array}{l}\text { Perspective } \\
\text { of: }\end{array}$ & Millennials & $\begin{array}{c}\text { Generation } \\
\text { X }\end{array}$ & $\begin{array}{c}\text { Baby } \\
\text { Boomers }\end{array}$ & $\begin{array}{c}\text { Non- } \\
\text { Tenured }\end{array}$ & Tenured \\
\hline \multirow[t]{2}{*}{ Salary } & $\begin{array}{l}\text { County } \\
\text { Extension } \\
\text { Faculty }\end{array}$ & $\begin{array}{l}\text { Salary } \\
\text { adequate }\end{array}$ & $\begin{array}{l}\text { Salary } \\
\text { inadequate }\end{array}$ & $\begin{array}{l}\text { Divided on } \\
\text { adequacy of } \\
\text { salary }\end{array}$ & \multicolumn{2}{|c|}{$\begin{array}{l}\text { No identified } \\
\text { differences }\end{array}$} \\
\hline & Supervisors & No discussion & $\begin{array}{l}\text { Salary } \\
\text { inadequate }\end{array}$ & No discussion & \multicolumn{2}{|c|}{$\begin{array}{l}\text { No identified } \\
\text { differences }\end{array}$} \\
\hline
\end{tabular}

Policy and Administration. County Extension faculty were asked what they liked least and best about the federal, state, and local partnership system of the Extension Service. Subcodes established for the policy and administration included: 1) disconnected, defined as a disconnection between levels; 2) interconnected, defined as levels are interconnected; 3) lack of program security, defined as a lack of stability or funding for program efforts; 4) program security, defined as provides stability and dependability for program efforts; 5) most out of resources, defined as provides opportunity to make the most out of resources at all levels; and 6) bureaucratic structure, defined as too many levels between where work gets done.

Generational cohort. A cross-tabulation analysis was conducted of the MSQ Short-Form item number 12 "The way organizational policies are put into practice" to assess a relationship 
between policies and administration and generational cohort. The Pearson Chi-Square did approach a significance relationship (value $=13.933 ; \mathrm{p}=.084)$.

Figure 9 shows there were no identified differences between generational cohorts in the area of policy and administration as a job satisfaction hygiene factor based on a review of qualitative data. County Extension faculty were asked to identify what they liked least and most about the structure of the federal, state, and local partnership system of the Extension Service. The majority of comments acknowledged the tri-partnership provided an opportunity for all level descriptions, including federal, state and local to be interconnected, as well as a disconnection between levels.

Comments about the interconnection between levels included:

"That we're all interconnected. It's nice being part of something much bigger than just what we are locally."

"Information is shared from the USDA all the way down to the local county level"

"Partnerships and collaborations make programming possible that would not otherwise be possible."

Comments about disconnections between levels included:

"Lack of understanding between partners. Differing missions at different levels."

"Sometimes there is duplication of effort - as if the right hand isn't aware of what the left is doing." 


\section{Figure 9}

Policy and Administration Visual Summary

\begin{tabular}{|c|c|c|c|c|c|c|}
\hline & & \multicolumn{3}{|c|}{ Generational Cohort } & \multicolumn{2}{|c|}{ Tenure Status } \\
\hline $\begin{array}{l}\text { Herzberg } \\
\text { Factor }\end{array}$ & $\begin{array}{l}\text { Perspective } \\
\text { of: }\end{array}$ & Millennials & $\begin{array}{c}\text { Generation } \\
\text { X }\end{array}$ & $\begin{array}{c}\text { Baby } \\
\text { Boomers }\end{array}$ & $\begin{array}{c}\text { Non- } \\
\text { Tenured }\end{array}$ & Tenured \\
\hline $\begin{array}{l}\text { Policy and } \\
\text { Administration }\end{array}$ & $\begin{array}{l}\text { County } \\
\text { Extension } \\
\text { Faculty }\end{array}$ & \multicolumn{3}{|c|}{ No identified differences } & $\begin{array}{l}\text { Partnerships } \\
\text { as source of } \\
\text { security }\end{array}$ & $\begin{array}{l}\text { Concerned } \\
\text { about } \\
\text { program } \\
\text { security }\end{array}$ \\
\hline & Supervisors & \multicolumn{3}{|l|}{ No discussion } & \multicolumn{2}{|l|}{ No discussion } \\
\hline
\end{tabular}

Supervisors did not identify any differences in how county Extension faculty regard policy and administration of the Extension structure of federal, state, and local partnerships based on generational cohort.

Tenure status. A cross-tabulation analysis was conducted of the MSQ Short-Form item number 12 "The way organizational policies are put into practice" to assess a relationship between policies and administration and tenure status. The Pearson Chi-Square did not reveal any significant relationship between policies and administration and tenure status (value $=6.407$; p>.05).

Those with tenure identified lack of program security less than those without tenure.

Comments from county Extension faculty that had achieved tenure:

"We're very dependent on grant funding. When the economy is good, it's great. When times are tough like now, it's difficult."

"always get weary of budget cuts."

"The lack of stability."

In contrast, those had not achieved tenure were also aware of the security provided through the federal, state, and local partnership.

"acts as a funding safety net - when some sources of funding aren't available, the whole system doesn't collapse." 
"In some ways it helps with job security, because the money isn't coming from one source."

"when one partner is struggling, often another area can pick up the slack."

Supervisors also did not identify any differences based on tenure status in how county Extension faculty regard policy and administration of the Extension structure of federal, state, and local partnerships.

Interpersonal relationships. The job satisfaction hygiene factor interpersonal relationships includes three major categories: interpersonal relations with a superior, interpersonal relations with peer, and interpersonal relations with client.

Interpersonal relationships with supervisor. Sub-codes established for interpersonal relationship with supervisor included: 1) limited, defined as limited interaction or supervision from supervisor; 2) positive, defined as positive, supportive relationship with supervisor; 3) method, defined as types of methods of interaction. Interactions defined by county Extension faculty focused on limited and positive, while supervisor interviews also revealed the category of method, focusing on how the county Extension faculty member interacted with the supervisor.

Generational Cohort. While some county Extension faculty in each generational cohort stated they had minimal or no interaction with their supervisor, overall each generation identified a positive interaction with their supervisor. Responses addressed opinions about their relationship, the type of support received, and general opinion of their supervisor.

Millennials stated:

"[I] feel comfortable being open and honest with my supervisor."

"I have a good working relationship with her, and feel that I can contact her if need be." Generation X stated: 
"I feel she is someone I can call any time and she will help me to the best of her ability. I may not always like the answer, but she always give me good reason."

"She is always open minded and listens to you. She is motivational and gives us encouragement to try new things, do things differently. She is on our side and supports us."

\section{Baby Boomers stated:}

"She builds leadership."

"As I have told her directly in the past I think she is firm, but fair."

Supervisors were asked to describe the differences they experienced in how Extension

faculty from the four generational cohorts interact with them. While one supervisor stated

Generations X'ers seek her out when they have questions or want direction, others stated

Millennials required or requested more interaction than other generational cohorts.

"I see for the most part my Gen X'ers seem to need a little more hand holding than either the Baby Boomers or the Millennials. I'm not sure why that is.... They come to me more with questions and for direction."

"I think their need for approval, I hate to do it, but I break the Millennials out again differently....I do think there's a difference between the Millennials and everybody else. They're way more apt to tell you of all their successes, all along the way. Every little thing they do they promote it to you. Where I find the Gen X'ers and the Baby Boomers kind of let the work speak for itself."

One supervisor acknowledged that while Millennials request more interaction, they also

acknowledge the supervisor's authority more than Baby Boomers.

"I think the view of my authority for Millennials is more acknowledged than I think probably the Baby Boomers....I think the Baby Boomers just do their job and they acknowledge me, or contact me only when they have to. You know when it becomes an absolute they have to get some information from Morgantown, or they have to tell on themselves that they've done something. Whereas the Millennials probably contact me more and see me as an authority figure more so than those people with more experience, more than those people that are more mature in their careers. The Gen X'ers I think, I'm trying to think, they contact me a good bit I but I think the Millennials probably contact me the most followed by the Gen X'ers and then the Baby Boomers." 
Another supervisor discussed the methods which the county Extension faculty utilized to interact, stating that Millennials were more apt to use technology and expected a faster communication response time than Baby Boomers.

"I get a lot of texts. I get a lot of social media driven stuff. I even have people interact with me on Facebook. The Baby Boomers do not do that. The other thing is I get a lot of real time because our Millennial group in particular is pretty hooked to their cell phones. I might get a text in the middle of a meeting and they want pretty immediate feedback. Whereas our Baby Boomers know you might leave a message, you might send an email, it might take a couple of days. There's a different expectation with how they interact."

This same supervisor also shared that the younger generations are more willing to share personal information with her.

"Like there are things I know about our younger faculty that I would never have shared with a supervisor when I was their age. Things that are not my business to know. Things I wouldn't even have wanted my supervisor to know. It's just kind of all out there."

Tenure status. Within the sub-code labeled positive, as illustrated in Figure 10, there was a difference between the way those with tenure and those who had yet to achieve tenure described their relationship with their supervisor. County Extension faculty who had achieved tenure status focused their responses on the types of support and response received from the supervisor. Examples include:

"She is someone I can call any time and she will help me to the best of her ability. I may not always like the answer, but she always give me good reason."

"My supervisor is responsive, supportive and have open communication. I can trust her with delicate information."

"I respect and admire my current supervisor. She has helped in difficult situations and the situation was resolved." 


\section{Figure 10}

Interpersonal Relationships with Supervisor Visual Summary

\begin{tabular}{|c|c|c|c|c|c|c|}
\hline & & \multicolumn{3}{|c|}{ Generational Cohort } & \multicolumn{2}{|c|}{ Tenure Status } \\
\hline $\begin{array}{l}\text { Herzberg } \\
\text { Factor }\end{array}$ & $\begin{array}{l}\text { Perspective } \\
\text { of: }\end{array}$ & Millennials & $\begin{array}{c}\text { Generation } \\
\text { X }\end{array}$ & $\begin{array}{c}\text { Baby } \\
\text { Boomers }\end{array}$ & $\begin{array}{c}\text { Non- } \\
\text { Tenured }\end{array}$ & Tenured \\
\hline $\begin{array}{l}\text { Interpersonal } \\
\text { Relationship } \\
\text { with } \\
\text { Supervisor }\end{array}$ & $\begin{array}{l}\text { County } \\
\text { Extension } \\
\text { Faculty }\end{array}$ & \multicolumn{3}{|c|}{ No identified differences } & $\begin{array}{l}\text { Focused on } \\
\text { actual } \\
\text { relationship } \\
\text { with } \\
\text { supervisor }\end{array}$ & $\begin{array}{l}\text { Focused on } \\
\text { types of } \\
\text { support and } \\
\text { responses } \\
\text { received } \\
\text { from } \\
\text { supervisor }\end{array}$ \\
\hline & Supervisors & $\begin{array}{l}\text { Require or } \\
\text { request more } \\
\text { interaction, } \\
\text { more likely } \\
\text { to } \\
\text { acknowledge } \\
\text { supervisor's } \\
\text { authority, } \\
\text { early } \\
\text { adopters of } \\
\text { technology } \\
\text { and therefore } \\
\text { expect fast } \\
\text { communicati } \\
\text { on response }\end{array}$ & $\begin{array}{l}\text { Request less } \\
\text { interaction }\end{array}$ & $\begin{array}{l}\text { Request } \\
\text { less } \\
\text { interact- } \\
\text { tion, Do } \\
\text { not expect } \\
\text { fast } \\
\text { communi- } \\
\text { cation }\end{array}$ & $\begin{array}{l}\text { Require } \\
\text { more } \\
\text { interaction }\end{array}$ & $\begin{array}{l}\text { Require } \\
\text { less } \\
\text { interaction }\end{array}$ \\
\hline
\end{tabular}

In contrast, county Extension faculty who had not yet received tenure focused their comments on the actual relationship between them and the supervisor. Those who had yet to achieve tenure stated:

"I feel comfortable being open and honest with my supervisor."

She is very attentive to my requests and values me as an asset. It is nice to be able to talk to your supervisor about work or about anything else and have an understanding ear and no judgment."

"I have a good working relationship with her, and feel that I can contact her if need be."

Supervisors were asked to describe the differences they experienced in how Extension faculty with tenure versus without tenure interact with them. While one supervisor stated there 
was no difference in interaction based on tenure status, the remaining supervisors believed more interaction was required with those who had not achieved tenure.

"A little more faculty initiated interactions with the untenured."

"Untenured is definitely likely to interact more."

"I definitely get more interactions from the folks that have not yet been tenured. More questions or more needs for assistance and supervision, as compared to the tenured folk."

Interpersonal relationships with peer. Established child codes for interpersonal relationship with peer included: 1) competition, defined as competition among peers; 2) friendship, defined as developed friendship with peer; 3) mentor, defined as serves as mentor to peer; 4) partnership, defined as established partnership with peers working on projects or work. Interactions identified by county Extension faculty with peers focused on friendship, mentor, and partnership, while a supervisor interview also revealed the category of competition.

Generational Cohort. While Generation X'ers and Baby Boomers defined their interpersonal relationships with peers in relation to the sub-codes friendship, mentor, and partnership, Millennials primarily identified with the sub-code partnership. For the sub-code friendship Generation X'ers and Baby Boomers stated:

"We have friendships as well as excellent working relationships. It is a privilege to work with these folks."

"I have numerous extension professionals that I consider not only co-workers but friends. They have helped me with difficult work situations as well as personal situations."

"Friends. These are the only people that know the frustrations/blessings of this profession."

For the sub-code mentor Generation X'ers and Baby Boomers stated:

"We have a pretty close need regional group of Extension faculty who get together several times a year to plan programs together and to support each other."

"I work closely with another agent from a neighboring county. We bounce ideas off of 
each other and ask each other questions/advice.”

"I have a mentoring relationship with many of the younger agents in our state."

"I have a close relationship with some faculty members that I pursue for advice and how to better do my job."

Millennials primarily described their interpersonal relationships with peers as a

partnership, stating:

"I work closely with another agent in another county. We started our jobs around the same time, and it's been nice to have someone to write lessons with, co-teach and work on making ourselves more successful in the job."

"Partnership with a fellow agent in a neighboring county. We have co-hosted master gardener courses. We also co-chair a statewide committee for the WV Food and Farm Coalition concerning school gardens and youth agriculture."

"I have recently had the opportunity to start working a lot with a colleague on teaching and writing opportunities. It is always a great option to have someone to work with on a project."

Supervisors were asked about the differences they have witnessed in how county

Extension faculty interacted with their peers based on generational cohort. While two of the supervisors stated they did not experience any differences between interactions with peers, the remaining two supervisors did identify differences in interactions with peers. One supervisor shared that Generation X'ers created more interactions with their fellow generation, stating:

"The Gen X'ers seem to initiate more of those interactions with peers. They're very supportive of each other. Very close good friends, and work together really well. More so than the Baby Boomers or the Millennials."

In contrast, another supervisor identified she had experienced the younger generations

generated more competition amongst themselves and peers, stating:

"I see more competition with the younger sets (Millennials and Gen X) than I do with our Baby Boomers. It could be because they're much more settled in their career. Maybe they were competitive when they were young and I wasn't around to observe that. At this stage there is a lot more competition, and sometimes that competition crosses the line to be uncomfortable. I have had to mediate a number of disputes between our younger 
faculty that basically had to do with competition. The other thing I observe sometimes are our younger faculty not doing well in interactions with our older faculty, maybe kind of being not as open to them but be real open to other young faculty and myself."

Tenure Status. Regardless of tenure status there were no differences identified in the subcodes of partnership or mentor. As also illustrated in Figure 11, the only difference identified in the job satisfaction hygiene factor interpersonal relationships was those with tenure were more likely to characterize their relationship as a friendship than those without tenure. Examples from comments from those with tenure under the sub-code friendship included:

"My peers are my salvation. It is wonderful to have co-workers that are friends who you can talk with and vent to!"

"We have a unique opportunity to get to know one another and to share a bond of friendship and comradery."

\section{Figure 11}

Interpersonal Relationships with Peer Visual Summary

\begin{tabular}{|l|l|l|l|l|l|l|}
\hline & & \multicolumn{2}{|c|}{ Generational Cohort } & \multicolumn{2}{c|}{ Tenure Status } \\
\hline $\begin{array}{l}\text { Herzberg } \\
\text { Factor }\end{array}$ & $\begin{array}{l}\text { Perspective } \\
\text { of: }\end{array}$ & Millennials & $\begin{array}{l}\text { Generation } \\
\text { Xaby }\end{array}$ & $\begin{array}{l}\text { Non- } \\
\text { Boomers } \\
\text { Tenured }\end{array}$ & \multicolumn{1}{c|}{ Tenured } \\
\hline $\begin{array}{l}\text { Interpersonal } \\
\text { Relationship } \\
\text { with Peer }\end{array}$ & $\begin{array}{l}\text { County } \\
\text { Extension } \\
\text { Faculty }\end{array}$ & $\begin{array}{l}\text { Focused on } \\
\text { partnerships }\end{array}$ & $\begin{array}{l}\text { Focused on friendships } \\
\text { and mentorships }\end{array}$ & $\begin{array}{l}\text { Focused on } \\
\text { partnerships }\end{array}$ & $\begin{array}{l}\text { Focused on } \\
\text { friendships } \\
\text { and } \\
\text { mentorships }\end{array}$ \\
\cline { 2 - 7 } & Supervisors & $\begin{array}{l}\text { Create more } \\
\text { competition }\end{array}$ & $\begin{array}{l}\text { Create more } \\
\text { interactions } \\
\text { with peers }\end{array}$ & $\begin{array}{l}\text { No } \\
\text { discussion }\end{array}$ & $\begin{array}{l}\text { More } \\
\text { interactions } \\
\text { providing } \\
\text { support } \\
\text { among } \\
\text { peers }\end{array}$ & $\begin{array}{l}\text { No } \\
\text { discussion }\end{array}$ \\
\hline
\end{tabular}

The majority of supervisors did not identify a difference in interpersonal relationships among peers based on tenure status. One supervisor stated:

"I don't see a difference there. I think the county agents are a pretty tight community and I don't feel that that piece of it plays much of a part in their interaction."

However, one supervisor did provide: 
"I see more faculty initiated interactions with untenured. I believe that's providing support for each other."

Interpersonal relationships with client. Child codes for interpersonal relationships with client included: 1) beneficial, defined as relationships that are beneficial; 2) difficult, defined as difficulty interacting with clients; 3) friendship, defined as developed friendship with client; 4) method, defined as types of methods of interaction; and 5) partnership, defined as forming partnerships with clients. County Extension faculty described interpersonal relationships with clients under the sub-codes of beneficial, friendship, and partnership, and supervisor interviews added the categories of difficulty and method.

Generational Cohort. As seen in Figure 12, comparisons of interpersonal relationships by peers in relation to generational cohort did not reveal any significant differences. However, supervisor interviews did reveal different types of interpersonal relationships and interactions between generational cohorts with clients.

“The Baby Boomers in particular are way more relaxed and comfortable and don't feel inferior to their clients or folks that are the gatekeepers in the community. It just comes out of being inexperienced I think, and young. I think that the difference I see. Millennials and even on the low end of the Gen X scale have some discomfort. I don't know if the right word's inferior, but they're just not comfortable around the community leaders. Maybe a little nervous."

"We have some of our younger faculty, Millennials and Gen X, that have a tough time understanding that it is very, very important, those impressions that we make. And that the perceptions of people are more important than what we think we're doing, because perception is reality. Some of our younger people have had a really tough time understanding that in a job where elected officials weigh in on your performance, and our clientele can be very, very mixed in their every way, their education level, their socioeconomic levels, their backgrounds. That we have to figure out that middle place to communicate effectively with everybody across diverse channels." 


\section{Figure 12}

Interpersonal Relationships with Client Visual Summary

\begin{tabular}{|c|c|c|c|c|c|c|}
\hline & & \multicolumn{3}{|c|}{ Generational Cohort } & \multicolumn{2}{|c|}{ Tenure Status } \\
\hline $\begin{array}{l}\text { Herzberg } \\
\text { Factor }\end{array}$ & $\begin{array}{l}\text { Perspective } \\
\text { of: }\end{array}$ & Millennials & $\begin{array}{c}\text { Generation } \\
\text { X }\end{array}$ & $\begin{array}{c}\text { Baby } \\
\text { Boomers }\end{array}$ & $\begin{array}{c}\text { Non- } \\
\text { Tenured }\end{array}$ & Tenured \\
\hline \multirow[t]{2}{*}{$\begin{array}{l}\text { Interpersonal } \\
\text { Relationship } \\
\text { with Client }\end{array}$} & $\begin{array}{l}\text { County } \\
\text { Extension } \\
\text { Faculty }\end{array}$ & \multicolumn{3}{|c|}{ No identified differences } & \multicolumn{2}{|c|}{$\begin{array}{l}\text { No identified } \\
\text { differences }\end{array}$} \\
\hline & Supervisors & \multicolumn{2}{|c|}{$\begin{array}{l}\text { Discomfort or difficulty } \\
\text { working with clients }\end{array}$} & $\begin{array}{l}\text { More } \\
\text { comfortable } \\
\text { working with } \\
\text { clients }\end{array}$ & \multicolumn{2}{|c|}{$\begin{array}{l}\text { Conflicting responses } \\
\text { whether tenured or } \\
\text { non-tenured more } \\
\text { likely to have } \\
\text { interactions with new } \\
\text { clients }\end{array}$} \\
\hline
\end{tabular}

Tenure Status. No differences among county Extension faculty were found in interpersonal relationships with clients based on tenure status. However, Figure 12 illustrates that conflicting information was received from supervisors. One supervisor stated untenured faculty were more likely to work with new clientele.

"I don't think there's much of a difference, although probably untenured faculty members are more likely to reach out to new clientele than tenured faculty members in some cases, but other than that no difference in term of reaching out to clientele."

In contrast, another supervisor said tenured faculty members are more likely to have increased interactions with clients.

"Well they've [tenured county Extension faculty] had more experience doing it so they have more interactions with clients. They've identified more groups to work with and that may be just a function of time in that role. That they have stronger and higher quantity of interactions with clients."

Work conditions. Sub-codes established for the job satisfaction hygiene factor work conditions included: 1) flexibility, defined as flexibility of work and schedule, and ability to design own plan of work; 2) hours, defined amount of hours worked or required to complete job;

3) lack of funding, defined as lack of funding for office and/or programming; 4) office 
atmosphere, defined as atmosphere of working environment; 5) physical workspace, defined as the physical workspace itself; 6) politics, defined as politics of work; 7) interactions, defined as interactions with persons/organizations experienced through work; and 8) variety of work, defined as variety of change of work.

Generational cohort. A cross-tabulation analysis was conducted of the MSQ Short-Form item number 17 "The working conditions" to assess a relationship between working conditions and generational cohort. The Pearson Chi-Square did not reveal any significant relationship between working conditions and generational cohort (value $=5.881 ; \underline{p}>.05)$.

As illustrated in Figure 13, no differences were established on work conditions by generational cohort. While minimal comments were provided on the lack of funding, politics, and hours worked, it was overwhelmingly clear that flexibility of the job was a positive work condition factor identified by all generations.

"[I] like being able to set my own schedule (most of the time anyway) and decide how I want to utilize my time among a variety of programs/ initiatives."

"Being able to set my own hours and job responsibilities"

"I like the freedom I have to go do visits when I need to and to develop programs to teach and share needed information."

"[A] flexibility to create your own responsibilities. It is nice to be able to use your interests and strengths to do good for the community." 


\section{Figure 13}

Work Conditions Visual Summary

\begin{tabular}{|c|c|c|c|c|c|c|}
\hline & & \multicolumn{3}{|c|}{ Generational Cohort } & \multicolumn{2}{|c|}{ Tenure Status } \\
\hline $\begin{array}{l}\text { Herzberg } \\
\text { Factor }\end{array}$ & $\begin{array}{l}\text { Perspective } \\
\text { of: }\end{array}$ & Millennials & $\begin{array}{c}\text { Generation } \\
\mathbf{X}\end{array}$ & $\begin{array}{c}\text { Baby } \\
\text { Boomers }\end{array}$ & $\begin{array}{c}\text { Non- } \\
\text { Tenured }\end{array}$ & Tenured \\
\hline \multirow[t]{2}{*}{$\begin{array}{l}\text { Work } \\
\text { Conditions }\end{array}$} & $\begin{array}{l}\text { County } \\
\text { Extension } \\
\text { Faculty }\end{array}$ & \multicolumn{3}{|c|}{ No identified differences } & \multicolumn{2}{|c|}{$\begin{array}{l}\text { No identified } \\
\text { differences }\end{array}$} \\
\hline & Supervisors & $\begin{array}{l}\text { More likely to } \\
\text { voice } \\
\text { dissatisfaction } \\
\text { and focus on } \\
\text { tangible } \\
\text { working } \\
\text { conditions }\end{array}$ & \multicolumn{2}{|c|}{$\begin{array}{l}\text { Less likely to voice } \\
\text { dissatisfaction on working } \\
\text { conditions }\end{array}$} & \multicolumn{2}{|c|}{ No discussion } \\
\hline
\end{tabular}

Supervisors were asked to describe any differences they experienced between

generational cohorts in how county Extension faculty regarded their work conditions. While two supervisors stated they did not experience any differences by generational cohort, two supervisors shared that in their experience Millennials were more unsatisfied with their working conditions than Generation X'ers or Baby Boomers.

"I hear a lot more about that from the Millennials. I hate to throw them under the bus. I feel sometimes it's a good trait on their part because they are vocal about what they expect out of a good workplace. I don't think I was doing that when I was their age, but I see the difference in the Millennial group."

"In general I find our newer faculty, our younger faculty, that things like the conditions of their offices, and things like that matter more to them than to our older faculty. We have a lot of people that have worked for years in less than ideal office settings, with less than ideal office furniture. I certainly get a lot more requests from our younger faculty for upgrades in those kind of things. Also, in some cases, a desire to get perks that generally come with seniority faster than previous groups might have gotten it, like parking for example."

Tenure status. A cross-tabulation analysis was conducted of the MSQ Short-Form item number 17 "The working conditions" to assess a relationship between working conditions and 
tenure status. The Pearson Chi-Square did not reveal any significant relationship between working conditions and tenure status (value $=2.903 ; \mathrm{p}>.05$ ).

Overall, no differences were identified based on tenure status in the job satisfaction hygiene factor work conditions. It was apparent, regardless of tenure status, that in addition to flexibility, county Extension faculty enjoy the variety of work their job provides.

"No two days are ever the same. It is the challenge that keeps me getting out of bed each day anxious to get started with my work."

"[I] love that you never know what you are going to have to do with each passing day- it is always changing."

"I love that one day I go from talking about sheep to discussing a disease issue on tomatoes."

"[I] really like the changing work environment. One day I am in the office, the next in a pasture, the next at the capitol. This has been a very nice component of this job."

Supervisors also did not identify any differences based on tenure status in how county

Extension faculty regard their working conditions.

\section{Summary}

West Virginia University Extension Service county faculty are 43 percent male and 57 percent female. The majority are Generation X'ers (40.5\%), followed by Baby Boomers (31.6\%), and Millennials (25.3\%). County Extension faculty are most likely to have achieved tenure (54.4\%), and hold the academic rank of Extension assistant professor (32.9\%) or Extension associate professor (26.6\%). They are most likely to have their significant areas of contribution as teaching and service $(82.3 \%)$. The majority of county Extension faculty serve in the 4-H Youth Development unit (40.2), followed by the Agriculture and Natural Resources unit (32.7). They have served ten years or less (55.7\%), work 41 to 50 hours per week (64.5\%), are away from home an average of 15 to 31 nights per year (34.2\%), and supervise one or two employees (59.5). County Extension faculty are 'satisfied' in their job and are intrinsically 
motivated. No differences were found statistically between generational cohorts and faculty tenure status on job satisfaction, intrinsic job satisfaction, and extrinsic job satisfaction. However, there were qualitative differences among county Extension faculty on intrinsic and extrinsic job satisfaction based on generational cohort and tenure status. 


\section{Chapter Five}

\section{Summary, Conclusions, and Recommendations}

This chapter examines the results of the research study, which includes an evaluation of the work environment and job satisfaction of county Extension faculty members working for the West Virginia University Extension Service. This chapter provides a summary including the purpose of the study, research questions, and a review of the research methods. Next, conclusions are addressed by each research question, including findings related to existing scholarly literature. The chapter concludes with recommendations, including implications for practice and proposed future research.

\section{Summary}

Purpose of the study. The purpose of the study was to evaluate work environment and job satisfaction of county Extension faculty members in 55 West Virginia counties under the auspices of the West Virginia University Extension Service utilizing a work motivation construct, generational cohort framework, and faculty rank schema.

Research questions. The research questions for the study were:

1. What is the demographic profile (gender, generational cohort based on year of birth, tenure status, academic rank, area of significance [teaching and research or teaching and service], number of program areas served, and years of service) as a county Extension faculty member in West Virginia?

2. What is the work environment profile of county Extension faculty in West Virginia (average number of hours worked a week, number of overnights away from home per year, number of direct contacts, number of people supervised, and percent of time spent per year on teaching/research/service)? 
3. What is the overall job satisfaction among county based Extension faculty?

4. Are county Extension faculty more intrinsically motivated or extrinsically motivated?

5. Is there a correlation between the overall level of job satisfaction of county Extension faculty, and intrinsic and extrinsic work factors?

6. Are there differences between generational cohorts and faculty tenure and non-tenure status on overall job satisfaction, intrinsic job satisfaction, and extrinsic job satisfaction among county Extension faculty?

Research methods. The research study utilized a mixed-method research design with methodological triangulation. First, document review was conducted of employment trend data at the West Virginia University Extension service provided by the office of human resources. Second, an online questionnaire was implemented, which included the modified Minnesota Satisfaction Questionnaire (MSQ) Short-Form, open-ended questions on job satisfaction, and questions related to demographics and the respondent's workplace environment. Third, interviews were completed with supervisors of county Extension faculty for the four WVUES program unit areas. The interviews focused on the supervisors' perceptions and experiences supervising county Extension faculty.

The study used a descriptive correlational design that evaluated the differences of job satisfaction as measured by the MSQ Short-Form, including an analysis of intrinsic and extrinsic factors based on the Herzberg Motivation-Hygiene Theory. Results were then analyzed with independent variables.

\section{Conclusions}

Research question one. What is the demographic profile (gender, generational cohort based on year of birth, tenure status, academic rank, area of significance [teaching and research 
or teaching and service], number of program areas served, and years of service) as a county Extension faculty member in West Virginia?

Gender. Forty-three percent of West Virginia University Extension Service (WVUES) county faculty were male, while 57 percent were female. According to the National Center for Education Statistics (NCES) (2012) the majority of traditional faculty in degree-granting institutions were male (51.8\%), and 48.2 percent were female. Results of this study were not consistent with NCES data, with the percent of females outnumbering the percent of males.

Generational cohort. For this study Baby Boomers comprised almost 32 percent (31.6\%), 44.5 percent were Generation X'ers, and 25.3 percent were Millennials. No Pre-Baby Boomers participated in this study. According to a national survey of college and universities conducted through the Higher Education Research Institute (HERI) in 2010 to 2011, the largest group of undergraduate higher education faculty were Baby Boomers, born between 1945 and 1965 (60.6\%) (Hurtado, Eagan, Pryor, Whang, and Tran, 2012). A little more than a third were Generation X'ers (35.6\%), born between 1966 and 1980. Only 2.6 percent were Millennials, born in 1981 or later. Finally, a small group of faculty (1.5\%) were born in 1940 or earlier. Unlike traditional faculty described in the HERI study, the majority of Extension faculty in this study were younger than overall higher education+ faculty. This may be a result of higher turnover in Extension due to the stress and demands of the work.

Tenure status. A majority of WVUES county faculty had tenure with 54.4 percent tenured. The HERI study found 56.2 percent of full-time undergraduate faculty were tenured (Hurtado et al., 2012). A slightly higher percentage of faculty from that study were tenured than were WVUES county faculty (56.2\% versus $54.4 \%)$. Results of this study were consistent with HERI data, with similar percentages of faculty tenured. 
Academic rank. This study found that 59.9 percent of WVUES county faculty were at the rank of either Extension Assistant or Associate Professor, versus 39.2 percent at the rank of Extension Instructor. The HERI study found that 31.9 percent of full-time undergraduate faculty at public universities were at the rank of professor, the next largest rank was assistant professor at 24.9 percent and associate professor following closely behind at 24.5 percent (Hurtado et al., 2012). Unlike typical initial appointments at assistant professor in higher education institutions, the majority of county faculty for the WVUES were hired without a terminal degree in their field. The county Extension faculty were hired at the instructor level rather than at the assistant professor level, and therefore a greater representation at the lower ranks would be expected. While in the HERI study the largest portion of traditional faculty $(31.9 \%)$ were at the rank of professor, no WVUES county faculty were at that rank because a terminal degree was required to achieve the level of full professor.

Areas of significance. The majority of WVUES county faculty had teaching and service as their significant areas of contribution $(82.3 \%)$. In research universities, traditional faculty generally have research and teaching as their significant areas of contribution. The implication of a de-emphasis on research results in less peer reviewed publication and an increased focus on outreach to address needs within communities.

Program area served. In this study the majority of respondents, almost 42 percent (41.8\%), served in the 4-H Youth Development Unit (41.8\%). This was followed by Agricultural and Natural Resources (29.1\%), Families and Health (21.5\%), and Community and Economic Workforce Development (7.6\%). Comparable data for other Extensions systems is not available.

Years of service. Almost 33 percent (32.9\%) of county Extension faculty had served five years or less. The second largest group of WVUES county faculty (22.8\%) had worked for 
WVUES for six to 10 years, followed by those who had worked 11 to 20 years $(20.3 \%)$. As a result of WVUES having a large group of relatively inexperienced faculty, administrators and more experienced faculty may have to spend more time mentoring newer faculty on their responsibilities. Examples may include responsibilities related to their county work and promotion and tenure procedures.

Research question two. What is the work environment profile of county Extension faculty in West Virginia (average number of hours worked a week, number of overnights away from home per year, number of direct contacts, number of people supervised, and percent of time spent per year on teaching/research/service)?

Average number of hours worked a week. The work environment profile of WVUES county faculty was unique. A career in Extension involves a commitment of long and irregular hours, including working many nights and weekends (Place \& Jacob, 2001; Rousan \& Henderson, 1996; Strong \& Harder, 2009). Although the standard work week for full-time West Virginia University employees is 37.5 hours a week (West Virginia University Extension Service, n.d.), 64.5 percent of county Extension faculty in this study said they work an average of 41 to 50 hours per week. According to the MSQ question "The pay and the amount of work I do" 38.0 percent were either dissatisfied or very dissatisfied.

Number of overnights away from home. In addition, 34.2 percent of the county Extension faculty members in this study said they are away from home an average of 15 to 21 nights per year, and 22.8 percent are away from home an average of 22 to 28 nights per year. The majority of county Extension faculty are away four work weeks or more a year, which could create stress at home and at the workplace. 
Number of direct contacts. More than 35 percent (35.4\%) of WVUES county faculty made an average number of 999 or less contacts per year. This was followed by 1,000 to 1,999 $(22.8 \%)$ and 2,000 to $2,999(16.5 \%)$. It is difficult to compare this data with traditional faculty and the number of students they teach per year. Number of students taught vary greatly by institution size and discipline.

Number of people supervised. Almost 60 percent (59.5\%) of WVUES county faculty supervised one or two employees. However, 13.9 percent did not supervise anyone in their offices. Unless they are in an administrative role, traditional faculty rarely supervise employees except a limited number of graduate assistants.

Percent of time spent on teaching/research/service. In this study the average percent of time spent in each area, as reported by county Extension faculty was 47.2 percent on service, 37.7 percent on teaching, and 15.6 percent on research. Full-time undergraduate faculty at public universities that completed the HERI study reported an average of 5 to 8 hours teaching per week (40.6\%), an average of 5 to 8 hours preparing for teaching per week (25.1\%), one to four hours per week on research and scholarly writing (25.4\%), and 49.9 percent reported completing no community or public service on average per week (Hurtado et al., 2012). In addition, traditional faculty have numerous commitments including counseling and advising students, committee work and meetings, and other administrative duties. This is consistent with findings of June (2012), where the number of faculty in the tenure system have decreased and faculty teaching loads and committee work have increased.

Research question three. What is the overall job satisfaction among county based Extension faculty? 
More than 91 percent (91.1\%) of WVUES county faculty rated their job satisfaction as either satisfied or very satisfied. None of the respondents rated their job satisfaction as very dissatisfied or dissatisfied. The majority of respondents were satisfied (73.4\%), rather than very satisfied (17.7\%). This finding is similar to that of the HERI study that found more than 73 percent $(73.2 \%)$ of traditional faculty at public universities were satisfied or very satisfied with their job (Hurtado, 2012).

The two lowest rated job satisfaction categories of WVUES county faculty were for "My pay and the amount of work I do" (2.94) and "The way organizational policies are put into practice" (2.97). These categories represent hygiene factors, and can lead to job dissatisfaction. Job dissatisfaction could result in a variety of factors including low morale, decreased productivity, or job turnover. The starting salary of a county based Extension faculty member at WVUES at the level of Extension Instructor is $\$ 40,000$ to $\$ 43,000$ (J. Momen, personal communication, March 25, 2013). This is slightly lower in comparison to other Extension systems average entry level salary for county Extension faculty with masters' degree of $\$ 43,295$ (Land-Grant Impacts, 2013). This is also lower than the average nine month salary of $\$ 45,057$ for agriculture, agriculture operations, and related sciences faculty at four year colleges and universities for 2010 to 2011 (Chronicle of Higher Education, 2011). On the MSQ question "The way organizational policies are put into practice" a third of responses (32.9\%) were dissatisfied or very dissatisfied, and only $30.4 \%$ were satisfied or very satisfied. The largest group $(36.7 \%)$ were neutral on the way organizational policies were put into practice.

The two highest categories (tied) "The chance to do different things from time to time" (4.78) and "The chance to do things for other people" (4.78) represented intrinsic factors, and can lead to job satisfaction. Additional job satisfiers for county Extension faculty were working 
with people, flexibility, and variety of work activities. When descriptive variables were analyzed with a general job satisfaction variable containing all questions on the MSQ Short-Form, the "adequacy of supervision received" and "recognition of work" were also positively related to general job satisfaction.

The survey of literature revealed that very few, if any, studies had been completed on academic faculties' perception of supervision and relation to administrators. Del Favero (2003) notes a lack of knowledge around the relationship between faculty and administrators in colleges and universities, including their partnership through shared governance. A general observation in traditional faculty settings is that the chair is generally a peer amongst peers, who handles administrative duties but has little few direct supervisory responsibilities for faculty. In comparison, in the Extension Service system, there is more supervision from unit directors than from chairs in the traditional setting, although it is still limited. As cited by Amend (1970), county Extension faculty are often located many miles away from their institution and immediate supervisor resulting in limited direct supervision. Research findings showed this type of supervision is successful for county Extension faculty because it provides the right balance of structure and autonomy.

Recognition for traditional faculty occurs through a variety of ways including publication in books and peer reviewed journals, and professional conferences. Teaching awards are also a form of recognition to acknowledge pedagogic excellence (Brawer, Steinert, St-Cyr, Watters, \& Dauphinee, 2006). County Extension faculty in this study also acknowledged receiving recognition from a variety of sources including clients, peers, and supervisors. This recognition comes in the form of publications and awards, although there is a lower expectation that faculty produce peer-reviewed journal articles. However, county Extension faculty place the strongest 
emphasis on the importance of immediate feedback from those they work with locally.

Research question four. Are county Extension faculty more intrinsically motivated or extrinsically motivated?

West Virginia University Extension Service county faculty were both intrinsically and extrinsically motivated with regard to job satisfaction, as shown by the fact that most of the means on all the questions on the MSQ Short Form were over 3.00 on a 5-scale. However, WVUES county faculty were more motivated by intrinsic factors than extrinsic factors.

Intrinsic job satisfaction. The highest mean scores were on intrinsic factors and the lowest mean scores were on extrinsic factors. The findings in this study were consistent with other job satisfaction studies completed in other Extension service systems with field faculty, which demonstrated higher intrinsic than extrinsic job satisfaction means (Haas, 2002; Stumf, 2003; Elizer, 2010). In addition, all of the intrinsic factor means in this study scored above a 4.0 except for "The chance to tell people what to do" which had a mean of 3.58. In contrast none of the extrinsic factor means scored above a 4.0.

Intrinsic work factors that can contribute to internal growth and motivate the employee are: achievement, the work itself, responsibility, recognition, and advancement (Herzberg, 1966). WVUES county faculty enjoyed work that fits in with their values and gives them opportunities to select and direct their own activities. They like to keep busy, work alone on the job, do things differently from time to time, be "somebody" in the community, do things that go along with their conscience, appreciate steady employment, and do things for other people. Interestingly, the one question where the mean was under 4.0 was "the chance to tell people what to do." It may be that county Extension faculty are not as comfortable serving in supervisory roles. The HERI study $(n=3,501)$ found almost 62 percent $(61.5 \%)$ of traditional faculty at 
public universities also experience alignment between their work and personal values (Hurtado, et al., 2012). However, traditional faculty do not see community service as important to their job as county Extension faculty. Active participation in community action programs is less important $(28.0 \%)$ as is becoming a community leader (18.8\%). A study of agriculture science professors, a disciple that bares directly on the work of Extension, also found that academic faculty are motivated by intrinsic factors. The factor "work itself" was the most motivating aspect of their job, and the least motivating factor was the "work conditions." This is consistent with Castillo and Cano (2004), that found traditional faculty were most satisfied with content of their job and least satisfied with context of their job. County Extension faculty were more satisfied with the actual doing and tasks of their job than their work environment.

Extrinsic job dissatisfaction. The Herzberg Motivation-Hygiene Theory extrinsic factors that can result in job dissatisfaction include: supervision, salary, policy and administration, interpersonal relationships, and working conditions (Herzberg, 1966). WVUES county faculty were less enthusiastic about the competence of their supervisor, the way their supervisor handles his/her employees, the way organizational policies were put into practice, their pay, the amount of work they have to do, and the chances for advancement on the job. The means on these factors were between 2.94 and 3.91 .

The HERI study found traditional faculty at public universities place low importance of being well off financially (25.6\%), but experienced high stress over personal finances (65.5\%), and 47.0 percent were satisfied with their salary (Hurtado, et al., 2012). Traditional faculty had a low opinion of administrators considering faculty concerns when making policy (14.6\%) and faculty are typically at odds with campus administration (19.5\%) (Hurtado, et al., 2012). Traditional faculty experienced high stress from lack of personal time (81.5\%) and stress from 
colleagues (62.2\%) (Hurtado, et al., 2012).

Generational cohort/tenure status. In this study intrinsic and extrinsic factors were not impacted by generational cohort or tenure status. The cross-tabulation analyses did not reveal any significant relationships between either of these variables and intrinsic job satisfaction and extrinsic job satisfaction. As a result, there may be no need to make changes to organizational structure and policies based on generational cohort and tenure status in order to improve job satisfaction.

Research question five. Is there a correlation between the overall level of job satisfaction of county Extension faculty, and intrinsic and extrinsic work factors?

In this study both intrinsic and extrinsic motivators were correlated with general job satisfaction for WVUES county faculty. One hundred percent of respondents who were very satisfied with their general job satisfaction were also very satisfied with the intrinsic motivating factors. However, a lower percent of respondents who were very satisfied with general job satisfaction were very satisfied with extrinsic factors (92.9\%). The two factors with a significant correlation with general job satisfaction were supervision and recognition. As a result, these two factors should be given special consideration in professional development decisions.

In the interviews with WVUES unit directors, there was some acknowledgement that there was room for improvement within the organization in both intrinsic and extrinsic job satisfaction factors. This included increased recognition and salary enhancement. Other possible improvements supervisors could implement within the organization may include might be involving county Extension faculty in creating policy, create additional opportunities for advancement, and providing increased opportunity for involvement in governance. 
Research question six. Are there differences between generational cohorts and faculty tenure and non-tenure status on overall job satisfaction, intrinsic job satisfaction, and extrinsic job satisfaction among county Extension faculty?

The findings are based on the Herzberg Motivation-Hygiene Theory. The two-factor theory includes five motivator factors, or intrinsic factors, that contribute to internal growth and motivate the employee to superior performance and effort (Herzberg, 1966). These include: achievement, the work itself, responsibility, recognition, and advancement. Five hygiene, or extrinsic factors, are derived from the actual work environment, describing the relationship to the context or environment and can create job dissatisfaction (Herzberg, 1966). These include: supervision, salary, policy and administration, interpersonal relationships, and working conditions.

In this study, based on the MSQ Short-Form, generational cohort and tenure status were not found to be predictors of job satisfaction for WVUES county faculty. This compares favorably with other studies that did not find correlation of job satisfaction and generational cohorts (Cennamo and Gardner, 2008; Wong et. al., 2008). Parry and Urwin (2010) explain that some studies have been unable to find predicted differences in work values based on generation. They recommend further research to distinguish generational effects from age. This coincides with Rhodes (1983), who suggests that job satisfaction may be affected by other factors rather than age or generational cohort effects.

Qualitative differences between generational cohort and tenure status were found from answers to non-MSQ Short-Form questions on the online survey and by interviews of WVUES unit supervisors. 
Achievement. The statistical analysis did not find a significant correlation between a person's generational cohort and the Herzberg motivation factor of achievement. However, Baby Boomers tended to select very satisfied more often than Generation X'ers who selected very satisfied more often than Millennials.

An analysis of qualitative data indicated the two younger generations defined achievement as the success of their programs and achieving outcomes. For Generation Xers and Millennials the feedback needs to be directly linked to the success of their programs.

The two older generations defined achievement in terms of the type of feedback they received from clients, colleagues, and non-supervisory feedback from supervisors. This feedback could be both informal and formal (i.e. tenure and promotion review). Supervisors noticed the two younger generations were more apt to talk to them about their achievements than Baby Boomers.

The statistical analysis also did not show a significant correlation between a person's tenure status and the Herzberg motivation factor of achievement. There were also no differences between the tenure statuses in the qualitative data. Supervisors did acknowledge that they did experience some differences with non-tenured faculty more focused on accomplishing achievements and demonstrating the achievements in their faculty file.

Work itself. Generation X'ers and Baby Boomers, those who had achieved tenure, were more likely to identify administrative responsibilities in their work. This is likely due to the fact that WVUES county faculty who were Baby Boomers had been around longer and therefore assumed more of the administrative responsibilities versus those newer to the organization.

West Virginia University Extension unit supervisors identified Millennials were early adopters of technology, and were quicker to adapt to using these tools in their work. Whereas, older generations are slower to adopt technology. The need for immediate feedback, addressed 
in the extrinsic factor "supervision," are related to the Millennials use of technology and social media. Millennials are accustomed to experiencing immediate feedback through technology which is why they may expect this same immediate feedback from their supervisor.

Differences in the work itself by tenure status were generally attributed by WVUES unit supervisors to the stress of preparing for the promotion and tenure process. County Extension faculty in this study who had achieved the milestone of tenure were identified as being more relaxed. In comparison, those who had yet to achieve tenure experienced higher stress levels.

Responsibility. The statistical analysis did not find a significant correlation between a WVUES county faculty member's generational cohort and the Herzberg motivation factor of responsibility. However, Baby Boomers tended to select very satisfied more often than Generation X'ers who selected very satisfied more often than Millennials.

Based upon the assessment of qualitative data no differences on generational cohorts were found among WVUES county Extension faculty. Unit directors were mixed in their assessment. Some thought Millennials were more likely to take on new responsibilities, because they are enthusiastic about new job responsibilities. Others thought Baby Boomers were more likely to take on new responsibilities.

In regards to accepting new job responsibilities, WVUES unit supervisors stated that tenure gives the flexibility of choosing or not choosing responsibilities. This is consistent with Nir and Zilberstein-Levy (2006) findings of pre-tenure faculty to "play safe" and make conservative decisions when making professional considerations. Untenured faculty may sometimes take on new responsibilities because they believe refusing would jeopardize their relationship with their supervisor and be harmful to their progress towards promotion and tenure. 
Recognition. No generational differences were identified within the WVUES county faculty respondent data. However, unit supervisors noted younger generations, particularly Millennials, and those that had yet to receive tenure were more likely to seek recognition. This is due to their desire to build a strong case for promotion and tenure. This is consistent with the research that Millennials desire recognition (Crow and Stichnote, 2010; Marston, 2007). Henderson (1996) acknowledged faculty have left Extension due to a lack of recognition for work well done.

County Extension faculty who were tenured indicated less of a desire for recognition than those who had not received tenure. This was consistent with supervisors who also indicated that county Extension faculty who had not received tenure desired recognition more than those who were tenured. The desire of those without tenure to receive recognition is likely due to a belief that recognition will assist with making their case for tenure during their critical year.

Advancement. When asked about the promotion and tenure system, all generational cohorts addressed the actual process of the system. Millennials described promotion and tenure as a high stakes process that creates stress. Generation X'ers and Baby Boomers described the process as time consuming. Generation $X^{\prime}$ ers also felt the process did not provide an adequate depiction of their work. Baby Boomers were unhappy with the time of year the process occurred, which was mid-December during the holiday season.

West Virginia University county faculty that had achieved tenure acknowledged participating in the promotion and tenure system allowed them to participate at the same level as traditional faculty. County Extension faculty with tenure were more aware that participating in the tenure process allowed them the opportunity to be a part of a larger university system. 
Whereas, those who had yet to receive tenure were more focused on achieving tenure than the awareness of being at the same level as traditional faculty.

Supervision. While the two older generations preferred supervisors available only when needed, Millennials desired more consistent feedback or interaction with their supervisors. This is consistent with supervisor observations that Millennials require more supervision than other generations. Supervisors were mixed about Generation X. Baby Boomers were identified as requiring the least amount of supervision. This could be due to the fact that Baby Boomers are more experienced and knowledgeable about how to complete their job responsibilities.

West Virginia University Extension county faculty who had not achieved tenure desired increased interaction from their supervisor. In contrast, those that had achieved tenure required less supervision. Those with tenure have had more professional development, and more experience and job security in their position. In contrast those yet to receive tenure require more guidance and may not be as sure of themselves in their work.

Salary. Both the qualitative and quantitative data confirms that Generation X'ers are the least satisfied with their salaries. This is consistent with the findings of Twenge (2010) which found Generation X'ers were significantly more likely to value the extrinsic work factors of salary, status, and prestige. It could be projected that Millennials were satisfied with raises at the time of hiring and Baby Boomers have had years of salary increases, while Generation X'ers have primarily experienced years with no pay raises. Neither the qualitative or quantitative data shows adequacy of salary based on tenure status.

Policy and administration. Differences were revealed in the qualitative data among tenure statuses regarding their opinions of the federal, state, and local partnership. While tenured WVUES county faculty expressed concern about program security, those without tenure saw the 
partnerships as a source of security. The reason for this difference could be that those with tenure have more administrative responsibilities and are therefore aware of county budgets and the need for program continuation and funding. They are more conscious of the impact these cuts can have on their programming and success of their work. Millennials and those without tenure expect to change careers many times in their lifetime and are not as worried about diminished budget that affect programming. They know they can and probably will move on in their careers if programs are cut. Millennials are also newer to their jobs and are not as invested in the success of the organization as their more experienced peers.

Interpersonal relationships with supervisor/peers/clients. Overall relationships with supervisors were positive, but limited in interaction for all generational cohorts. Unit supervisors believe Millennials require and request more interaction than any other generation. There were differences between tenure statuses with those with tenure focusing on the types of support and responses received from the supervisor, while untenured WVUES county faculty focused on their actual relationship with the supervisor. This is likely due to the fact that untenured faculty need feedback from supervisors more than tenured faculty. Tenured faculty may be more secure and may be able to look at their supervisors more as peers or mentors.

Millennials described relationships with peers in terms of partnerships, while Generation X'ers and Baby Boomers describe relationships in terms of friendship and mentorship. The older generations have more personal relationships, while Millennials have more structured relationships. This finding on Baby Boomers is consistent with the study by Cennamo and Gardner (2008) that found Baby Boomers reported better "person-organization values" than Generation X and Millennials. 
In assessing interpersonal relationships with clients, supervisors noted Millennials and Generation X'ers had more discomfort or difficulty working with clients. In contrast, Baby Boomers were more comfortable working with clients. This is likely due to the greater work experience of Baby Boomers, and an increased ability to work more effectively with their clients.

Working conditions. There were no generational differences cited on work conditions. All generational cohorts addressed the flexibility of their work schedule and the control they have over the nature of their work. Supervisors cited that Millennials are more likely to voice dissatisfaction and focus on tangible working conditions. This is consistent with the research that Millennials are outspoken about their work environment with supervisors (Crow and Stichnote, 2010; Marston, 2007).

\section{Recommendations}

Recommendations for practice. Based upon the results of this dissertation research study, there are four major recommendations for practice. If executed these recommendations may improve the overall job satisfaction of county Extension faculty, and enhance the functioning of the West Virginia University Extension Service.

- West Virginia University Extension Service county faculty should be provided increased opportunities for extrinsic motivation.

Research results from this study indicated that West Virginia University county faculty were more intrinsically than extrinsically motivated. Examples include salary and incentive pay should be increased, policies could be created to strengthen and improve the lines of communication between supervisors and supervisees to assist with supervision. Examination of organizational policies could strengthen supervisor to peer, and peer to peer interpersonal relationships which could increase job satisfaction. 
- West Virginia University Extension Service county faculty should be provided increased opportunities for intrinsic motivation.

Although West Virginia University Extension county faculty were intrinsically motivated, the organization needs to be aware of how to continue intrinsic motivation for employees. As a result, increased opportunities for intrinsic motivation should be provided to WVUES county faculty. Examples could include providing increased responsibility through leadership positions or additional opportunities for recognition within the organization by peers and supervisors. Possible considerations in regards to advancement related to promotion and tenure policies and procedures should be reviewed. Other promotional levels and promotable steps within the current ranks may be considered, in addition to bringing in county Extension faculty at the assistant professor level.

- Supervision practices should be reviewed based on the age of county Extension faculty. Quantitative research results revealed a significant relationship between job satisfaction and the adequacy of supervision received, with those very satisfied with their job overall also satisfied with supervision. Qualitative research showed that younger faculty desire and require additional feedback from supervisors than more experienced county faculty. Policies should be reviewed to ensure that supervisors are accessible and meeting regularly with younger faculty to assist with job satisfaction.

- Recognition policies should be reviewed for county Extension faculty.

Research results revealed a significant relationship between job satisfaction and the recognition of work, with a majority of those very satisfied with their job revealing they received adequate recognition. Qualitative research findings found that both county Extension faculty and supervisors identified that those had not received tenure desired recognition more than those who 
had achieved tenure. Practices should be reviewed to ensure that there are both formal and informal methods to recognize employees by both peers and supervisors.

Recommendations for future research. Based upon the research results of this dissertation research study, there are six major recommendations for future research.

- Conduct an analysis of the supervisory skills and approaches of Extension supervisors as they relate to generational cohort characteristics.

A supervisor's generational characteristics may have an effect on a variety of factors, including how they manage, interact, support, and guide his/her employees. In addition, an assessment of the job satisfaction of unit supervisors may give insights into interactions and perceptions of county Extension faculty.

- Conduct personality testing of county faculty and compare these results with job satisfaction and the Herzberg Hygiene-Motivator factors.

When interviewed, some supervisors said they perceived their experiences with county Extension faculty job satisfactions factors were more based on personality type than on generational cohort or tenure status. Additional analysis of personality type and the Herzberg Hygiene-Motivator factors could provide insight on the type of individual to recruit to work for Extension, or provide greater insight when working to promote increased job satisfaction.

- Conduct the research described in this dissertation with traditional faculty, and then compare results with county Extension faculty.

This would provide an opportunity to compare job satisfaction of Extension faculty with nonExtension faculty using generational cohorts and tenure status as the independent variables. This comparison would provide an increased understanding of differences and similarities between traditional faculty and off-campus county Extension faculty at the same university. 
- Expand the research to include additional Extension systems.

Due to the small sample size of this study of county Extension faculty at one land-grant institution, expand the research to include additional Extension systems. This would allow comparison can be made across Extension systems.

- Conduct longitudinal studies of job satisfaction of employees based upon age and compare with generational cohorts job satisfaction scores.

A longitudinal study would allow an opportunity to learn whether overall, intrinsic, and extrinsic job satisfaction changes as employees' age regardless of which generational cohort they fall under.

- Identify and study job satisfaction among other Extension cohorts.

For example a study might be done with new employees versus long-term employees. Another study might look at older employees who have worked for the Extension system at different times during their careers, such as lifetime careers in Extension verses late life careers. These comparisons would provide increased knowledge of job satisfaction of different work cohorts.

\section{Conclusion}

Overall job satisfaction among county-based Extension faculty is positive. No county Extension faculty stated they were dissatisfied with their job satisfaction. Extension faculty are more intrinsically motivated than extrinsically motivated. There is a correlation between the overall level of job satisfaction of county Extension faculty, and intrinsic and extrinsic job satisfaction factors. There is also a significant relationship between job satisfaction and recognition, and job satisfaction and supervision. Statistically there are no differences between generational cohorts and faculty tenure status on job satisfaction, intrinsic job satisfaction, and 
extrinsic job satisfaction. Qualitative differences between generational cohort and tenure status were found on intrinsic and extrinsic job satisfaction. 


\section{REFERENCES}

Agriculture, W.Va. State Ann. 19-8-1 § 19-8-1 (2012).

Amend, E. H. (1970). Supervision: Motivating not controlling. Journal of Extension, 8(4). Retrieved from http://www.joe.org/joe/1970winter/1970-4-a2.pdf

August, L. \& Waltman, J. (2004). Culture, climate, and contribution: Career satisfaction among female faculty. Research in Higher Education, 45(2), 177-192.

Bandura, A. (1977). Social learning theory. Englewood Cliffs, NJ: Prentice-Hall.

Bazeley, P. (2009). Qualitative data analysis with Nvivo. Thousand Oaks, CA: Sage.

Bliss, R. K., Symons, T. B., Wilson, M. L., Gallup, G., Reese, M. J., \& Schruben, L. M. (1954). The spirit and philosophy of Extension work. Washington, D. C.: Graduate School, United States Department of Agriculture and the Epsilon Sigma Phi, National Honorary Extension Fraternity.

Boltes, B. V., Lippke, L. A., \& Gregory, E. (1995). Employee satisfaction in Extension: A Texas study. Journal of Extension, 33(5). Retrieved from http: //www.joe.org/joe/1995october/rb1.php

Bowen, C. F., Radhakrishna, R., \& Keyser, R. (1994). Job satisfaction and commitment of 4-H agents. Journal of Extension, 32(1). Retrieved from http://www.joe.org/joe/1994june/rb2.html

Boyer, E. (1990). Scholarship reconsidered. Princeton, N.J.: Carnegie Foundation for the Advancement of Teaching.

Bradley, L., Driscoll, E., \& Bardon, R. (2012). Removing the tension from Extension. Journal of Extension, 50(2). Retrieved from http://www.joe.org/joe/2012april/ttlp.shtml

Brawer, J., Steinert, Y., St-Cyr, J. Watters, K. \& Dauphinee, S. W. (2006). The significance and impact of a teaching award: Disparate perceptions of department chairs and award recipients. Medical Teacher, 28(7), 614-617. doi: 10.1080/01421590600878051

Brodeur, C. W., Higgins, C. Galindo-Gonzalez, S., Craig, D. D., \& Haile, T. (2011).

Designing a competency-based new county Extension personnel training program: A novel approach. Journal of Extension, 49(3). Retrieved from

http://www.joe.org/joe/2011june/a2.php

Castillo, J. X. \& Cano, J. (2004). Factors explaining job satisfaction among faculty. Journal of Agricultural Education, 45(3). Retrieved from http://pubs.aged.tamu.edu/jae/pdf/Vol45/4503-065.pdf?origin=publication_detail 
Cennamo, L. \& Gardner, D. (2008). Generational differences in work values, outcomes and person-organisation values fit. Journal of Managerial Psychology, 23(8), 891-906. doi: $10-1108 / 02683940810904385$

Chandler, G. D. (2004). Organizational and individual factors related to retention of county Extension agents employed by Texas Cooperative Extension. (Doctoral dissertation). Retrieved from ProQuest Dissertations and Theses database. (UMI No. 3157047)

Chronicle of Higher Education (2011). Average faculty salaries by field and rank at 4-year colleges and universities, 2010-11. Retried from http://chronicle.com/article/AverageFaculty-Salaries-by/126586/

Clegg, D. O. (1967). Motivation theory in practice. Journal of Extension, 5(1). Retrieved from http://www.joe.org/joe/1967spring/1967-1-a3.pdf

Cochran, G. Ferrrari, T. \& Chen, C. (2012). Trends affecting Ohio State University Extension in the $21^{\text {st }}$ century and the implications for human capital. Journal of Agricultural Education, 53(2). Retrieved from http://www.jaeonline.org.www.libproxy.wvu.edu/attachments/article/1669/53.2.43\%20Cochran.pdf

Cooper, A. W. \& Graham, D. L. (2001). Competencies needed to be successful county agents and county supervisors. Journal of Extension, 39(1). Retrieved from http://www.joe.org/joe/2001february/rb3.php

Cordeniz, J. A. (2002). Recruitment, retention, and management of generation X: A focus on nursing professionals. Journal of Healthcare Management, 47(4), 237-249.

Crellin, M. A. (2010). The future of shared governance. New Directions for Higher Education, 151, 71-81. doi: 10.1002/he.402

Creswell, J. W. (2009). Research design: Qualitative, quantitative, and mixed methods Approaches. Thousand Oaks, CA: Sage.

Crow, M. \& Stichnote, L. (2010). The new centurions. Power and Energy Magazine, 8(4), 2026. doi: 10.1109/MPE.2010.937124

Del Favero, M. (2003). Faculty-administrator relationships as integral to high-performing governance systems. American Behavioral Scientist, 46(7), 902-922. doi: $10.1177 / 0002764202250119$

Denzin, N. K. \& Lincoln, Y. S. (1992). Collecting and interpreting qualitative materials. Thousand Oaks, CA: Sage.

Deutskens, E., Ruyter, K. D., Wetzels, M. \& Oosterveld, P. (2004). Response rate and response quality of internet-based surveys: An experimental study. Marketing Letters, 15(1), 21-36. 
Elizer, A. H. (2010). An examination of the relationship between Tennessee County Extension Agents' job satisfaction and their perceptions of the leadership style of their Extension directors. (Doctoral dissertation). Retrieved from ProQuest Dissertations and Theses database. (UMI No. 3443000)

Enfield, R. P., Schmitt-McQuitty, L., \& Smith, M. H. (2007). The development and evaluation of experiential learning workshops for 4-H volunteers. Journal of Extension, 45(1). Retrieved from http://www.joe.org/joe/2007february/a2.php

Ensle, K. M. (2005). Burnout: How does Extension balance job and family? Journal of Extension, 43(3). Retrieved from http://www.joe.org/joe/2005june/a5.php

eXtension (2013). eXtension: About. Retrieved from http://www.extension.org/main/about

Extension Committee on Organization and Policy's Leadership Advisory Council(2005). 2005 Report. Washington, D.C.: National Association of State Universities and Land-Grant Colleges.

Extension Committee on Organization and Policy Leadership Advisory Council (2010). 2010 strategic opportunities for Cooperative Extension. Retrieved September 1, 2012, from http://www.aplu.org/document.doc?id=2019

Fetsch, R. J., \&. Kennington, M. S. (1997). Balancing work and family in Cooperative Extension: History, effective programs, and future directions. Journal ofExtension,35(1). Retrieved from http://www.joe.org/joe/1997february/a2.html

Finch, J. H., Allen, R. S. \& Weeks, H. S. (2010). The salary premium required for replacing management faculty: Evidence from a national survey. Journal of Education for Business, 85(5), 264-267. doi: 10.1080/08832320903449576

Flick, U. (1992). Triangulation revisited: Strategy of validation or alternative? Journal for the Theory of Social Behavior, 22, 175-198.

Fox, J. \& Cater, M. (2011). Participatory evaluation: Factors to consider when involving youth. Journal of Extension, 49(2). Retrieved from http://www.joe.org/joe/2011april/tt2.php

Gorard, S., \& Taylor, C. (2004). Combining methods in education and social research. Conducting educational research. Maidenhead: McGraw-Hill Education Blacklick.

Harry, B., Sturges, K. M., \& Klingner, J. K. (2005). Mapping the process: An exemplar of process and challenge in grounded theory analysis. Educational Researcher, 34(2), 3-13. doi: $10.3102 / 0013189 X 034002003$

Hass, L. W. (2002). Communication preferences and job satisfaction levels of North Carolina Cooperative Extension faculty. (Doctoral dissertation). Retrieved from ProQuest Dissertations and Theses database. (UMI No. 3073322) 
Hepworth, D. H., \& Larson, J. (1993). Direct social work practice: Theory and skills (5th ed.). Belmont, CA: Wadsworth, Inc.

Herzberg, F. (1966). Work and the nature of man. Cleveland, OH: World Publishing Company.

Herzberg, F. (2003). One more time: How do you motivate employees? Harvard Business Review, 81(1), 87-96.

Hinkle, N. C., Sparks, B., Mason, L. J., \& Vail, K. M. (2003). Extension entomology. Encyclopedia of Insects, 390.

Howe, N. \& Strauss, W. (2000). Millennials rising: The next great generation. NY, New York: Vintage books.

Hurtado, S., Eagan, K., Pryor, J. H., Whang, H., \& Tran, S. (2012). Undergraduate teaching faculty: The 2010-2011 HERI faculty survey. Retrieved from Higher Education Research Institute at UCLA website: http://www.heri.ucla.edu/monographs/HERI-FAC2011-Monograph.pdf

June, A. W. (2012, July 20). Denied tenure, a professor takes his battle public. Chronicle of Higher Education. Retrieved from http://web.ebscohost.com.www.libproxy.wvu.edu/ehost/detail?sid=6673f3d0-a0a5-45c5bae2-13a1d2e426e5\%40sessionmgr111\&vid=21\&hid=111\&bdata $=$ JnNpdGU9ZWhvc3QtbGl2ZQ\%3d\%3d\#db=a9h\&AN=78328956

June, A. W. \& Mangan, K. (2011, July 15). Efforts to measure faculty workload don't add up. Chronicle of Higher Education. Retrieved from http://web.ebscohost.com.www.libproxy.wvu.edu/ehost/detail?sid=ace17fd2-db46-475fb5f9-0299d2833033\%40sessionmgr112\&vid=7\&hid=111\&bdata= JnNpdGU9ZWhvc3QtbGl2ZQ\%3d\%3d\#db=a9h\&AN=64309199

Knapp, L.G., Kelly-Reid, J.E., \& Ginder, S.A. (2009). Employees in Postsecondary Institutions, Fall 2008, and Salaries of Full-Time Traditional Staff, 2008-09 (NCES 2010-165). National Center for Education Statistics, Institute of Education Sciences, U.S. Department of Education. Washington, DC. Retrieved from http://nces.ed.gov/pubs2010/2010165.pdf

Knapp, L.G., Kelly-Reid, J.E., \& Ginder, S.A. (2011). Employees in Postsecondary Institutions, Fall 2010, and Salaries of Full-Time Traditional Staff, 2010-11 (NCES 2012276). U.S. Department of Education. Washington, DC: National Center for Education Statistics. Retrieved from http://nces.ed.gov/pubsearch 
Kroth, M. \& Peutz, J. (2011). Workplace issues in Extension-A Delphi study of Extension educators. Journal of Extension,49(1). Available at: http://www.joe.org/joe/2011february/pdf/JOE_v49_1rb1.pdf

Krueger, R.A. \& Casey, M.A. (2000). Focus groups: A practical guide for applied research (3rd ed.). Thousand Oaks, CA: Sage Publications.

Kutilek, L. M. (2000). Learning from those who leave. Journal of Extension,38(3). Available at: http://joe.org/joe/2000june/iw2.html

Kutilek, L. Conklin, N., \& Gunderson, G. (2002). Investing in the future: Addressing work/life issues of employees. Journal of Extension, 40(1). Retrieved from http://www.joe.org/joe/2002february/a6.php

Kupperschmidt, B. R. (2000). Multigenerational employees: Strategies for effective management. The Health Care Manager, 19(1), 65-76.

Ladewig, H., \& Rohs, F. R. (2000). Southern Extension Leadership Development: Leadership development for a learning organization. Journal of Extension 38(3). Retrieved from http://www.joe.org/joe/2000june/a2.html

LaMuth, J. E. (2005). A comparison of formal and non-formal managers within Ohio State University Extension: An examination of self-efficacy, training choices, and job satisfaction. (Doctoral dissertation). Retrieved from ProQuest Dissertations and Theses database. (UMI No. 3197885)

Land-Grant Impacts (2013). Excellence in Extension personnel data. Retrieved from http://landgrantimpacts.tamu.edu/extension/excellence-in-extension/ext-cmm

Langland, E. (2011). Shared governance in an age of change. Pedagogy, 11(3), 554-562. doi: $10.1215 / 15314200-1302786$

Lechuga, V. (2011). Faculty-graduate student mentoring relationships: Mentors' perceived roles and responsibilities. Higher Education, 62(6), 757-771. doi: 10.1007/s10734-011-9416-0

Luchs, C., Seymoure, S., \& Smith, W. (2012). How important is service in the promotion and tenure process? Research in Higher Education, 15, 1-11.

Lyons, S. (2004) An exploration of generational values in life and at work. (Doctoral dissertation). Retrieved from ProQuest Dissertations and Theses database. (UMI No. 3496863)

Manathunga, C. (2012). Supervisors watching supervisors: The deconstructive possibilities and tensions of team supervision. Australian Universities' Review, 54(1), 29-37. 
Mannheim, K. (1952). The problem of generations. In P. Kecskemeti (Ed.), Essays on the sociology of knowledge. London: Routledge \& Kegan Paul.

Marlin, N. A. (2012). Myth: Faculty members are underworked and overpaid. Presidency, 15(1), 20-22.

Marston, C. (2007). Motivating the "What's in it for me?" workforce. Hoboken, NJ.: John Wiley \& Sons.

Martenson, D. (2002). Creating the base for Extension priority issues. Journal of Extension, 40(5). Retrieved from http://www.joe.org/joe/2002october/iw1.php

McDowell, G. R. (2001). Land-grant universities and Extension into the $21^{\text {st }}$ century: Renegotiating or abandoning a social contract. Ames, IA: Iowa State University Press.

Melguizo, T. \& Strober, M. H. (2007). Faculty salaries and the maximization of prestige. Research in Higher Education, 48(6), 633-668. doi: 10.1007/s11162-006-9045-0

National Center for Digest Statistics (2012). Digest of education statistics 2012. Available at website: http://nces.ed.gov/pubs2014/2014015.pdf

Nestor, P. I., \& Leary, P. (2000). The relationship between tenure and non-tenure track status of Extension faculty and job satisfaction. Journal of Extension, 38(4). Retrieved from http://www.joe.org/joe/2000august/rb1.html

Nichols, A. (2004). The effect of tenure and promotion policy on evaluation and research in Extension. Journal of Extension, 42(2). Retrieved from http://www.joe.org/joe/2004april/rb1.php

Nir, A. E., \& Zilberstein-Levy, R. (2006). Planning for academic excellence: Tenure and professional considerations. Studies in Higher Education, 31(5), 537-554. doi: 10.1080/03075070600922725

Olsen, S. (2005). County agents and university tenure and promotion systems. Journal of Extension, 43(3). Retrieved from http://www.joe.org/joe/2005june/rb5.php

O'Meara, K. (2006). Encouraging multiple forms of scholarship in faculty reward systems: Have academic cultures really changed? New Directions for Institutional Research, 129, 77-95. doi: 10.1002/ir.173

Patton, M. Q. (1988). Extension's future: Beyond technology transfer. Knowledge: Creation, Diffusion, Utilization 9(4), 476-491. doi: 10.1177/0164025988009004002

Parry, E. \& Urwin, P. (2010). Generational differences in work values: A review of theory and evidence. International Journal of Management Reviews, 13(1), 79-96. doi: 10.1111/j.1468-2370.2010.00285.x 
Peters, S. J. (2002). Rousing the people of the land: The roots of the educational organizing tradition in Extension work. Journal of Extension, 40(3). Retrieved from http://www.joe.org/joe/2002june/a1.php

Place, N. T. \& Jacob, S. (2001). Stress: Professional development needs of Extension faculty. Journal of Agricultural Education, 42(1), 96-104. doi: 10.5032/jae.2001.01096

Ponjuan, L., Conley, V. M., \& Trower, C. (2011). Career stage differences in pre-tenure track faculty perceptions of professional and personal relationships with colleagues. The Journal of Higher Education, 82(3), 319-346. doi: 10.1353/jhe.2011.0015

Raison, B. (2010). Educators or facilitators? Clarifying Extension's role in the emerging local food systems movement. Journal of Extension, 40(5). Retrieved from http://www.joe.org/joe/2010june/comm1.php

Riggs, K., \& Beus, K. M. (1993). Job satisfaction in Extension. Journal of Extension, 31(2). Retrieved from http://www.joe.org/joe/1993summer/a5.html

Rhodes, S. (1983). Age-related differences in work attitudes and behavior: A review and conceptual analysis. Psychological Bulletin, 93(2), 328-367. doi: 10.1037/0033-2909.93.2.328

Roberts, C. M. (2004). The dissertation journal: A practical and comprehensive guide to planning, writing, and defending your dissertation. Thousand Oaks, CA: Sage.

Roberts, C., \& Lang, K. (1985). Generations and ideological change: Some observations. Public Opinion Quarterly, 49(4), 460-473.

Rousan, L. M., \& Henderson, J. L. (1996). Agent turnover in Ohio State University Extension. Journal of Agricultural Education, 37(2). Available at: http://www.jaeonline.org/attachments/article/568/37-02-56.pdf

Ruggett, J., \& Chemosit, C. C. (2009). What motivates students to learn? Contribution of student-to-student relations, student-faculty interaction and critical thinking skills. Educational Research Quarterly, 32(3), 16-28.

Safrit, R. D., \& Owen M. B. (2010). A conceptual model for retaining county extension program professionals. Journal of Extension, 48(2). Retrieved from http://www.joe.org/joe/2010april/a2.php

Smith-Lever Act , 7 U.S.C. § 341 et seq. (1914).

Smola, K. W., \& Sutton, C. D. (2002). Generational differences: Revisiting generational 
work values for the new millennium. Journal of Organizational Behavior, 23(4), 363-382. doi: $10.10002 /$ job. 147

Stark, C. B. (2011). The relationship among workload, job satisfaction, and burnout of Extension 4-H youth development professionals from six land-grant universities. (Doctoral dissertation). Retrieved from ProQuest Dissertations and Theses database. (UMI No. 3492416)

Strauss, A. \& Corbin, J. (1990). Basics of qualitative research: Grounded theory and procedures and techniques. Newbury Park, CA: Sage Publications.

Strong, R. and Harder, A. (2009). Implications of maintenance and motivation factors on Extension agent turnover. Journal of Extension, 47(1). Retrieved from http://www.joe.org/joe/2009february/a2.php

Stumpf, M. N. (2003). The relationship of perceived leadership styles of North Carolina County Extension Directors' to job satisfaction of county Extension professionals. (Doctoral dissertation). Retrieved from ProQuest Dissertations and Theses database. (UMI No. 3099023)

Torock, J. L. (2009). Experiential learning and Cooperative Extension: Partners in nonformal education for a century and beyond. Journal of Extension, 47(6). Retrieved from http://www.joe.org/joe/2009december/tt2.php

Twenge, J. M., \& Campbell, S. M. (2008). Generational differences in psychological traits and their impact on the workplace. Journal of Managerial Psychology, 23(8), 862-877. doi: $10.1108 / 02683940810904367$

Twenge, J. M. (2010). A review of the empirical evidence on generational differences in work attitudes. Journal of Business and Psychology, 25(2), 201-210. doi: 10.1007/s10869-0109165-6

United States Department of Agriculture (2011). National Institute of Food and Agriculture: About us. Retrieved from http://nifa.usda.gov/qlinks/extension.html

United States Bureau of Labor Statistics. (2010). Median years of tenure with current Employer for employed wage and salary workers by age and sex, selected years, 1996-2008. Retrieved from http://www.bls.gov/news.release/tenure.t01.htm

Utz Jr., A. P. (1965). Agent performance in programming. Journal of Extension, 3(3). Retrieved from http://www.joe.org/joe/1965fall/1965-3-a4.pdf

Varner, D. L. (2011). A phenomenological study of Millennial generation Cooperative 
Extension educators' development of core competencies. (Doctoral dissertation). Retrieved from ProQuest Dissertations and Theses database. (UMI No. 3466260)

Weiser, C. J. \& Houglum, L. (1998). Scholarship unbound for the $21^{\text {st }}$ century. Journal of Extension, 36(4). Retrieved from http://www.joe.org/joe/1998august/a1.php

Weiss, D. J., Davis, R. V., England, G. W., \& Lofquist, L. H. (1967). Manual for the Minnesota Satisfaction Questionnaire (Minnesota Studies in Vocational Rehabilitation No. 22). Minneapolis, MN: University of Minnesota, Industrial Relations Center.

Weston, M. (2001). Coaching generations in the workplace. Nursing Administration Quarterly, 25(2), 11-21.

West Virginia State University (n.d.). West Virginia State University history. Retrieved March 10, 2013 from http://www.wvstateu.edu/Land-Grant/History.aspx

West Virginia University (2011). West Virginia University mission. Retrieved March 10, 2013 from http://strategicplan.wvu.edu/the_map/mission

West Virginia University Extension Service (2012, September). The WVU Extension Service Organization. Retrieved on February 13, 2013 from http://employees.ext.wvu.edu/r/download/140916

West Virginia University Extension Service (n.d.). Work Scheduling Guidelines for Employees in Exempt Positions. Retrieved on April 25, 2014 from http://humanresrouces.ext.wvu.edu/r/download/36719

Wong, M., Gardiner, E., Lang, W. \& Couon, L. (2008). Generational differences in personality and motivation: Do they exist and what are the implications for the workplace? Journal of Managerial Psychology, 23(8), 878-890. doi: 10.1108/02683940810904376

Young, T. I. \& Price, T. M. (2009). Learning from the experience of others: The evolution of faculty tenure and promotion rules in comprehensive institutions. The Journal of Higher Education, 80(2), 204-237. 
APPENDIX A: Institutional Review Board Approval 


\section{WestVirginiaUniversity.}

Orfice of Research Integrity and Compliance

\section{Acknowledgement Letter Exempt Initial Protocol Review}

To

From

Approval Period

Subject

Protocol Tracking

Title
Lauryl Lefebvre

WVU Office of Research Integrity and Compliance

12/04/2013 Expiration Date 12/03/2016

Acknowledgement Letter Exempt Initial Protocol Review

1308070890

An Examination of Job Satisfaction Related to Generational Cohorts and Faculty Status of West Vurginia University Extension Service County Faculty

The above-referenced study was reviewed by the West Virginia University Institutional Review Board IRB and was granted exemption in accordance with 45 CFR 46.101.

- This research study was granted an exemption because the Research involves educational tests, survey procedures, interview procedures or observation of public behavior and (i) information obtained is recorded in such a manner that human subjects cannot be identified, directly or through identifiers linked to the subjects; and (ii) any disclosure of the human subjects responses outside the research could not reasonably place the subjects at risk of criminal or civil liability or be damaging to the subjects financial standing, employability, or reputation [45 CFR 46.101(2)]. All exemptions are only good for three years. If this research extends more than three years beyond the approved date, then the researcher will have to request another exemption. The following documents have been acknowledged for use in this study and are available in the WVU+kc system:

Documents for use in this study have been acknowledged and validated and are available in the WVUkc system in the Notes and Attachments section of your protocol.

If you have any questions, please contact the IRB at 3042937073.

Thank you.

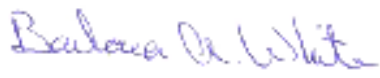

Board Designee Barbara White 
APPENDIX B: Online Questionnaire 


\section{Minnesota Satisfaction Questionnaire}

\section{Minnesota Satisfaction Questionnaire}

The purpose of this questionnaire is to give you a chance to tell how you feel about your present job. what things you are satisfied with and what things you ere not satisfied with.

On the basis of your answers and those of pecple like you, the hope is to get a beller understanding of the things people like and dislike aboul their jobs.

On the next poge you wili find statements about your present job.

Read each statement carefully.

Decide how satisfied you foal about the aspecl of your job doscribed by the statement.

Keeplng the statement in mind:

- if you feel that your job gives you more than you expected, check the box under "Very Sat. ' Very Satisfied):

- if you feel that your job gives you what you expected, check the box under "Sat." (Satisfied):

- if you cannot make up your mind whether or not the jod gives you what you expacted, check the box under "N" (Neither Satistied nor Dissatisfied):

- If you feel that your job gives you less than you expectod, check the box under "Dissat." (Dissatisfied):

- if yau feel that your job gives you much less than you cxpected, check the box under "Very Dissat." (very Dissatisfied).

Remember: Keep the statoment in mind when cociding how satisfied you feel about that aspect of your job.

Do this for all stalements. Pleaso answier every item.

Be frank and honest. Give a true picture of your feelings about your presant job.

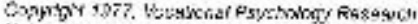

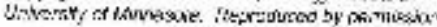

Ask yourself: How satisfied am I with this aspect of $m y$ job?

Very Satisfied - means I am very satisfied with this aspect of $m y$ job.

Satisfied - means I am satisfied with this aspect of my job.

Neutral - means I canit decide whether I am satisfied ar not with this aspect of my job.

Dissatisfled - means I am dissatisfiod with this aspect of my job. 
Qualtrics Survey Sotwas

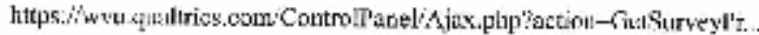

Very Dissatisfied - meuns I am very dissatisfied with this aspect of my job

\section{On my present job, this is how I fool about ...}

\begin{tabular}{|c|c|c|c|c|c|}
\hline & \multicolumn{5}{|c|}{ Responst Cprikars, } \\
\hline & $\begin{array}{c}\text { Vey } \\
\text { Desalisied }\end{array}$ & Discatistied I & Neltes: & Sat saic: & $\begin{array}{c}\text { very } \\
\text { Suhsfirat }\end{array}$ \\
\hline Bering abe lo keep Lusg all the time... & $e$ & 6 & & 0 & 3 \\
\hline The chence to woxk airsie an the jos. & $e$ & $\therefore$ & $\ominus$ & $\$$ & 8 \\
\hline 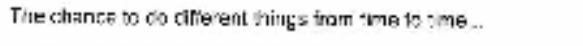 & e & c. & $c$ & 0 & 6 \\
\hline The chunoe to te somabody" in the crmm.urity... & 5 & 8 & $e$ & 6 & $\theta$ \\
\hline 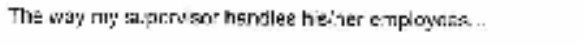 & 6 & 0 & & 0 & $\phi$ \\
\hline 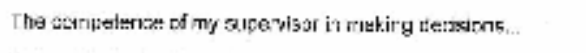 & 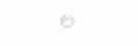 & $\odot$ & 6 & $\circ$ & $\odot$ \\
\hline Herg able to do uhings that dent ge ag a nst my tenas coce. . & 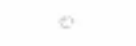 & 8 & 8 & c & e. \\
\hline The woy my ios Levides for racary cmokprien!... & e & o & e & $e$ & 2 \\
\hline Th:e chance to do thinge fer eties penph... & $\theta$ & & th & 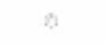 & 2) \\
\hline 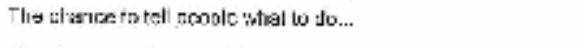 & $\theta$ & 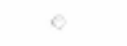 & 0 & $\theta$ & 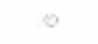 \\
\hline The chance bo ude strmuthing thet makes use of my abilitios. & $n$ & 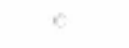 & $c$ & 5 & $e$ \\
\hline 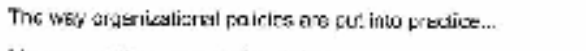 & e. & 0 & $e$ & $\theta$ & 6 \\
\hline My pay and the arrourt. of work I to... & $\odot$ & & c. & 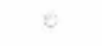 & 8 \\
\hline 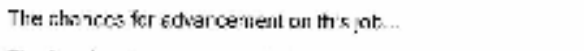 & 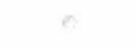 & 6 & $e$ & 8 & 3 \\
\hline The teetdeuri lo use my osn jugignent.. & f & & & 8 & 8 \\
\hline 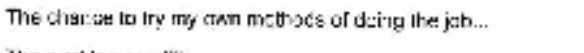 & 8 & e & 0 & 6 & $\theta$ \\
\hline Ihe vorking cordtione. & & & e & $e$ & $c$ \\
\hline The why my co-workers yes aleng wath aach wher... & 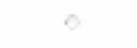 & 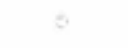 & $Q$ & 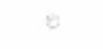 & \\
\hline The praise I gel tor delng g geed jeb... & $c$ & & 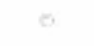 & $n$ & 8 \\
\hline The letling of acromplistmert I get fun tie joh... & es & $e$ & $\mathrm{e}$ & 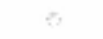 & 0 \\
\hline
\end{tabular}

County Extension Faculty Job Satisfaction Questions

County Extension Faculty Job Satisfaction Questions

in torms of imporlanca to your job, describe 3 tasks of county Exlension faculty members.

Describe your 3 major responsibilities as a county Extonsion faculty member. (Those things you are in charge of or have authority over.' 
Describe vihat you do when given neN respunsibilities.

Describe what you do when you are not given meaningful responsibilities.

Do you seek new responsibilities?

Yes

Nu

Why or why not?

What types of recognition do you reseive for your work? 
Qualtics Survey Soflware

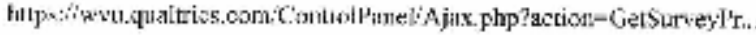

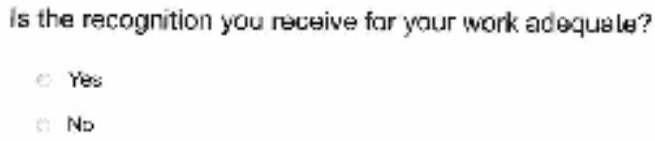

Why or why not?

Aside frum recognition, how do you know when you have acomplished (achicved) something through yourwork?

What do you like most about the promotion and tenure system?

What do you like least about the promotion and tenure sysiem?

Describe the type of supervision under which you work best. 
Qualuites Survey 5afiwate

Is tha supervision you receivo adequate?

cros

c. No

Why or why not?

How important is your salary to your job satisfaction?

Is your salary adequate?

vos

No

Why or why not?

What do you like most about the Extension structure of feceral, state, and Incal partnerships?

5 of 9

2:9/2014 3:24 PM 
What do you like least about the Extension siructure of foderal, state, and incal partnerships?

Describe an interpersonal ralationship you have had as a county Extension facully member with a client. (Interpersonal relutionship is defined as an ongoing professional interactioni.

Describe an interporsonal relationahip you have had as a county Extension faculty member with a poer. (Interpersonal relationship is defined as an engcing professional interaction).

Describe an intorpersonal relationship you have had as an Extension faculty member with your supervisor. (Intamersonal relationship is tefined as an ongoing professional interaction!.

Descrlbe what you like most about your work uonditions as a county Extension faculty member. 
Describe what you like least about your work conditions as a county Extension faculty member.

\section{Demographics}

\section{Demographics}

What is your gender?

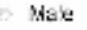

What time period were you born?
- Balcre :94e
ㄷ. 1946-18E:
ค. เดงt-1979
(7) $1880 \cdot 2030$

Do you have tenure?

YeE

No 


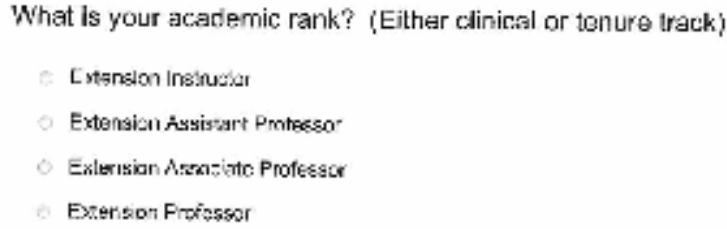

In ardition to toaching, what is your second area of significance?

6) Servix

C) Reswarch

What is your primary program area?

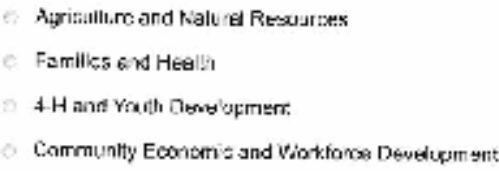

Which other program areas do you serve? (Chexk s! that appy.;

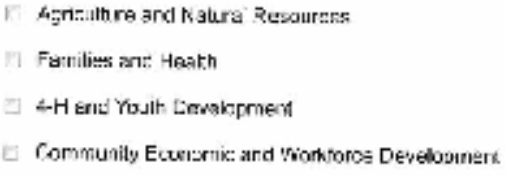

Number of years working for the Extension Service. (whole number only i.e, 20) 
Average number af haurs you work in a typical wook. (whole number only i.e. 40)

Average number of overnights away from home per year. (whole number only i.e. 10)

Average number of direct contacis per year. (whole number only i.e. 100). (Dircet conlact defined as individuals with whorn you interact i.e. through phone calls, workshops, or saminers. Does not include mass media.)

Number of people you supervise. (vihole number only i.c. 2)

Percent of ame spent per year in each eres. (whole number only i.e, 30 for 30 percent, total must equal 100)

Teachne

0

Resagrch

serice

Tatal

Rate how your personal responsibilities outside of work impact your job responsibilities.
A. 1 erge in $06 \mathrm{c}$
Same mpect
No Impsel 
APPENDIX C: Supervisor Interview Questions 
Supervisor Interview Questions

First, let me ask you a few questions about yourself.

1. How many years have you been a unit supervisor?

2. How many county Extension faculty members do you supervise?

3. In which of the following time periods were you born?
a. Before 1946
b. $1946-1964$
c. $1965-1979$
d. $1980-2000$

Next, I am going to ask you questions about differences in Extension faculty based on their generational group. We will be differentiating between four generational groups.

- Pre-baby Boomers - 68 or older

- Baby Boomers -- $49-67$

- Generation X -- $34-48$

- Millenials -- $22-33$

4. Describe the differences you see in how Extension faculty from the four generational groups do each of the following:

a. Handle the tasks of their job

b. Accept new job responsibilities

c. Desired types of recognition

d. Perceive achievements in their work (not recognition for their work)

e. Place importance on advancement through the promotion and tenure system

f. Types of supervision needed or wanted

g. Importance placed on salary

h. Regard policy and administration of the Extension structure of federal, state, and local partnerships

i. Interact with their supervisor (you)

j. Interact with peers 
k. Interact with clients

1. Regard working conditions

m. Assess overall job satisfaction

Now we are going to talk about the differences in Extension faculty based on whether they have received promotion and tenure yet (faculty with tenure and non-tenures status).

5. Describe the differences you see in how Extension faculty with tenure and non-tenure status:

a. Handle the tasks of their job

b. Accept new job responsibilities

c. Desired types of recognition

d. Perceive achievements in their work (not recognition for their work)

e. Place importance on advancement through the promotion and tenure system

f. Types of supervision needed or wanted

g. Importance placed on salary

h. Regard policy and administration of the Extension structure of federal, state, and local partnerships

i. Interact with their supervisor (you)

j. Interact with peers

k. Interact with clients

1. Regard working conditions

m. Assess overall job satisfaction 
APPENDIX D: Permission to Use Minnesota Satisfaction Questionnaire (MSQ)

Short-Form 
UnIVERSITY OF MinNESOTA

Twin Cities Campus

Department of Psychology

N218 Elliott Hall

75 East River Road

Minneapolis, MN 55455

Office: $612-625-2818$

Fax: 612-626-2079
www psych.umn.edu

September 3, 2013

Susan Gamble

102 Oakview Lane

Beckley, WV 25801

Dear Susan Gamble:

We are pleased to grant you permission to use the Minnesota Satisfaction Questionnaire 120 MSQ Short form with the modifications requested on a secure web site as you requested for your research. We acknowledge receipt payment for Royalty fees for 120 MSQ Short form surveys.

Please note that each copy that you make must include the following copyright statement:

Copyright 1977, Vocational Psychology Research

University of Minnesota. Reproduced by permission.

We would appreciate receiving a copy of any publications that result from your use of the MSQ Short form. We attempt to maintain an archive and bibliography of research related to Vocational Psychology Research instruments, and we would value your contribution to our collection.

If you have any questions, or if we can be of any additional assistance, please do not hesitate to contact us.

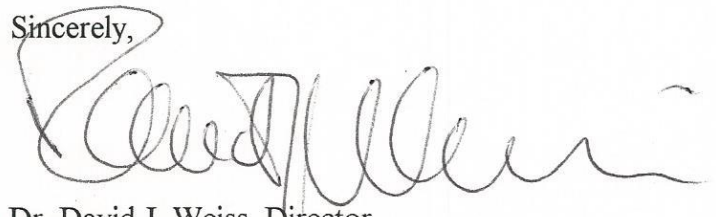

Dr. David J. Weiss, Director

Vocational Psychology Research

\section{Driven to Discover ${ }^{\text {sM }}$}


APPENDIX E: County-Based Faculty Cover Letter 
Dear <First Name>,

I am asking you to complete a research questionnaire to explore job satisfaction of WVU Extension Service county-based Extension faculty related to generational cohorts and faculty status. This project is being completed under the supervision of Dr. Lauryl Lefebvre, assistant professor in the College of Education and Human Services, in order to fulfill the requirements for the degree of Doctor of Education in Higher Education Administration. West Virginia University's Institutional Review Board's approval of this project is on file in the Office of Research Compliance.

Your participation is completely voluntary. You may skip any question that you do not wish to answer, and you may discontinue completing the survey at any time. It will take approximately 30 minutes to complete the online questionnaire. Your responses to the questionnaire will be anonymous and confidential. You will not be asked any information that identifies you as a participant and IP addresses will be scrubbed when your responses are saved in the questionnaire by Qualtrics, a password protected computer program. All data will be reported in the aggregate.

I hope that you will participate in this research project, as it could be beneficial in understanding the job satisfaction of county-based Extension faculty members. Should you have any questions about this letter or the research project, please contact me at (304) 255-9375 or by e-mail at skgamble@mail.wvu.edu.

Your time and help with this project is greatly appreciated. In order to respond to the questionnaire please go to the following link http://wvu.qualtrics.com/SE/?SID=SV 4H3hl6V71/76rKR

Thank you, Susan Gamble 
APPENDIX F: Supervisor Cover Letter 
Dear WVU Extension Service Unit Director,

I am asking you participate in a research study to explore job satisfaction of WVU Extension Service county-based Extension faculty related to generational cohorts and faculty status. This project is being completed under the supervision of Dr. Lauryl Lefebvre, assistant professor in the College of Education and Human Services, in order to fulfill the requirements for the degree of Doctor of Education in Higher Education Administration. West Virginia University's Institutional Review Board's approval of this project is on file in the Office of Research Compliance.

Your participation is completely voluntary. You may skip any question that you do not wish to answer, and you may discontinue the interview at any time. It will take approximately 30 to 45 minutes to complete the interview. Your responses in the interview will be confidential, and the data collected from the interview will be analyzed and reported in the aggregate. Your standing as a faculty member will not be affected by not participating in the interview.

I hope that you will participate in this research project, as it could be beneficial in understanding the job satisfaction of county-based Extension faculty members. Should you have any questions about this letter or the research project, please feel free to contact me at (304) 255-9375 or by e-mail at skgamble@mail.wvu.edu.

Your time and help with this project is greatly appreciated.

Thank you, Susan Gamble 
APPENDIX G: Cognitive Review Results 


\section{Cognitive Review Results}

\section{Procedure}

The on-line questionnaire of demographic and open-ended questions underwent cognitive review with Extension personnel in other states to ensure that the questions measure concepts familiar to the research subjects. Extension faculty completed the review at Galaxy IV, a national conference for Extension educators in Pittsburgh, PA in September 2013. The conference, which is held every five years by the Joint Council of Extension Professionals (JCEP), provides professional development for the entire Extension System. Ten individuals working in the areas of 4-H youth development; community, economic and workforce development; and family consumer sciences completed the cognitive review. These individuals were from the following states: Florida, Indiana, New York, Ohio, Oklahoma, Pennsylvania, and Wyoming.

The purpose of the review was to assess if the county faculty online questionnaire in Qualtrics was easy to access, easily understood, and measured what it was designed to measure. The purpose was also to determine if any modifications were needed. The researcher randomly approached individuals at the Galaxy IV conference verbally explaining the research, the purpose of the cognitive review, and asking for their willingness to participate. These Extension educators were asked to read the instructions and review all of the questions for clarity. They were then provided a second questionnaire in Qualtrics to provide responses and give feedback. Adjustments have been made as a result of the participants' responses. Individuals were not asked to complete MSQ questionnaire as this is a licensed survey which will be used as designed without changes. 


\section{Results}

In regards to questions of format, use, and layout, the Qualtrics web-based survey received a positive response from respondents. Overwhelmingly the respondents marked that the survey opened quickly and easily. Respondents remarked that the format was appealing and easy to follow and that they easily understood where to place their answers. One respondent commented that he/she liked having the demographic questions at the end of the survey.

When respondents were asked whether any questions or words were not easily understood or did not make sense, two areas were identified: 1) clarification on the question about the number of direct contacts, and 2) questions related to significant interpersonal relationships. A better understanding of the term, "direct contacts," should be provided, and respondents need information on how to count direct contacts. There was also some confusion about the phrase "significant interpersonal relationships." It needs to be defined and clarified.

When respondents were asked whether they had any additional suggestions for improvement to the questionnaire, six of the ten respondents remarked that no improvements were needed. One individual recommended changing the academic rank titles, but that will not be necessary since this questionnaire will only be used with faculty at West Virginia University. One recommended a better introduction about the topic of the survey. This will be more clearly outlined by the cover letter that will be emailed with the questionnaire to the West Virginia University county Extension faculty.

The primary concern respondents had was that the survey was too long. One respondent noted that it took her 45 minutes to complete the survey. One suggested providing more guidance to some open-ended questions, for example the question, "How would you describe the 
work or tasks of county Extension faculty?" might include a list of five tasks to choose from, rather than leaving the question open-ended.

The cognitive review of the questionnaire was extremely beneficial in receiving feedback on the pros and cons of the tool. Suggestions were made that are beneficial in better preparing the tool to use with county Extension faculty at West Virginia University. In addition, while the first respondent was completing the cognitive review, glitches within the setup of the Qualtrics questionnaire became apparent and were easily fixed.

\section{Recommendations}

1. Better define direct contacts.

2. Define significant interpersonal relationships

3. Review options to shorten or assure the questionnaire can be completed in a shorter amount of time. 
APPENDIX H: Qualitative Research Consultant Memo 


\title{
INTEROFFICE MEMORANDUM
}

\author{
TO: \\ SUSAN GAMBLE AND DOCTORAL COMMITTEE \\ FROM: $\quad$ DR. JACI WEBB-DEMPSEY \\ SUBJECT: $\quad$ DATA CODING AND ANALYSIS AUDIT \\ DATE: $\quad$ May 30, 2013
}

It was a pleasure to serve as an external reviewer for Susan Gamble's dissertation data. Having had Susan as a student in my Qualitative Research course while at WVU and as a long-standing colleague in Extension Service, I had familiarity with her process and the context of her research. Context is critical in the analysis of qualitative data. In this case, having served as a program specialist with Energy Express, a summer reading program supported by WVU Extension Service for 3 years I understand the context of Susan's study. In my role with Energy Express, I worked with county and state agents on delivery and support for the program and with their supervisors. I also provided leadership to program evaluation efforts and a multi-agent qualitative study of the impact of Energy Express participation on K5 students and college student mentors. Having participated in the regularities of the annual schedule including annual review and annual meeting - I have "native" knowledge of the work of Extension agents and their roles and responsibilities both in their counties and in the state office.

Susan provided me with access to her raw data, as managed in NVivo, her data tables, her code book, and the results of her preliminary and final analyses. Data analysis and reduction followed the basic framework described by Harry, Sturges and Klinger (2005), moving from discrete preliminary codes to larger, more encompassing categorical codes, to an examination of the relationship of comprehensive codes to one another and to the factors used to frame the study, e.g. age/cultural group, tenure status, and the factors related to Herzberg's motivation-hygiene theory or theory of intrinsic/extrinsic motivation. At each step, I conducted an independent analysis and then compared my results to Susan's to verify the reliability of her process and results.

\section{Audit Results}

To begin the independent audit, I first read the prospectus for an understanding of the conceptual/theoretical framework and research design for the study. Prior to examining Susan's preliminary coding, I first conducted a holistic review of the data set, developing a list of initial emergent codes, and then I compared my results to Susan's. Here I noted that Susan's analysis "stayed close to the data" in terms of the labels she developed and that there was strong agreement between the results of our analyses at this level in terms of what constituted a code and how codes were applied across the data set.

The next step in the audit was to then review the next level of coding and data reduction in the context of the conceptual/theoretical framework. Here again there was strong agreement between the 
results of our analyses, as the nature of the survey data in particular yielded data that was organized around that framework. This coding was also organized by factors (age/cultural group, tenure status, and organizational role) and supported a more complex set of comparisons. This comparative analysis revealed that there was more agreement across factors, both within and across these groups, than disagreement or unique perspectives and/or experiences. Many of the differences appeared to be related to length of service and experience in the organization (for which tenured status could be viewed as a proxy).

For the final step in the audit, I read Susan's final analysis to examine her summarization of results and her interpretation of those results and compare that summarization and her interpretations to the coding and analysis to that point. Her summarization was very straight-forward, again she stayed close to the data and the constructs of her study in both. There appeared to be no unsupported findings or interpretations. As a final step, I informally interviewed Susan around her representation of the results of her comparative analyses (a graphic organizer displaying major themes as related to membership in age/cultural groups and tenured/non-tenured status). Susan was able to justify and clarify her summarization, citing data and aligning components with her narrative summarization.

Overall I feel comfortable verifying Susan's analytic process, results and findings.

\section{Limitations}

One limitation noted throughout the audit process was the discrepancy between the types of data collected from agents versus the data collected from their supervisors (open-ended survey data versus open-ended, semi-structured interview data respectively). This led to richer data and the potential for a deeper and more meaningful analysis of the supervisor data and made comparisons across the data set less direct. The data participants "offer up" unsolicited, either in response to very broad open-ended questions or completely unsolicited of their own volition is fundamentally different from data elicited by a survey question clearly framed around a conceptual or theoretical factor and without the opportunity to first ask very broadly and then probe to focus in on that conceptual or theoretical factor.

Another potential limitation is one that is common when the researcher is learning to use unfamiliar features of a data management and analysis software program while engaged in the study. The software Susan used is very sophisticated and robust, but not particularly intuitive easy to use without practice and professional development. Her early struggles to learn to use the software, while she clearly became proficient over the course of the study, meant she had to "redo" preliminary analyses as she became more familiar with features that would enhance data management and the generation of reports. As qualitative research is emergent and iterative, this could mean the ongoing constant comparative analysis may have been compromised, which could have influenced her final results. While I don't believe this was the case here, it is worth noting. 